\title{
Proteins with calmodulin-like domains: structures and functional roles
}

\author{
Antonio Villalobo $^{1,2} \cdot$ María González-Muñoz $\cdot$ Martin W. Berchtold ${ }^{3}$
}

Received: 19 July 2018 / Revised: 26 February 2019 / Accepted: 7 March 2019 / Published online: 15 March 2019

(c) Springer Nature Switzerland AG 2019

\begin{abstract}
The appearance of modular proteins is a widespread phenomenon during the evolution of proteins. The combinatorial arrangement of different functional and/or structural domains within a single polypeptide chain yields a wide variety of activities and regulatory properties to the modular proteins. In this review, we will discuss proteins, that in addition to their catalytic, transport, structure, localization or adaptor functions, also have segments resembling the helix-loop-helix EF-hand motifs found in $\mathrm{Ca}^{2+}$-binding proteins, such as calmodulin (CaM). These segments are denoted CaM-like domains (CaM-LDs) and play a regulatory role, making these $\mathrm{CaM}$-like proteins sensitive to $\mathrm{Ca}^{2+}$ transients within the cell, and hence are able to transduce the $\mathrm{Ca}^{2+}$ signal leading to specific cellular responses. Importantly, this arrangement allows to this group of proteins direct regulation independent of other $\mathrm{Ca}^{2+}$-sensitive sensor/transducer proteins, such as $\mathrm{CaM}$. In addition, this review also covers CaM-binding proteins, in which their CaM-binding site (CBS), in the absence of $\mathrm{CaM}$, is proposed to interact with other segments of the same protein denoted CaM-like binding site (CLBS). CLBS are important regulatory motifs, acting either by keeping these CaM-binding proteins inactive in the absence of $\mathrm{CaM}$, enhancing the stability of protein complexes and/or facilitating their dimerization via CBS/CLBS interaction. The existence of proteins containing CaM-LDs or CLBSs substantially adds to the enormous versatility and complexity of $\mathrm{Ca}^{2+} / \mathrm{CaM}$ signaling.
\end{abstract}

Keywords $\alpha$-Actinin - Calcineurin · Calpain - Epidermal growth factor receptor - Glycerol-3-phosphate dehydrogenase . NADPH oxidases $\cdot \mathrm{Na}^{+} / \mathrm{H}^{+}$exchanger $\cdot$ Plasma membrane $\mathrm{Ca}^{2+}$-ATPase $\cdot$ Protein kinases

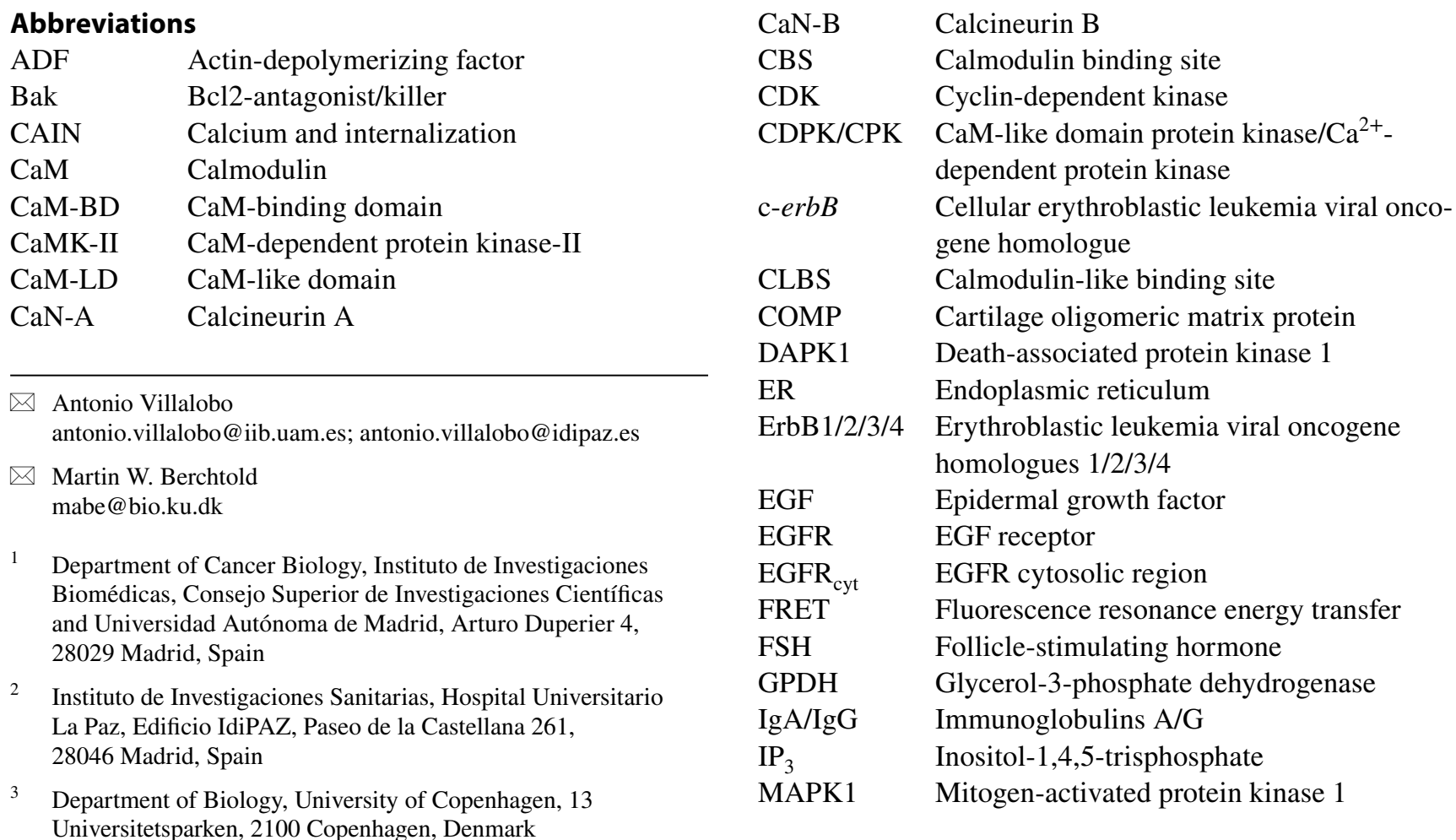




$\begin{array}{ll}\text { MLCK } & \text { Myosin light-chain kinase } \\ \text { NHE1 } & \mathrm{Na}^{+} / \mathrm{H}^{+} \text {exchanger } 1 \\ \text { NLS } & \text { Nuclear localization sequence } \\ \text { NMR } & \text { Nuclear magnetic resonance } \\ \text { NOX5 } & \text { NADPH oxidase } 5 \\ \text { ROS } & \text { Reactive oxygen species } \\ \text { LIMP-2 } & \text { Lotus intrinsic membrane protein } 2 \\ \text { PIP } 2 & \text { Phosphatidylinositol } 4,5 \text {-bisphosphate } \\ \text { PKG } & \text { cGMP-dependent protein kinase } \\ \text { PLC } \gamma & \text { Phospholipase } \mathrm{C} \gamma \\ \text { PMCA } & \text { Plasma membrane } \mathrm{Ca}^{2+} \text {-ATPase } \\ \text { SERA5 } & \text { Serine-repeat antigen 5 } \\ \text { TRP } & \text { Transient receptor potential }\end{array}$

\section{Introduction}

The calcium ion plays a fundamental signaling role in all eukaryotic organisms. The transduction of the $\mathrm{Ca}^{2+}$ signal is mostly achieved by a great variety of $\mathrm{Ca}^{2+}$-binding proteins containing helix-loop-helix EF-hand motifs. The name of this motif is derived from the $\mathrm{Ca}^{2+}$-binding sites of parvalbumin, where it was first identified [1]. It is formed by a loop of 12 amino acids rich in acidic residues, which coordinates $\mathrm{Ca}^{2+}$, and links the two $\alpha$-helical segments $\mathrm{E}$ and $\mathrm{F}$ in a perpendicular way. The phylogeny of these proteins shows an evolutionary history, in which gene duplication played a fundamental role. By this mechanism, a predicted ancient gene encoding a single EF-hand-containing protein can be seen as a precursor yielding a plethora of different proteins working as $\mathrm{Ca}^{2+}$-binding sensors and buffers [2-4]. Nevertheless, this did not occur in all cases, because events of convergent evolution took place as well $[3,4]$. The beststudied EF-hand containing protein is calmodulin $(\mathrm{CaM})$. The structure of CaM consists in two globular lobes located at the $\mathrm{N}$ - and $\mathrm{C}$-termini of the protein each containing two EF-hand $\mathrm{Ca}^{2+}$-binding sites and a flexible linker connecting both globular lobes. This structure permits the interaction of $\mathrm{CaM}$ with its targets adopting different conformations, and to work as a linker between different proteins and/or segments of the same polypeptide chain. This contributes to the dimerization of identical or different proteins, and to attain structural conformers of the target protein modulating their functionality (reviewed in [5]). CaM is universally expressed in all eukaryotic cells and interacts with several hundred enzymes, channels, and other proteins without catalytic or transport activity including transcription factors, adaptors, signaling and structural proteins, regulating a myriad of cellular functions (reviewed in [5-10]). Although CaM mainly works in a $\mathrm{Ca}^{2+}$-dependent manner, it also regulates the function of many proteins in a $\mathrm{Ca}^{2+}$-free form (apo-CaM) $[11,12]$. CaM has an identical sequence in all vertebrates but is coded from two or three independent genes, depending on the species $[13,14]$. Plants, however, express several CaM isoforms coded from different genes (for example seven in Arabidopsis) (reviewed in [15, 16]). In some cases, CaM may work as an integral component of the target proteins, rather than just interacting with them when the concentration of $\mathrm{Ca}^{2+}$ rises. This consists in the integration of $\mathrm{CaM}$ as a constitutive subunit of the functional target protein even when the $\mathrm{Ca}^{2+}$ concentration is low. Well-known examples of such proteins are phosphorylase b kinase (reviewed in [17]), the inducible nitric oxide synthase isoform (reviewed in [18]), and it has been proposed to be the case as well for some ion channels (reviewed in [19]).

Another level of complexity of $\mathrm{Ca}^{2+}$ sensors/target signaling consists of the presence of EF-hand modules in proteins that have an enzymatic, transport, adaptor or another functional domain. This enabled the proteins to be directly regulated by $\mathrm{Ca}^{2+}$ and thereby transmit the signal downstream without the need of a distinct $\mathrm{Ca}^{2+}$ sensor protein, such as $\mathrm{CaM}$ or other proteins containing EF-hand motifs. Nevertheless, there are examples, in which in addition to the direct binding of $\mathrm{Ca}^{2+}$ to the EF-hands of the CaM-like domain (CaM-LD) containing proteins, $\mathrm{Ca}^{2+} / \mathrm{CaM}$ binds to these proteins and plays a regulatory role (see "Protein kinases (CDPKs)"). This adds complexity to the functionality of this group of proteins.

In the first section of this review, we will discuss a series of these CaM-LD containing proteins on a structural and functional level. This will include some enzymes (kinases, proteases, dehydrogenases and oxidases), and proteins with transport, hormonal, adaptor or structural functions. In the second section, we will discuss CaM-binding proteins that in addition to the CBS also contain a CLBS as defined by Jarrett and Madhavan [20]. There is no sequence homology of the CBSs or CLBSs in different proteins, except that they are rich in basic and acidic residues, respectively. These CLBSs lack EF-hand motifs, and are proposed to interact electrostatically with the CBSs when the latter are free of CaM. Therefore, they could provide a regulatory decoy system by binding to the CBS and preventing the action of $\mathrm{Ca}^{2+} / \mathrm{CaM}$ leading to autoinhibition. We will discuss the presence and function of CBS/CLBS motifs in some enzymes, transport proteins, and growth factor receptors. To highlight the communality of these regulatory domains in this diverse group of proteins, Fig. 1 depicts the organization of the major domains of some enzymes classified as containing either CaM-LD or CLBS/CBS domains discussed in this review. This arrangement allows either the direct and/or indirect (CaM-mediated) regulation of these enzymes by $\mathrm{Ca}^{2+}$ with great precision. Interestingly, the presence of an autoinhibitory domain that may have an independent identity, or to coincide with theirs CLBS or CBS appears to be common features of these enzymes to avoid unwanted activation in the absence of $\mathrm{Ca}^{2+}$ and/or the $\mathrm{Ca}^{2+}$ sensor CaM. 


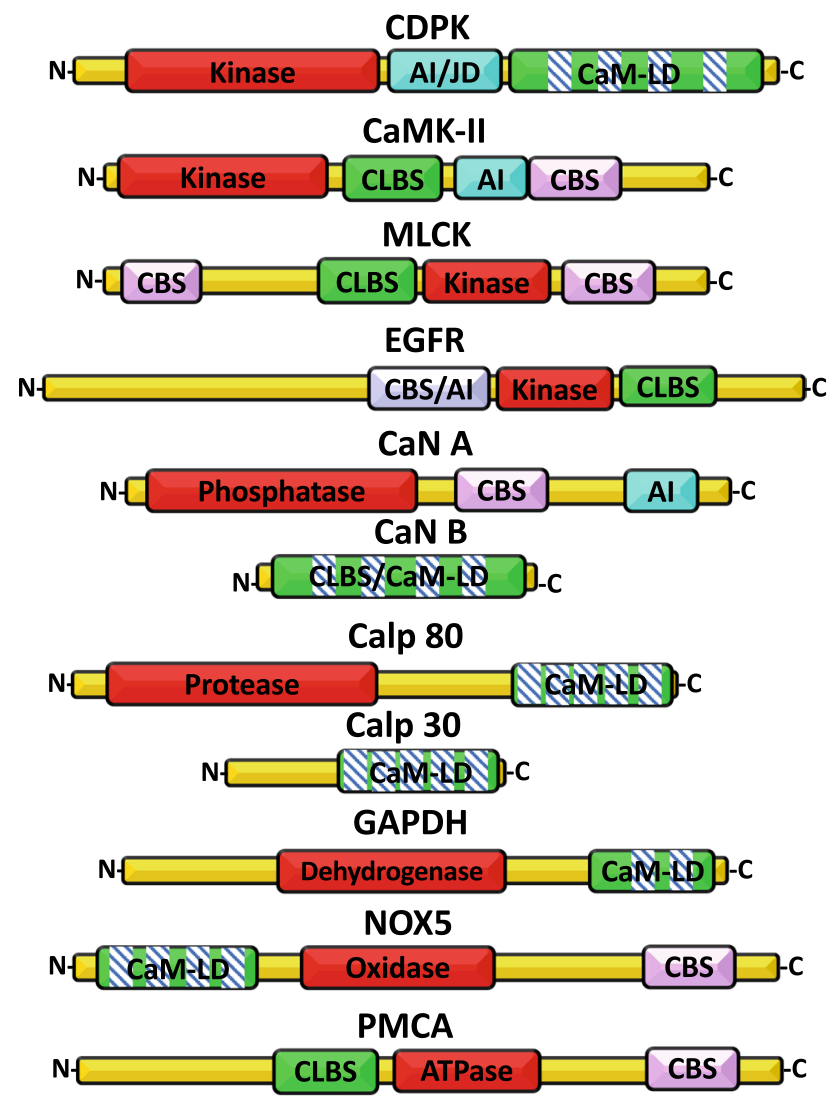

Fig. 1 Domain organization of some calmodulin-like domain (CaMLD)- and calmodulin-like binding site (CLBS)-containing proteins with enzymatic activity. The figure depicts the linear organization of the relevant domains of some enzymes with either a CaM-LD or CLBS. The domains shown are: catalytic site (red); CaM-LD or CLBS (green and EF-hands, boxes with bars, where applicable); autoinhibitory (AI)/junction (JD) domains (magenta); and calmodulin-binding site (CBS) (pink). CDPK CaM-like domain protein kinase, CaMK-II CaM-dependent protein kinase-II, $M L C K$ myosin light-chain kinase, EGFR epidermal growth factor receptor, $C a N A$ calcineurin A, CaN B calcineurin B, Calp 80 calpain $80 \mathrm{kDa}$ subunit, Calp 30 calpain $30 \mathrm{kDa}$ subunit, GAPDH glycerol-3-phosphate dehydrogenase, NOX5 NADPH oxidase 5, PMCA plasma membrane $\mathrm{Ca}^{2+}$-ATPase. The length of the proteins and different domains is not drawn to scale. The CBS and AI domains of the EGFR overlap [183]

\section{Proteins with EF-hand calmodulin-like domains (CaM-LDs)}

The occurrence of proteins containing a segment with an enzymatic (e.g., kinase or protease), or non-enzymatic domain (e.g., with transport or adaptor cytoskeletal function) and a segment resembling the helix-loop-helix EF-hand motifs found in $\mathrm{Ca}^{2+}$-binding proteins, such as $\mathrm{CaM}$, could be the result of the fusion of two genes with completely different functions and evolutionary origin. This has been proposed to be the case for calpains, a group of $\mathrm{Ca}^{2+}$-dependent cysteine endo-peptidases [21], as well as plant and protist calmodulin-like domain protein kinases [22, 23]. It is likely that this is also the origin of other proteins containing canonical EF-hand CaM-LDs, which are the focus of this section. Table 1 presents the amino acid sequence of the $\mathrm{Ca}^{2+}$-binding sites of selected proteins containing EF-hands.

\section{CaM-LD proteins with enzymatic activity}

Among the proteins with calmodulin-like domains and enzymatic activity most thoroughly studied are enzymes implicated in phosphorylation processes such as certain protein kinases in plants and protists denoted CDPKs, and proteases of the calpain family in vertebrates. In addition, enzymes involved in redox processes such as some dehydrogenases and oxidases also have calmodulin-like domains.

\section{Protein kinases (CDPKs)}

In many higher plants, algae and protists, a multi-gene family of $\mathrm{Ca}^{2+}$-dependent serine/threonine protein kinases denoted CDPKs presenting many isoforms was identified. These proteins contain as major structural features a variable N-terminal region, a catalytic domain similar to the one in calmodulin-dependent kinases (CaMKs), a regulatory junction domain connected to an adjoined $\mathrm{C}$-terminal regulatory domain similar to $\mathrm{CaM}$ named the CaM-like domain (CaM-LD) containing four EF-hand $\mathrm{Ca}^{2+}$ binding sites, although some isoforms with fewer sites have been identified (Figs. 1, 2a) [24]. The phylogeny of this extensive protein kinase family resulting from the fusion of an ancestral kinase gene and a CaM gene has been reviewed [23]. CDPKs have a high affinity for $\mathrm{Ca}^{2+}$ and do not require an exogenous $\mathrm{Ca}^{2+}$-binding protein for their activity, as they are directly activated by this cation due to their in-built CaMlike domain (reviewed in $[25,26]$ ). Through their enzymatic activity, these kinases transmit the $\mathrm{Ca}^{2+}$ signal generated by hormones, light and other effectors to diverse substrates, thereby regulating distinct physiological processes.

The junction between the kinase domain and the CaM-LD appears to exert an auto-inhibitory role acting as a pseudosubstrate-like structure blocking the catalytic site [27-29]. It was demonstrated that when the CaM-LD interacts with the junction this auto-inhibition is partially released. Nevertheless, for the total release of autoinhibition, not only $\mathrm{Ca}^{2+}$ binding to the high-affinity sites in the C-lobe but also $\mathrm{Ca}^{2+}$ occupancy of the lower affinity sites in the $\mathrm{N}$-lobe is required [30]. Binding of $\mathrm{Ca}^{2+}$ to the $\mathrm{C}$-lobe appears to increase the affinity of this cation for the $\mathrm{N}$-lobe, facilitating activation of the kinase in a cooperative manner (reviewed in [31]). Figure $2 \mathrm{~b}$ shows a putative model depicting the $\mathrm{Ca}^{2+}$-mediated activation of a CDPK. Nevertheless, structural analysis of the CDPK of Arabidopsis thaliana, AtCPK1, showed that this junction almost exclusively interacts with the high $\mathrm{Ca}^{2+}$ affinity C-lobe of the CaM-LD to release autoinhibition. This 
Table 1 Sequences of $\mathrm{Ca}^{2+}$-binding sites from selected EF-hand-containing proteins

\begin{tabular}{|c|c|c|c|}
\hline $\begin{array}{c}\text { Protein/Gene } \\
\text { (activity) }\end{array}$ & Species & $\mathrm{Ca}^{2+}-$ binding sites & $\begin{array}{l}\text { Reference } \\
\text { UniProt ID }\end{array}$ \\
\hline $\begin{array}{c}\text { SK5 }\left(^{a}\right) \\
\text { (Ser/Thr-protein } \\
\text { kinase) }\end{array}$ & $\begin{array}{c}\text { Soybean } \\
\text { (Glycine max) }\end{array}$ & $\begin{array}{l}\text { 348DTDNSGTITFDE }^{359} \\
\text { 384DIDKSGTIDYGE }^{395} \\
{ }^{420} \text { DKDGSGYITLDE }^{431} \\
{ }^{454} \text { DQDNDGQIDYGE }^{465}\end{array}$ & $\begin{array}{r}{[37]} \\
P 28583\end{array}$ \\
\hline $\begin{array}{c}\text { AtCDPK1 } \\
\text { (Ser/Thr-protein } \\
\text { kinase) }\end{array}$ & $\begin{array}{l}\text { Mouse-ear } \\
\text { cress } \\
\text { (Arabidopsis } \\
\text { thaliana) }\end{array}$ & $\begin{array}{l}\text { 464 DADKSGQITFEE }^{475} \\
\text { 500DVDNSGTIDYKE }^{511} \\
\text { 536DKDGSGYITPDE }^{547} \\
{ }^{570} \text { DQDNDGRIDYNE } 581\end{array}$ & $\begin{array}{c}{[37,218]} \\
Q 06850\end{array}$ \\
\hline $\begin{array}{c}\text { CrCDPK1 } \\
\text { (Ser/Thr-protein } \\
\text { kinase) }\end{array}$ & $\begin{array}{c}\text { Green algae } \\
\text { (Chlamydomo } \\
\text { nas reinhardtii) }\end{array}$ & $\begin{array}{l}\text { 485DKDKSGTISVEE }^{496} \\
\text { 522DVNGDGTIDYEE }^{533} \\
\text { 558DENGDGVITRQE }^{569} \\
{ }^{594} \text { DQDGNGTIEYGE }\end{array}$ & A8IPQ9 \\
\hline $\begin{array}{c}\text { PfCPK3 } \\
\text { (Ser/Thr-protein } \\
\text { kinase) }\end{array}$ & $\begin{array}{l}\text { Protozoan } \\
\text { (Plasmodium } \\
\text { falciparum) }\end{array}$ & 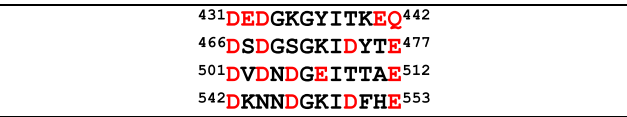 & $\begin{array}{c}\text { [219] } \\
\text { Q9NJU9 }\end{array}$ \\
\hline $\begin{array}{c}\text { TgCDPK1 } \\
\text { (Ser/Thr-protein } \\
\text { kinase) }\end{array}$ & $\begin{array}{l}\text { Protozoan } \\
\text { (Toxoplasma } \\
\text { gondii) }\end{array}$ & $\begin{array}{l}\text { 368 DKNGDGQLDRAE }^{379} \\
\text { 415DFDKNGYIEYSE }^{426} \\
{ }^{451} \text { DSDNSGKISSTE }^{462} \\
{ }^{485} \text { DKNNDGEVDFDE }^{496}\end{array}$ & $\begin{array}{c}\text { [220] } \\
\text { Q9BJF5 }\end{array}$ \\
\hline $\begin{array}{c}\text { TgCDPK4 }\left({ }^{b}\right) \\
\text { (Ser/Thr-protein } \\
\text { kinase) }\end{array}$ & & $\begin{array}{l}{ }^{948} \text { QQLDDLERLFRKIDIDNSGCIKMDRMVAVLVTFLDV } 983 \\
{ }^{1019} \mathrm{LNQQLIREAFERFDVDNSGHISLENLRYVLGDSYDS} \\
{ }^{1054} \\
{ }^{1057} \mathrm{VEEILRQCDRKQNGVIEFDEFMLALTGDESG}\end{array}$ & A0A125YGJ8 \\
\hline $\begin{array}{c}\alpha-\text { Actinin } \\
\text { (actin filament } \\
\text { binding protein) }\end{array}$ & $\begin{array}{c}\text { Algae } \\
\text { (Bigelowiella } \\
\text { natans) }\end{array}$ & $\begin{array}{l}\text { DDNSDGTLNRDE } \\
\text { GEGAETISKDL } \\
\text { LADGKSYITAEQ } \\
\text { GEEKGAFNYKQ }\end{array}$ & [221] \\
\hline $\begin{array}{c}\alpha-\text { Actinin-2 } \\
\text { (actin filament } \\
\text { binding protein) }\end{array}$ & $\begin{array}{l}\text { Amoeba } \\
\text { (Entamoeba } \\
\text { histolytica) }\end{array}$ & $\begin{array}{l}\text { DGNHDGILDKLE } \\
\text { TKGENGVSFDN } \\
\text { AAGKDSITETD } \\
\text { QKGDGYDYA }\end{array}$ & [103] \\
\hline $\begin{array}{l}\alpha-\text { Actinin-1 } \\
\text { (actin filament } \\
\text { binding protein) }\end{array}$ & $\begin{array}{l}\text { Human } \\
\text { (Homo } \\
\text { sapiens) }\end{array}$ & $\begin{array}{l}{ }^{759}{ }^{D R D H S G T L G P E E} \mathrm{E}^{770} \\
{ }^{800} \mathrm{DPNRLGVVTF} \mathrm{A}^{811}\end{array}$ & $\begin{array}{c}{[222]} \\
\text { P12814 }\end{array}$ \\
\hline $\begin{array}{l}\text { ATP/phosphate } \\
\text { exchanger } \\
\text { mitochondrial } \\
\text { (SCaMC-1) } \\
\text { (transport system) }\end{array}$ & $\begin{array}{l}\text { Human } \\
\text { (Homo } \\
\text { sapiens) }\end{array}$ & 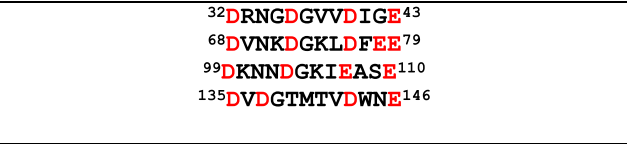 & $\begin{array}{c}\text { [223] } \\
\text { Q6NUK1 }\end{array}$ \\
\hline $\begin{array}{l}\text { Calcineurin-B } \\
\text { (regulatory subunit of } \\
\mathrm{Ca}^{2+} \text {-dependent } \\
\text { phosphatase) }\end{array}$ & $\begin{array}{l}\text { Baker's yeast } \\
\text { (Saccharomyc } \\
\text { es cerevisiae) }\end{array}$ & $\begin{array}{l}{ }^{34} \text { DRDSSGSIDKNE } \\
\text { 66 DADNSGDVDFQE } \\
{ }^{77} \\
{ }^{103}{ }^{2} \text { IDKDGFISNGE } \\
{ }^{114} \text { DSDGDGRISFEE }^{155}\end{array}$ & $\begin{array}{c}{[224]} \\
P 25296\end{array}$ \\
\hline $\begin{array}{l}\text { Calcineurin-B } \\
\text { type } 1 \\
\text { (regulatory subunit of } \\
\mathrm{Ca}^{2+} \text {-dependent } \\
\text { phosphatase) }\end{array}$ & $\begin{array}{l}\text { Human } \\
\text { (Homo } \\
\text { sapiens) }\end{array}$ & $\begin{array}{l}\text { 31DLDNSGSLSVEE }{ }^{42} \\
\text { 63DTDGNGEVDFKE }{ }^{74} \\
{ }^{100} \text { DMDKDGYISNGE } 111 \\
{ }^{141} \text { DKDGDGRISFEE }^{152}\end{array}$ & $\begin{array}{c}{[225]} \\
P 63098\end{array}$ \\
\hline Calpain-A & Fruit fly & ${ }^{712}$ DADKSGKLGFEE ${ }^{723}$ & [226] \\
\hline $\begin{array}{c}\text { m-Calpain } \\
\left(\mathrm{Ca}^{2+} \text {-dependent }\right. \\
\text { Cys-protease }) \\
\end{array}$ & $\begin{array}{c}\text { (Drosophila } \\
\text { melanogaster) }\end{array}$ & ${ }^{742}$ DVENTGRVSGFQ ${ }^{753}$ & Q11002 \\
\hline $\begin{array}{l}\text { Calpain-1/ } \\
\mu \text {-Calpain }\left({ }^{b}\right) \\
\text { catalytic subunit } \\
\left(\mathrm{Ca}^{2+} \text {-dependent }\right. \\
\text { Cys-protease })\end{array}$ & $\begin{array}{l}\text { Human } \\
\text { (Homo } \\
\text { sapiens) }\end{array}$ & $\begin{array}{c}9^{99} \text { VDGATRTD } 106 \\
{ }^{302} \text { EWTGAWSDSSSEWNNVDPYERDQLRVKMEDGE } \\
\end{array}$ & $\begin{array}{c}{[227]} \\
P 07384\end{array}$ \\
\hline $\begin{array}{l}\text { Calpain-2/ } \\
\text { m-Calpain } \\
\text { catalytic subunit } \\
\left(\mathrm{Ca}^{2+} \text {-dependent }\right. \\
\text { Cys-protease })\end{array}$ & $\begin{array}{l}\text { Human } \\
\text { (Homo } \\
\text { sapiens) }\end{array}$ & $\begin{array}{l}{ }^{585} \text { DSDGSGKLGLKE }^{596} \\
{ }^{615} \text { DVDSGTMNSYE }^{626}\end{array}$ & $\begin{array}{c}{[228]} \\
\text { P17655 (c) }\end{array}$ \\
\hline $\begin{array}{l}\text { Calpain-3 } \\
\left(\mathrm{Ca}^{2+} \text {-dependent }\right. \\
\text { Cys-protease })\end{array}$ & $\begin{array}{l}\text { Human } \\
\text { (Homo } \\
\text { sapiens) }\end{array}$ & 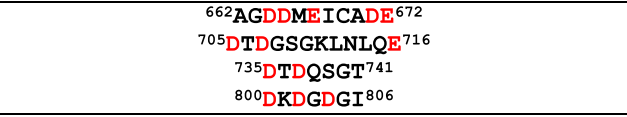 & $\begin{array}{c}\text { [229] } \\
\text { P20807 }\end{array}$ \\
\hline $\begin{array}{l}\text { Cartilage oligomeric } \\
\text { matrix protein }\left({ }^{c}\right) \\
\text { Thrombospondin-5 } \\
\text { (extracellular protein) }\end{array}$ & $\begin{array}{l}\text { Human } \\
\text { (Homo } \\
\text { sapiens) }\end{array}$ & $\begin{array}{l}{ }^{127} \text { DVNECNAHPCFPRVRCINTSPGFRCEACPPGYSGPTHQG } \\
\text { VGLAFAKANKQVCT } \\
{ }^{179} \\
{ }^{180} \text { DINECETGQHNCVPNSVCINTRGSFQCGPCQPGFVGDQA } \\
\text { SGCQ }^{222}\end{array}$ & $\begin{array}{c}{[230]} \\
\text { P49747 }\end{array}$ \\
\hline $\begin{array}{l}\text { Glycerol-3-phosphate } \\
\text { dehydrogenase } \\
\text { (mitocondrial) }\end{array}$ & $\begin{array}{l}\text { Human } \\
\text { (Homo } \\
\text { sapiens) }\end{array}$ & ${ }^{672}$ DLNKNGQVELNE ${ }^{683}$ & $\begin{array}{c}{[231]} \\
P 43304\end{array}$ \\
\hline
\end{tabular}


Table 1 (continued)

Acidic amino acid residues are marked (red)

$C D P K$ CaM-like domain protein kinase, $C P K \mathrm{Ca}^{2+}$-dependent protein kinase

${ }^{a}$ Undefined isoenzyme

${ }^{\mathrm{b}}$ Potential $\mathrm{Ca}^{2+}$-binding sites are underlined

${ }^{\mathrm{c}}$ Binds 11-14 calcium ions per subunit, the indicated sequences correspond to $\mathrm{Ca}^{2+}$-binding sites in EGF-like domains 2 and 3

suggests activation of the kinase even at low basal $\mathrm{Ca}^{2+}$ concentrations [32]. Although this mechanism does not appear to be sufficient to attain full activation of the enzyme, mutations at the CaM-LD and the linker connecting this domain with the kinase domain block its enzymatic activity, and the activity of a mutant lacking the CaM-LD can be reconstituted upon addition of either this isolated domain or $\mathrm{CaM}$ [33-35]. CDPKs and CDPK-related kinases from plants and protists are able to undergo autophosphorylation, and a common locus of the autophosphorylation sites in the $\mathrm{N}$-terminal variable domain has been identified [36].

The first $\mathrm{Ca}^{2+}$-dependent kinase (CDPK) was discovered in 1991 in soybean (Glycine max), later denoted CDPK $\alpha$ [37], followed by the identification of isoforms CDPK $\beta$ and CDPK $\gamma$ with different kinetic properties and $\mathrm{Ca}^{2+}$ affinities indicating distinct functional roles [38]. Further, CDPKs were later on found in many other higher plants, green algae and protists. Table 1 shows that the EF-hands in these proteins are highly conserved, especially the $\mathrm{Ca}^{2+}$ coordinating acidic residues $\mathrm{D}$ and $\mathrm{E}$ at position 1 and 12 (highlighted in red), and Table 2 shows similarities in the sequence of the autoinhibitory/junction domain. Interestingly, a phenylalanine (underlined in bold) in higher plant CDPKs appears to have an important functional role [32], similarly to a highly conserved segment in protozoan CDPKs (underlined in bold). Figure 2a depicts the crystallographic structure of $A$. thaliana CDPK1 highlighting the four EF-hands $\mathrm{Ca}^{2+}$ binding sites in the C-terminal CaM-LD.

Some CDPKs bind and are regulated by $\mathrm{CaM}$. It was shown that $A$. thaliana CPK28 binds $\mathrm{Ca}^{2+} / \mathrm{CaM}$ at its junctional domain with high affinity inhibiting its activity. However, when CPK28 is autophosphorylated it primes the enzyme for $\mathrm{Ca}^{2+}$ binding at low concentration, and this reduces the inhibitory effect of $\mathrm{Ca}^{2+} / \mathrm{CaM}$ [39]. Of interest, the activation loop of some CDPKs contains acidic amino acid residues, which prevent Ser/Thr phosphorylation [40]. Therefore, it could be speculated that this acidic site may work as well as a CLBS (see "Calmodulin-binding proteins with non-EF-hand CaM-like binding sites (CLBSs)") possibly interacting with the CBS of these enzymes. The junction domain of soybean CDPK $\alpha$ induces a significant structural change in the C-terminal domain of the isolated CaM-LD in the presence of $\mathrm{Ca}^{2+}$ without forming a stable complex as determined by NMR spectroscopy [41]. Moreover, the Nand C-lobes of the CaM-LD adopt a side-by-side position, unlike $\mathrm{CaM}$, and similar to calcineurin B [42]. Using FRET, it was demonstrated that the CaM-LD is partially unfolded in the absence of $\mathrm{Ca}^{2+}$ and folds upon $\mathrm{Ca}^{2+}$ binding [43] (see Fig. 2b).

Autophosphorylation is a $\mathrm{Ca}^{2+}$-dependent process and considered to be a requirement for plant CDPK activation, as demonstrated in groundnut (Arachis hypogaea) CDPK [44]. This CDPK, an example of a group of atypical structurally similar CDPKs, containing a bipartite NLS at their autoinhibitory junction domain and non-canonical EF-hands, binds $\mathrm{Ca}^{2+}$ with very low affinity. The presence of a bipartite NLS is shared by many other CDPKs including ginger (Zingiber oficinale) ZoCDPK1 and Arabidopsis AtCPK30 among others [45]. As expected, this kinase is localized in the nucleus and its junction domain in its activated form has been shown to interact with importins, which are localized at the nuclear pores participating in the translocation process [46]. As autophosphorylation at a tyrosine residue has been reported recently, it was suggested that CDPKs could work as dual-specific protein kinases [47]. In some instances, however, autophosphorylation has been shown to be $\mathrm{Ca}^{2+}$-independent and to induce inhibition of the enzyme [48]. The functionality of these kinases appears to be diverse as they act on many different targets. Table 3 collects some functional roles of selected examples of these kinases in different plants and other organisms. Relevant in this context is the fundamental role of CDPKs in defense response to pathogens and herbivores attack (reviewed in [49]).

CaM-like domain protein kinases similar to the abovedescribed plant enzymes have been identified in green algae $[50,51]$ and protists (see Table 3). Protist CDPKs exhibit a more elaborated mechanism of activation. Binding of $\mathrm{Ca}^{2+}$ to the CaM-LD releases the auto-inhibition, as in the case of plant CDPKs, but the junction/CaM-LD complex further interacts with a segment of the kinase domain and a 'latch' with the variable N-terminal domain (not shown in Fig. 2b). This contributes to the allosteric activation of the enzyme. Nevertheless, it is likely that plant CDPKs may have a similar activation mechanism (reviewed in [52]).

In the protozoan Plasmodium falciparum, the causing agent of malaria, up to seven CDPKs are expressed, what aroused interest as potential therapeutic targets due to their important role in transducing essential $\mathrm{Ca}^{2+}$-mediated signaling as well as the fact that mammals do not express similar proteins (reviewed in [53]). The structural and functional 

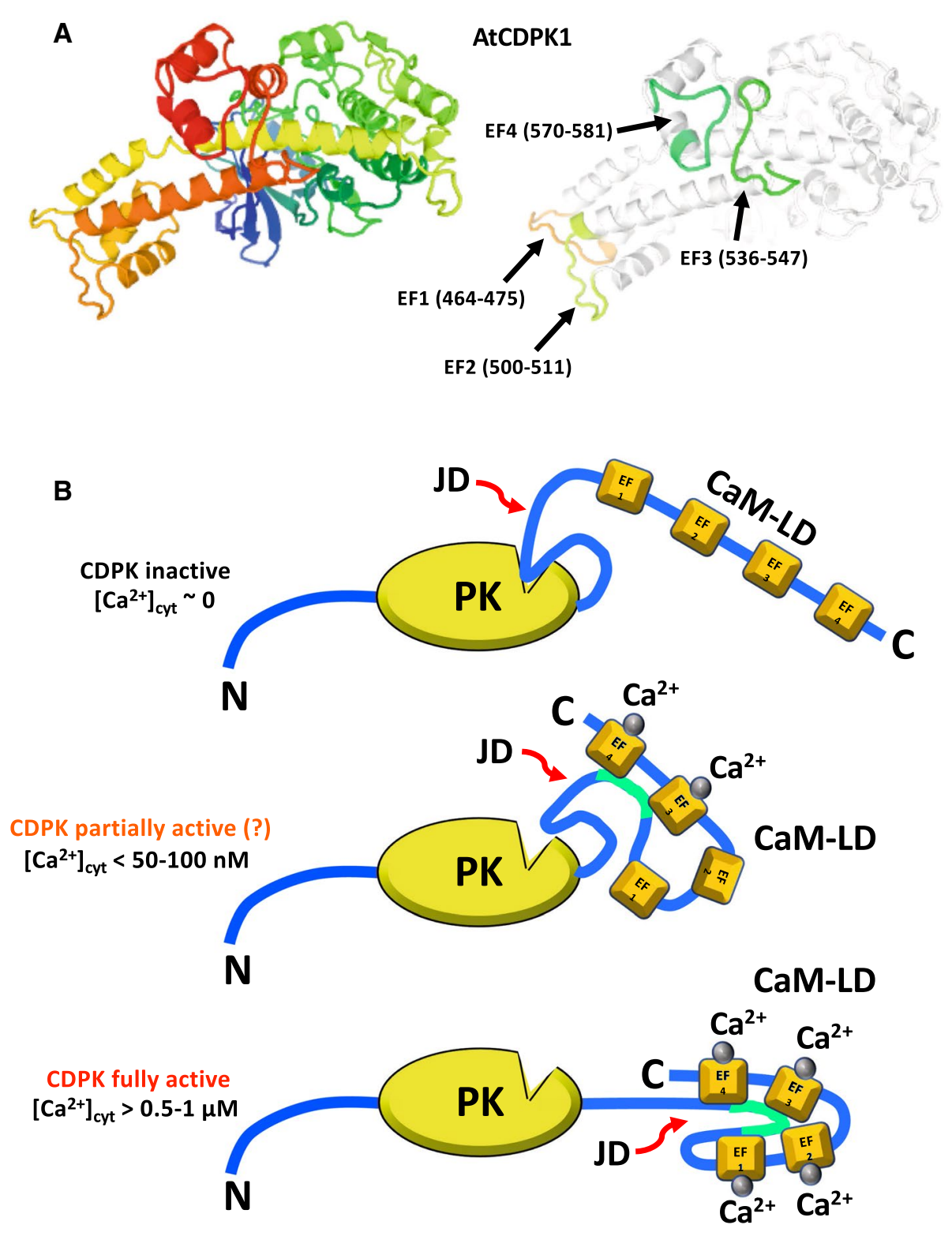

Fig. 2 Structure and $\mathrm{Ca}^{2+}$-mediated activation of a calmodulin-like domain protein kinase. a The figure depicts the X-ray crystallographic structure of $\mathrm{Ca}^{2+}$-dependent protein kinase 1 (AtCDPK1) from Arabidopsis thaliana at $2 \AA$ resolution (Q06850 CDPK1_ ARATH based on template $4 \mathrm{~m} 97 \mathrm{~A}$, residue range 142-588) taken from UniProt SWISS-MODEL database. The crystallographic structure in the left panel is shown using a rainbow color code going from the $\mathrm{N}$-terminal (blue) to the $\mathrm{C}$-terminal (red). The $\mathrm{Ca}^{2+}$-binding sites in the four EF-hands are highlighted in the right panel in different colors indicating the amino acid residues involved. b The figure depicts a model for the $\mathrm{Ca}^{2+}$-dependent activation of a CaM-like domain protein kinase (CDPK). In the absence of $\mathrm{Ca}^{2+}$, a non-physiological condition, when the four EF-hands of the CDPK are free of $\mathrm{Ca}^{2+}$ (apo-CDPK), a sector of the junction domain (JD) blocks the catalytic site of the protein kinase (PK) rendering the enzyme inactive

features of the $\mathrm{Ca}^{2+}$-binding sites at the $\mathrm{N}$ - and C-lobes of the CaM-like domain of CDPK3 in this parasite has been studied in detail using recombinant proteins of each lobe (top panel). In basal conditions, when the cytosolic $\mathrm{Ca}^{2+}$ concentration is very low $(<50-100 \mathrm{nM})$ the high-affinity $\mathrm{Ca}^{2+}$-binding sites located in the distal EF-hands 3 and 4 are occupied and both of them interact with the JD (marked in green), the catalytic site is partially released and the enzyme becomes partially active (central panel). The interrogation mark indicates a discrepancy in the literature as to whether binding of $\mathrm{Ca}^{2+}$ to EF-hands 3 and 4 is sufficient to at least partially release the auto-inhibition (see references [27-31]). When the cytosolic $\mathrm{Ca}^{2+}$ concentration increases at saturating concentrations $(>0.5-1 \mu \mathrm{M})$, the two low-affinity $\mathrm{Ca}^{2+}$-binding sites located in EF-hands 1 and 2 are also occupied by $\mathrm{Ca}^{2+}$, and all EF-hands interact with the JD (marked in green) which is totally released from the catalytic site rendering the enzyme fully active (bottom panel). $\mathrm{Ca}^{2+}$ ions are represented by gray spheres. CaM- $L D$ calmodulin-like domain. Partially based on references $[31,36]$

[54]. It was found that the C-lobe was constitutively occupied by $\mathrm{Ca}^{2+}$, as it could not be prepared in its $\mathrm{Ca}^{2+}$-free form, and was found in a dimeric form. This is in contrast 
Table 2 Sequence of selected CDPK autoinhibitory/junction domains

\begin{tabular}{llcc}
\hline CDPK & Species & Autoinhibitory/junction domain & Identity $(\%)$ \\
UniProt ID
\end{tabular}

In higher plant CDPKs the residues in bold indicate changes with respect to soybean CDPK, and a conserved functionally important phenylalanine residue is underlined in bold [32]. In P. falciparum and $T$. gondii the underlined segment is highly conserved and may represent a functionally important segment

${ }^{\text {a }}$ Small segment of the autoinhibitory/junction domain [32]

${ }^{\mathrm{b}}$ Two helical segments of the autoinhibitory/junction domain [232]

to the N-lobe, which did not form dimers and changed its structure upon binding of a single $\mathrm{Ca}^{2+}$ ion. This may indicate if confirmed with the full-length protein, that the $\mathrm{C}$-lobe is $\mathrm{Ca}^{2+}$ saturated even at basal intracellular concentration and that activation occurs due to structural changes induced by $\mathrm{Ca}^{2+}$ binding to the $\mathrm{N}$-lobe as suggested by the authors of this report. Using the CDPK4 isoform of this parasite, a model of $\mathrm{Ca}^{2+}$-mediated activation of this kinase was proposed, in which the junctional domain occupies its catalytic domain, acting as a pseudo-substrate when the CaM-LD is in its $\mathrm{Ca}^{2+}$-free form, as in other CDPKs [55] (see Fig. 2b). Upon $\mathrm{Ca}^{2+}$ binding, the junctional domain is detached exposing this site and allowing its auto-phosphorylation at Thr234, which activates the enzyme.

The causative agent of toxoplasmosis, the pathogenic intracellular protozoan Toxoplasma gondii, expresses $\mathrm{Ca}^{2+}$-dependent/phospholipid-independent CDPKs. These kinases could be valid targets to prevent invasion of the parasite transmitted by cats gravely affecting the fetus in pregnant women. In this context, imidazopyridine, an inhibitor of PKG used against this and other coccidial parasites, has been shown to specifically inhibit as well CDPK1 in $T$. gondii with very high (sub-nanomolar) affinity [56]. The socalled "bumped" kinase inhibitors are those that compete for ATP. Thereby they inhibit protozoan kinases but not mammalian kinases because the latter usually contain a bulky gatekeeper residue in the catalytic site that prevents entry of the inhibitor (reviewed in [57]). These CDPK inhibitors have been found useful for the treatment of protozoal diseases. However, resistance to this class of inhibitors has been found when MAPK1, but not CDPK1, in T. gondii is mutated [58].
Based on these and other results it has been suggested to develop CDPK-based vaccines against $T$. gondii (reviewed in [59]). Parasitic protozoans of the genus Eimeria, also expressing CDPKs, are the agents causing coccidiosis [60].

\section{The calpain protein family}

Calpains form a family of $\mathrm{Ca}^{2+}$-dependent cysteine neutral proteases with at least fourteen isoforms in human coded from different genes. These proteases play a variety of important roles, as they perform restricted controlled proteolysis on target substrates modulating in this fashion their functionality (reviewed in [61-63]). They also participate in the onset of different pathologies including cancer (reviewed in [64]). The major functional classification system of calpains is based on the affinity of these enzymes for $\mathrm{Ca}^{2+}$. This includes $\mu$-calpain (calpain-1) with high affinity for $\mathrm{Ca}^{2+}(3-50 \mu \mathrm{M})$, and $\mathrm{m}$-calpain (calpain-2) with a very low affinity for this cation $(0.2-1 \mathrm{mM})$. A third type is calpain-3, which is also dependent on $\mathrm{Na}^{+}$and has some peculiar properties, such as the propensity to become reactivated by intermolecular complementation of the fragments after auto-proteolysis. $\mathrm{Ca}^{2+}$ binding induces the autoproteolytic activation of calpains. Interestingly, calpain-5 was shown to be able to undergo $\mathrm{Ca}^{2+}$-dependent processing in a human neuroblastoma cell line even though it does not contain a CaM-LD [65].

Calpains are heterodimers constituted of $80 \mathrm{kDa}$ and $30 \mathrm{kDa}$ subunits. Five EF-hands domains are found in both subunits at their C-terminal region, of which only three or four in the large subunit and some in the smaller subunit 
Table 3 Biological functions and some properties of selected CDPKs

\begin{tabular}{|c|c|c|c|}
\hline CDPK isoform & Species & Biological functions and properties & References \\
\hline $\mathrm{MsCPK} 3$ & Alfalfa (Medicago sativa) & $\begin{array}{l}\text { Sensitive to CaM antagonists. Responsive to } \\
\text { auxin, role in embryogenesis and thermal stress } \\
\text { response. Phosphorylates a CDK inhibitor } \\
\text { enhancing its inhibitory activity and blocking the } \\
\text { cell cycle }\end{array}$ & [233-235] \\
\hline VfCDPK $^{\mathrm{a}}$ & Bean (Vicia faba) & $\begin{array}{l}\text { Phosphorylates and inhibits the } \mathrm{K}^{+} \text {rectifying } \\
\text { channel KAT1 in guard cells; leads to closure of } \\
\text { stomas } \\
\text { This CDPK works upstream of a } 48 \mathrm{kDa} \\
\mathrm{Ca}^{2+} \text {-independent kinase responsive to abscisic } \\
\text { acid involved in stomatal closure }\end{array}$ & $\begin{array}{l}{[236]} \\
{[237]}\end{array}$ \\
\hline $\begin{array}{l}\text { DcCPK1 } \\
\text { CRK }\end{array}$ & Carrot (Daucus carota) & $\begin{array}{l}\text { Sensitive to CaM antagonists. Activated by acidic } \\
\text { phospholipids } \\
\text { CDPK-related kinase. Degenerated EF-hands. } \\
\text { N-terminal extension with myristoylation consen- } \\
\text { sus sequence }\end{array}$ & $\begin{array}{l}{[238,239]} \\
{[240]}\end{array}$ \\
\hline $\mathrm{CaCPK} 1, \mathrm{CaCPK} 2$ & Chickpea (Cicer arietinum) & Sensitive to CaM antagonists & {$[241]$} \\
\hline $\begin{array}{l}\mathrm{ZmCDPK}^{\mathrm{a}} \\
\text { ZmCPK11 (ZmCPKp54) } \\
\text { CRPK1, CRPK2 }\end{array}$ & Corn (Zea mays) & $\begin{array}{l}\text { Phosphorylates the } \mathrm{C} \text {-terminal region of plasma } \\
\text { membrane } \mathrm{H}^{+} \text {-ATPase in vitro, no effect on } \\
\text { ATPase activity. Phosphorylates ADF/cofilin; } \\
\text { leads to actin cytoskeleton disassembly } \\
\text { Involved in drought response } \\
\text { Involved in wound response. Activated by acidic } \\
\text { phospholipids; present in seeds, plant seedling } \\
\text { and other organs } \\
\text { Root-specific isoforms }\end{array}$ & $\begin{array}{l}{[242,243]} \\
{[40]} \\
{[244,245]} \\
{[246]}\end{array}$ \\
\hline CsCDPK5 & Cucumber (Cucumis sativus) & $\begin{array}{l}\text { Upregulated by phytohormones (benzyladenine, } \\
\text { abscisic acid, gibberellic acid and indole acetic } \\
\text { acid) in a light-dependent and independent man- } \\
\text { ner } \\
\text { N-Myristoylation motif absent }\end{array}$ & [247] \\
\hline ZoCDPK1 & Ginger (Zingiber officinale) & $\begin{array}{l}\text { Involved in response to multiple stresses including } \\
\text { high salt and drought. Contains a bipartite NLS at } \\
\text { its junction domain }\end{array}$ & [45] \\
\hline $\mathrm{AhCPK} 2$ & Groundnut (Arachis hypogaea) & $\begin{array}{l}\text { Translocates to the nucleus in response to hyper- } \\
\text { tonic stress. Non-functional second EF-hand. } \\
\text { Very low } \mathrm{Ca}^{2+} \text { affinity }\left(K_{d}=392 \mu \mathrm{M}\right) \text {. Bipartite } \\
\text { NLS at the junction domain }\end{array}$ & [46] \\
\hline IiCPK2 & Indigowood (Isatis indigotica) & Involved in stress response to cold and high salinity & [248] \\
\hline $\mathrm{LjCDPK}^{\mathrm{a}}$ & Birds' foot trefoil (Lotus japonicas) & $\begin{array}{l}\text { Phosphorylates aquaporin LIMP-2 (nodulin-26 } \\
\text { orthologue) in } \mathrm{N}_{2} \text {-fixing root nodules }\end{array}$ & {$[249]$} \\
\hline $\begin{array}{l}\text { AtCDPK } \\
\text { AK1-6H } \\
\text { CPK9 }\end{array}$ & Mouse-ear cress (Arabidopsis thaliana) & $\begin{array}{l}\text { Express many isoforms. The } 72-\mathrm{kDa} \text { isoform } \\
\text { has a N-terminal extension and is synergistically } \\
\text { activated by } \mathrm{Ca}^{2+} \text { and phospholipids } \\
\text { Involved in drought response } \\
\text { Phosphorylates and activates NADPH oxidase } \\
\text { when ectopically expressed in tomato protoplasts } \\
\text { enhancing ROS production. Phospho-NADPH } \\
\text { oxidase dephosphorylated by protein phosphatase } \\
\text { 2A. Involved in parasite defense mechanisms } \\
\text { Transferred DNA (T-DNA) of the mutagenic } \\
\text { tumor-inducing bacteria Agrobacterium tume- } \\
\text { faciens is inserted in the gene inactivating this } \\
\text { isoform }\end{array}$ & $\begin{array}{l}{[218,250,251]} \\
{[40]} \\
{[252]} \\
{[253]}\end{array}$ \\
\hline $\begin{array}{l}\text { PiCDPK1 } \\
\text { PiCDPK2 }\end{array}$ & Petunia (Petunia inflata) & Controls the growth and polarity of the pollen tube & [254] \\
\hline $\operatorname{PrCDPK}^{\mathrm{a}}$ & Poppy (Papaver rhoeas) & $\begin{array}{l}\text { Phosphorylates a pollen } 26-\mathrm{kDa} \text { protein to prevent } \\
\text { self-pollination }\end{array}$ & [255] \\
\hline StCPK1 & Potato (Solanum tuberosum) & CDPK-related kinase with canonical EF-hands & [256] \\
\hline
\end{tabular}


Table 3 (continued)

\begin{tabular}{|c|c|c|c|}
\hline CDPK isoform & Species & Biological functions and properties & References \\
\hline $\mathrm{CmCPK} 1$ & Pumpkin (Cucurbita maxima) & $\begin{array}{l}\mathrm{N} \text {-terminal proteolytically cleavaged form enters } \\
\text { the phloem and phosphorylates sap proteins }\end{array}$ & {$[257]$} \\
\hline OsCDPK $^{\mathrm{a}}$ & Rice (Oryza sativa) & Involved in drought response & {$[40]$} \\
\hline $\mathrm{SPK}^{\mathrm{a}}$ & & $\begin{array}{l}\text { Phosphorylates sucrose synthase; regulates starch } \\
\text { storage in grain }\end{array}$ & {$[258,259]$} \\
\hline $\mathrm{SbCDPK}^{\mathrm{a}}$ & Sorghum (Sorghum bicolor) & Involved in drought response & [40] \\
\hline $\begin{array}{l}\mathrm{CDPK} \alpha \\
\mathrm{CDPK} \beta \\
\mathrm{CDPK} \gamma \\
\mathrm{GmCDPK}^{\mathrm{a}}\end{array}$ & Soybean (Glycine max) & $\begin{array}{l}\text { CDPK } \alpha \text { higher } \mathrm{Ca}^{2+} \text { affinity }\left(K_{0.5}=0.06 \mu \mathrm{M}\right) \text { than } \\
\text { CDPK } \beta\left(K_{0.5}=0.4 \mu \mathrm{M}\right) \text { and CDPK } \gamma\left(K_{0.5}=1 \mu \mathrm{M}\right) \\
\text { Phosphorylates the symbiosome membrane protein } \\
\text { nodulin-26 in } \mathrm{N}_{2} \text {-fixing root nodules regulating } \\
\text { its voltage-dependent channel activity }\end{array}$ & $\begin{array}{l}{[37,38]} \\
{[260]}\end{array}$ \\
\hline SoCDPK $^{\mathrm{a}}$ & Spinach (Spinacia oleracea) & $\begin{array}{l}\text { Phosphorylates leaf nitrate reductase; decreases } \\
\text { nitrate assimilation via 14-3-3 protein binding } \\
\text { Phosphorylates and inhibits leaf sucrose-phosphate } \\
\text { synthase arresting sucrose biosynthesis }\end{array}$ & $\begin{array}{l}{[261]} \\
{[262]}\end{array}$ \\
\hline FaCDPK1 & Strawberry (Fragaria ananassa) & $\begin{array}{l}\text { Fruit development, transcript increases at low } \\
\text { temperature. Three EF-hands only }\end{array}$ & [263] \\
\hline $\mathrm{BvCDPK}^{\mathrm{a}}$ & Sugar beet (Beta vulgaris) & $\begin{array}{l}\text { Phosphorylates and inhibits plasma membrane } \\
\mathrm{H}^{+} \text {-ATPase in root cells }\end{array}$ & {$[264]$} \\
\hline $\mathrm{NtCDPK} 1$ & Tobacco (Nicotiana tabacum) & Responsive to phytohormones and tissue wounding & {$[265]$} \\
\hline $\begin{array}{l}\text { LeCPK1 } \\
\text { LeCPK2 } \\
\text { LeCRK1 }\end{array}$ & Tomato (Solanum lycopersicum) & $\begin{array}{l}\text { LeCPK1 phosphorylates the C-terminus of plasma } \\
\text { membrane } \mathrm{H}^{+} \text {-ATPase. LeCPK2 responsive } \\
\text { to phytohormones and mechanical injuries. } \\
\text { Myristoylation of LeCPK1 N-terminus required } \\
\text { for plasma membrane localization; } \mathrm{Ca}^{2+} \text {-binding } \\
\text { sites of low }\left(K_{d}=55 \mu \mathrm{M}\right) \text { and high }\left(K_{d}=0.6 \mu \mathrm{M}\right) \\
\text { affinity } \\
\text { LeCPK2 very high affinity for } \mathrm{Ca}^{2+} \\
\left(K_{0.5}=45-49 \mathrm{nM}\right) \\
\text { Degenerated CaM-LD unable to bind } \mathrm{Ca}^{2+} \text {. Con- } \\
\text { tains a CaM-binding site as assayed in vitro } \\
\text { Involved in ripening }\end{array}$ & $\begin{array}{l}{[266-268]} \\
{[269]}\end{array}$ \\
\hline TaCDPK1 & Wheat (Triticum aestivum) & Expression upregulated by sucrose & {$[270]$} \\
\hline $\mathrm{PtCDPK} / \mathrm{WbCDPK}$ & Winged bean (Psophocarpus tetragonolobus) & $\begin{array}{l}\text { Sensitive to CaM antagonists } \\
\text { The 70-kDa isoform is unable to undergo autophos- } \\
\text { phorylation } \\
\text { Dephosphorylated by serine-phosphatase WbPP }\end{array}$ & $\begin{array}{l}{[48,271]} \\
{[272]}\end{array}$ \\
\hline $\mathrm{EtCDPK}^{\mathrm{a}}$ & Protozoan (Eimeria tenella) & $\begin{array}{l}\text { Involved in the invasion of host cells by the sporo- } \\
\text { zoite } \\
\text { Located in the apical filament-like structure of the } \\
\text { sporozoite }\end{array}$ & {$[60]$} \\
\hline $\begin{array}{l}\text { PfCDPK1 } \\
\text { PfCDPK3 } \\
\text { PfCDPK4 }\end{array}$ & Protozoan (Plasmodium falciparum) & $\begin{array}{l}\text { Phosphorylates the protease PfSERA5. Implicated } \\
\text { in invasion and the egress of merozoites from the } \\
\text { erythrocyte } \\
\text { Implicated in gametogenesis of the parasite } \\
\text { Sensitive to CaM antagonists }\end{array}$ & $\begin{array}{l}{[273,274]} \\
{[219]} \\
{[275]}\end{array}$ \\
\hline $\mathrm{PbCDPK} 4$ & Protozoan (Plasmodium berghei) & $\begin{array}{l}\text { Translates the } \mathrm{Ca}^{2+} \text { signal generated by xanthurenic } \\
\text { acid in gametocytes inducing its differentiation to } \\
\text { mature gametes }\end{array}$ & [276] \\
\hline $\begin{array}{l}\text { TgCDPK1 } \\
\text { TgCDPK } 4\end{array}$ & Protozoan (Toxoplasma gondii) & $\begin{array}{l}\text { Involved in motility, host cell attachment and the } \\
\text { invasive capacity of the parasite. Expressed in } \\
\text { tachyzoites } \\
\text { Phosphorylates aldolase- } 1 \text { forming part of the } \\
\text { glideosome apparatus which is required for para- } \\
\text { site invasiveness }\end{array}$ & $\begin{array}{l}{[107]} \\
{[277]}\end{array}$ \\
\hline
\end{tabular}

$A D F$ actin-depolymerizing factor, $C a M$ calmodulin, $C D K$ cyclin-dependent kinase, $C D P K$ CaM-like domain protein kinase, $C P K$ $\mathrm{Ca}^{2+}$-dependent protein kinase, $N L S$ nuclear localization sequence, $R O S$ reactive oxygen species

${ }^{\mathrm{a}}$ Isoform not described 

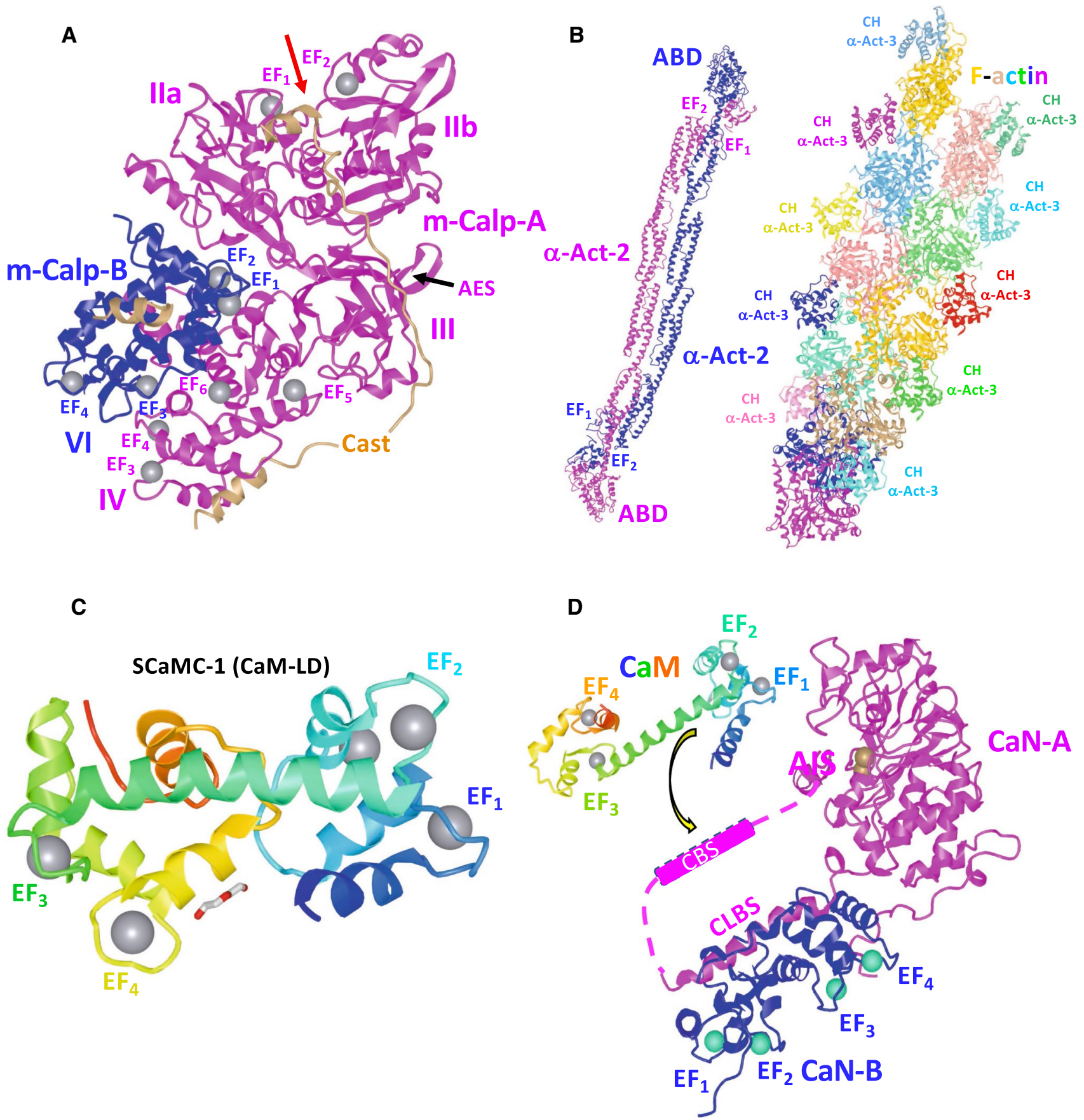

are able to bind $\mathrm{Ca}^{2+}$ (Fig. 1). The catalytic domain of calpain is divided in two sub-domains, IIa and IIb, separated by cleft allowing access of the substrate to the catalytic center (Fig. 3a) [66, 67]. The activity of a recombinant $\mu$-calpain lacking the CaM-LD (domain IV) was shown to be independent of $\mathrm{Ca}^{2+}$, and a chimeric $\mu / \mathrm{m}$-calpain in which the native CaM-LD (domain IV) [68] of $\mu$-calpain was replaced by the one of $\mathrm{m}$-calpain presents the highest affinity for $\mathrm{Ca}^{2+}$ [69]. The physiological concentration of cytosolic $\mathrm{Ca}^{2+}$ appears to be too low for full activation of either $\mu$-calpain or m-calpain in living cells. Several mechanisms have been suggested to solve this dilemma, from increasing $\mathrm{Ca}^{2+}$ availability by co-localization with $\mathrm{Ca}^{2+}$-channels, and/or to increase the effective $\mathrm{Ca}^{2+}$ affinity in vivo by binding to membranes and subsequent activation by acidic phospholipids or regulation by a phosphorylation/dephosphorylation mechanism, and the existence of a hypothetical $\mathrm{Ca}^{2+}$ activator similar to $\mathrm{CaM}$ (reviewed in [70]). However, some of these concepts have been challenged, and alternative views have been suggested, and it has been proposed that the relatively low $\mathrm{Ca}^{2+}$ affinity to fulfill in vivo working conditions may represent an evolutionary safety device to prevent 
4Fig. 3 Structure and function of the $\mathrm{Ca}^{2+}$ binding sites of m-calpain, $\alpha$-actinin, ATP/phosphate exchanger and calcineurin. a X-ray crystallographic structure of the rat m-calpain/calpain-2 dimer with $\mathrm{Ca}^{2+}$ bound in complex with the physiological inhibitor calpastatin at $2.4 \AA$ resolution. The structure was obtained from PDB: ID 3BOW. The EF-hand with $\mathrm{Ca}^{2+}$-bound (gray spheres), the loop forming the acidic electrostatic switch (AES) and domains IIa, IIb, III and IV in the large catalytic subunit (pink), and domain VI in the small regulatory subunit (blue) are indicated [66]. The red arrow shows the cleft between the two catalytic sub-domains IIa and IIb [66, 67]. A segment (B-peptide, residues 595-629) of calpastatin (brown) blocking the catalytic site in domains IIa and IIb is also shown [68, 212]. b $\mathrm{X}$-ray crystallographic structure of a human muscle $\alpha$-actinin-2 ( $\alpha$-Act-2) dimer (residues 16-874) at $3.5 \AA$ resolution is shown in pink and blue colors. The location of EF-hands 1 and 2 and the actinbinding domain (ABD) are indicated (left). Cryo-electron microscope derived structure of tandem calponin-homology domains (residues $1-109$ ) of human skeletal muscle $\alpha$-actinin-3 ( $\alpha$-Act-3) bound to a F-actin filament formed by G-actin subunits (residues 1-374) at $15 \AA$ resolution. Each calponin-1 homology domain $(\mathrm{CH})$ and actin subunit is represented in different colors (right). The structures were obtained from PDB ID: 4D1E and 3LUE, respectively [104, 213, 214]. c The CaM-like binding domain (CaM-BD), also denoted $\mathrm{Ca}^{2+}$ sensor, of human mitochondrial ATP/phosphate exchanger-1 (SCaMC-1) located at its $\mathrm{N}$-terminus is shown in a rainbow color code (residues 22-176). The four EF-hands bound to $\mathrm{Ca}^{2+}$ (gray sphere) and diethylene glycol molecule are indicated. The structure was obtained from PDB ID 4N5X [121]. d The figure depicts the calcineurin A (CaN-A, pink)/calcineurin $\mathrm{B}$ (CaN-B, blue) heterodimer in which the four EFhands of the regulatory $\mathrm{CaN}-\mathrm{B}$ subunit are saturated with $\mathrm{Ca}^{2+}$ (cyan spheres), and the calmodulin-binding site (CBS) of CaN-A (residues 391-414, dashed box) is already separated from the CaN-B binding region (residues 348-370) considered to be a calmodulin-like binding site (CLBS). Binding of the $\mathrm{Ca}^{2+} /$ calmodulin complex $\left(\mathrm{Ca}^{2+} / \mathrm{CaM}\right.$, rainbow color coded) to the CBS allows the C-terminal auto-inhibitory site (AIS) (residues 457-482) to be separated from the $\mathrm{Zn} / \mathrm{Fe}$ containing (brown spheres) catalytic site (residues 71-342) releasing the auto-inhibition and inducing full activation of the enzyme. The structures were obtained from PDB ID: 1AUI (human CaN-A/CaN-B heterodimer at $2.1 \AA$ resolution) [215] and 1CLL (human CaM at $1.7 \AA$ resolution) [216]. See text and Ref. [135] for more details on the activation mechanism

unwanted proteolysis (reviewed in [71]). The differential $\mathrm{Ca}^{2+}$ affinity of $\mu$-calpain and m-calpain is not due to differences in the sequence of the EF-hand $\mathrm{Ca}^{2+}$-binding sites which are almost $100 \%$ conserved, but it has been ascribed to differences in the $\mathrm{N}$-terminal and the $\mathrm{C}$-terminal EF-handcontaining domain IV of the $80 \mathrm{kDa}$ catalytic subunit, contributing $20-25 \%$ and $65 \%$, respectively, to the difference in $K_{d}$ for $\mathrm{Ca}^{2+}$ between the two calpain types as determined by mutagenesis studies [72].

Due to its high affinity for $\mathrm{Ca}^{2+}, \mu$-calpain can be isolated by $\mathrm{Ca}^{2+}$-dependent affinity chromatography using an immobilized peptide containing the CBS of the plasma membrane $\mathrm{Ca}^{2+}$-ATPase, indicative of the interaction between the CaM-LD of calpain with the CBS in analogy to CaM. However, the CaM-LD of the irreversibly inactivated protease only mildly activated the hydrolytic activity of the ATPase, in contrast to the strong effect exerted by $\mathrm{CaM}$ [73]. As deduced from the crystallographic structure of m-calpain in its $\mathrm{Ca}^{2+}$-free form, the CaM-LD is separated by a $\beta$-sandwich domain III also denoted C2-like domain, which binds phospholipids, participating together with potential non-EF-hand $\mathrm{Ca}^{2+}$-binding sites in a cooperative way during $\mathrm{Ca}^{2+}$-induced enzyme activation [68]. This structure also shows that in the absence of $\mathrm{Ca}^{2+}$ key amino acids in the catalytic site are separated by more than $10 \AA$, rendering the enzyme inactive, as more proximity is required to become active upon $\mathrm{Ca}^{2+}$ binding [67, 74]. Interestingly, a tissue-specific calpain homologue identified in Drosophila has an insert in the CaM-LD containing a hydrophobic segment, that likely participates in membrane attachment [75].

In addition to the CaM-LD found in the large subunit, the $30 \mathrm{kDa}$ subunit has two domains denoted V and VI, and the CaM-LD is located in domain VI [68] (Fig. 1), possibly contributing to $\mathrm{Ca}^{2+}$-induced activation of the complex. The CaM-LDs in both m-calpain subunits interact with $\mathrm{CaM}$ antagonists, in addition to $\mathrm{Ca}^{2+}$ [76]. Interestingly, the isolated CaM-LDs of the large subunits of $\mu$-calpain and $\mathrm{m}$-calpain and their small subunits all appear to dimerize in the absence of $\mathrm{Ca}^{2+}$, recovering their monomeric status upon addition of this cation [77]. This reversible association suggests the involvement of this region in the formation of active heterodimers and/or the formation of enzymatic oligomers. The crystallographic structure of the full-length $\mathrm{Ca}^{2+}$-free $\mathrm{m}$-calpain heterodimer reveals how $\mathrm{Ca}^{2+}$ binding to a highly negatively charged loop in domain III, denoted electrostatic switch, may induce the necessary molecular reorganization to create a functional catalytic center located between domains IIa and IIb [68] (Fig. 3a). In addition, $\mathrm{Ca}^{2+}$ could as well facilitate the binding of the enzyme to membranes, where the concentration of this cation is high, which may explain the low requirement for $\mathrm{Ca}^{2+}$ of this calpain isoform [66].

Calpains have various modulatory activities. An example of modulatory calpain action is the removing of the CaMbinding region of the plasma membrane $\mathrm{Ca}^{2+}$-ATPase inducing in this manner its CaM-independent activity [78, 79]. Very strikingly, both $\mu$-calpain and $\mathrm{m}$-calpain appear to have some preference to proteolyze CaM-binding proteins within regions enriched in proline, aspartic/glutamic acids, and serine/threonine residues, which are denoted PEST sequences (reviewed in [80]). The voracity of calpain for CaM-binding proteins is intriguing, and it could be speculated that the CBS of the target protein is the region recognized by the CaM-LD of the protease to recruit its targets acting as a surrogate of $\mathrm{CaM}$. In this context, it has been shown that the PEST domain of I $\mathrm{B} \alpha$, an inhibitor of the transcription factor NFKB, binds to the CaM-LD of $\mu$-calpain previous to its degradation by the protease. As a consequence, this allows the transfer of sequestered cytosolic NFkB to the nucleus and subsequent activation of gene transcription [81]. Nevertheless, the proteolytic capacity of calpain toward the 
CaM-binding proteins caldesmon and calponin does not depend on the CBS of those proteins, as deletion of these domains does not affect their cleavage by the protease [82].

Calpains are regulated by a physiological inhibitory protein denoted calpastatin, which requires $\mathrm{Ca}^{2+}$ for its function and is found in several isoforms, ranging in size from $\sim 19$ to $85 \mathrm{kDa}$ (reviewed in [61, 62]). Both, the CaM-LD of the $80 \mathrm{kDa}$ subunit of $\mu$-calpain and the one of the $30 \mathrm{kDa}$ subunit, participate in $\mathrm{Ca}^{2+}$-dependent calpastatin binding with very high affinity via one of their $\mathrm{N}$-terminal inhibitory repetitive acidic regions [83-85] (Fig. 3a). However, it is not yet clear how binding of the different inhibitory domains of calpastatin to the CaM-LD of calpain participate in the inhibition of its enzymatic activity [86]. The penta-peptide LSEAL, with high homology to conserved regions of calpastatin, binds to the CaM-LD of m-calpain and $\mu$-calpain mimicking the inhibition of calpastatin on the catalytic activity [87].

\section{Redox enzymes}

GPDH is a tetrameric enzyme that catalyzes the formation of glycerol-3-phosphate from dihydroxyacetone-phosphate, which is important for shuttling glycerol-3-phosphate across the inner mitochondrial membrane. This enzyme also has nitrosylase activity, and is strongly activated by $\mathrm{Ca}^{2+}$ enhancing the affinity of the enzyme for its substrate. It contains two EF-hand motifs (Fig. 1). However, one of them does not participate in $\mathrm{Ca}^{2+}$ binding. The presence of a lysine in this modified EF-hand prevents the binding of this cation. Moreover, this enzyme is not inhibited by $\mathrm{CaM}$ antagonists [88].

NADPH oxidases are membrane-bound enzymes involved in the generation of anion superoxide $\left(\mathrm{O}_{2}^{-}\right)$both in animal and plant cells. They are mainly involved in host defense, as for example inducing the so-called oxygen burst by leukocytes and macrophages. In addition, they participate in signaling processes, as exerted by their product and other ROS species (reviewed in $[89,90]$ ). Human NOX5 contains a CaM-LD located at its N-terminus with three canonical EFhands $\mathrm{Ca}^{2+}$-binding sites and an additional non-canonical EF-hand. The EF-hands 1 and 2 pair binds $\mathrm{Ca}^{2+}$ with low affinity, while the EF-hands 3 and 4 pair binds this cation with high affinity. The binding of $\mathrm{Ca}^{2+}$ to the CaM-LD activates the enzyme by interaction of this domain with the catalytic site [91]. In addition, the C-terminus of NOX5 contains a CaM-binding site. $\mathrm{Ca}^{2+}$-dependent $\mathrm{CaM}$ binding to this site increases the $\mathrm{Ca}^{2+}$ sensitivity of the $\mathrm{N}$-terminus CaMLD [92] (Fig. 1). Furthermore, in bovine aorta endothelial cells CaMK-II phosphorylates NOX5 at different Ser/Thr residues activating the enzyme, where phosphorylation of Ser475 appears to play a particular important role in the activation process, as determined by mutagenesis studies
[93]. In plants, NADPH oxidases are also known as respiratory burst oxidase homologues (RBOHs). In Arabidopsis six RBOHs were initially identified containing two EFhand $\mathrm{Ca}^{2+}$-binding sites located at the $\mathrm{N}$-terminal region $[94,95] . \mathrm{Ca}^{2+}$ binding to the EF-hands of these oxidases induces activation of the enzyme synergistically with a concomitant phosphorylation process [95, 96]. In rice $\mathrm{RBOH}$ two additional EF-hand-like motifs were identified. This enzyme is able to form dimers, where the two canonical EF-hands are swapped adopting the dimer a head-to-tail conformation, that together with the EF-hand-like motifs has a three-dimensional structure similar to calcineurin B and recoverin [97].

\section{The cytoskeleton protein a-actinin}

The group of CaM-LD-containing proteins is not restricted to the group of enzymes, but is extended to proteins with other functional roles, such as proteins with mechanical/ structural functions of the cytoskeleton. This underscores the functional versatility of CaM-LD proteins. In this section we will discuss the case of the cytoskeleton protein $\alpha$-actinin. $\alpha$-Actinin is a stick shape protein that crosslinks F-actin filaments forming bundles of stress fibers connected to focal adhesions. This multi-domain protein belongs to the spectrin family and is structurally organized with an N-terminal actin-binding domain (ABD), formed by two sequential calponin-homology domains, followed by a linker that connects four sequential spectrin repeat segments and a CaM-LD at its C-terminus (reviewed in $[98,99])$. In the case of $\alpha$-spectrin, of the two EF-hand motifs located in the C-terminus only the EF-hand closer to the spectrin repeat segments binds $\mathrm{Ca}^{2+}$ [100]. $\alpha$-Actinin makes anti-parallel homo-dimers through the formation of a ternary complex between the $\mathrm{N}$-terminal actin-binding domain plus the adjacent linker region of one monomer, and the C-terminal CaM-LD of the apposed monomer [101] (Fig. 3b). The CaM-LD has four EF-hand motifs that bind $\mathrm{Ca}^{2+}$ only in the non-muscle isoforms (1 and 4 ) while the muscle isoforms ( 2 and 3 ) lack the capacity to bind $\mathrm{Ca}^{2+}$ due to mutations in key amino acids involved in the coordination of this cation [102]. Structural data of the CaM-LD of $\alpha$-actinin-2 from Entamoeba histolytica in its native conformation obtained by NMR in the absence of $\mathrm{Ca}^{2+}$ shows that the linker region between the two lobes harboring the EF-hand motifs is flexible, as in the case of CaM [103]. In human $\alpha$-actinin- 2 similar NMR structural studies show that in the absence of $\mathrm{Ca}^{2+}$ the linker region is indeed flexible, but upon $\mathrm{Ca}^{2+}$ binding a stiffness of the linker region occurs limiting the rotation of the $\mathrm{N}$ - and C-terminal lobes leading to the loss of the capacity to crosslink actin through the juxtaposed actin-binding domain [104]. Modeling studies suggest that binding of the CaM-LD to the linker region regulates the distance between $\mathrm{F}$-actin and 
the actin-binding site of $\alpha$-actinin [105]. The gene coding for the $\alpha$-actinin-binding protein UDP- $N$-acetylglucosamine 2-epimerase/ $N$-acetylmannosamine kinase (GNE) is mutated in some congenital myopathies (reviewed in [106]). This enzyme binds with high affinity $\left(K_{d} \approx 9 \mathrm{nM}\right)$ to $\alpha$-actinin-2 and with tenfold lower affinity to $\alpha$-actinin- 1 . The CaM-LD of $\alpha$-actinin-2 participates in the interaction with GNE. Most relevant in connection with myopathies is the finding that the myopathic M743T mutation in GNE leads to a tenfold decrease of its affinity for $\alpha$-actinin-2 [107]. The $\alpha$-actininbinding protein palladin is part of the dense region of stress fibers and microfilaments where it plays an important role in the regulation of the actin cytoskeleton (reviewed in [108]). The interaction site of palladin has been mapped to the CaM-LD of $\alpha$-actinin [109]. In addition, it was shown that the interaction between palladin and $\alpha$-actinin is of functional importance as it plays a role in directing $\alpha$-actinin to specific subcellular foci.

In non-muscle cells $\alpha$-actinin bridges the actin filaments in the cytoskeleton but loses the capacity to bind actin when the concentration of $\mathrm{Ca}^{2+}$ exceed values above $0.1 \mu \mathrm{M}$ [99]. Based on structural data it has been proposed that $\mathrm{PIP}_{2}$ binds to the linker between the actin-binding domain and the first spectrin-like repeat of $\alpha$-actinin, and therefore it may regulate the interaction of its $\mathrm{CaM}-\mathrm{LD}$ to this linker region [110]. Cryo-electron microscopy reveals that in smooth muscle $\alpha$-actinin the CaM-LD of one monomer is oriented at approximately an angle of $90^{\circ}$ to the axis between the two calponin-homology domains of the appose monomer laying just between both of them [111]. By inference, the authors of this report proposed that binding of $\mathrm{Ca}^{2+}$ to the CaM-LD of non-muscle $\alpha$-actinin facilitates its interaction with the linker between the two calponin-homology domains separating both of them, and therefore explaining the loss of capacity to interact with actin in the presence of high calcium. Vinculin forms part of focal adhesions, and it has been shown that a segment of this adaptor protein, comprised between amino acids 1-258, interacts with the CaM-LD of smooth muscle $\alpha$-actinin [112]. NMR structural analysis of the CaM-LD of the major non-muscle $\alpha$-actinin-1 indicates that a single $\mathrm{Ca}^{2+}$ ion binds to the $\mathrm{N}$-lobe of this domain [104]. Based on this structure, these authors proposed a model for the regulation of the interaction between $\alpha$-actinin and actin confirming the above-proposed view that $\mathrm{Ca}^{2+}$ works negatively on this interaction by stabilizing the actin binding sites. $\alpha$-Actinin also participates in linking transmembrane receptors, channels and other signaling proteins to the cytoskeleton, regulating in this manner a variety of signaling pathways (reviewed in [99, 113]). $\alpha$-Actinin-4 contains a domain that interacts with nuclear receptors, such as estrogen receptor- $\alpha(E R \alpha)$. This potentiates its transcriptional activity. However, when the CaM-LD of $\alpha$-actinin, which is required to interact with histone deacetylase- 4 , is lacking its co-activator activity is lost [114]. The CaM-LD of $\alpha$-actinin also interacts with the long $\mathrm{C}$-terminal tail of adenosine $A_{2 A}$ receptor $\left(A_{2 A} R\right)$ in the absence of $\mathrm{Ca}^{2+}$. This fixes the receptor to the actin cytoskeleton, as $\alpha$-actinin acts as a bridging molecule, and participates in receptor internalization upon ligand binding. When the cytosolic $\mathrm{Ca}^{2+}$ concentration rises, $\mathrm{Ca}^{2+} / \mathrm{CaM}$ binds to the site where the CaM-LD of $\alpha$-actinin binds to the receptor because of its higher affinity. This reduces ligand-dependent $A_{2 A} R$ internalization and its detachment from the cytoskeleton [115].

The $\alpha$-actinin isoforms expressed in striated muscle are localized at the Z-disk and analogous dense bodies. They crosslink the actin filaments of adjacent sarcomeres to hold them together forming a stabilizing lattice in the contractile apparatus (reviewed in $[98,99]$ ). The C-lobe of the CaMLD of muscle $\alpha$-actinin interacts with a region close to the $\mathrm{N}$-terminus of titin, a gargantuan filamentous $\sim 3 \mathrm{MDa}$ protein expanding the sarcomere from the Z-disk to the M-line. This interaction induces a structural change of the titin $/ \alpha$ actinin-binding region into a helical conformation, participating in this manner in the assembly of the Z-disk as shown by NMR analysis using the CaM-LD sequence of $\alpha$-actinin and a Z-repeat of titin [116]. The interaction of the CaM-LD with the Z-repeat of titin is very weak and changes depending on the angle in which the force is applied using optical tweezers at a single molecular level. Therefore, a model was proposed in which multiple cooperative interactions are required to attain stable titin anchoring to the Z-disk while individual components are dynamically exchanged [117]. The three-dimensional structure of muscle $\alpha$-actinin has shown that upon $\mathrm{Ca}^{2+}$ binding the C-terminal CaM-LD gets close to the linker region between the two calponinhomology domains forming the actin-binding region. This suggests a $\mathrm{Ca}^{2+}$-dependent interaction of $\alpha$-actinin with the actin filaments [118] as later also shown for non-muscle $\alpha$-actinin [111], described above.

\section{Other CaM-LD proteins}

The mitochondrial inner membrane has an ATP transport system unrelated to the ATP/ADP exchanger, and is hence insensitive to the ATP/ADP translocase inhibitor atractyloside [119]. This transporter was identified as an ATP-Mg/ phosphate exchanger, with at least eleven isoforms in mammals that are denominated SCaMCs. It has highly conserved orthologues in lower eukaryotes as for example in yeast (denoted Sal1p). It is positively regulated by micromolar levels of $\mathrm{Ca}^{2+}$ and contain six transmembrane segments and an N-terminal extension corresponding to a CaM-LD with four EF-hands (Fig. 3c), although some isoforms lack one or several of these EF-hand motifs. The CaM-LD of SCaMC faces the space between the inner and outer mitochondrial membrane and therefore senses the $\mathrm{Ca}^{2+}$ concentration that 
is at equilibrium with the cytosol (reviewed in [119]). The $\mathrm{N}$-terminal extension of SCaMC1 (NTD) comprising the first 193 amino acids has been crystallized in its $\mathrm{Ca}^{2+}$-bound form showing that the EF-hands are sequestered by an endogenous helical segment in a compact structure [120]. NMR studies indicate that the apo-NTD could interact with the transmembrane domain [121]. The carrier works as an electroneutral exchanger between ATP-Mg and divalent phosphate. Although it is able to work in both directions, the net influx and efflux of ATP into the mitochondria depends on the $\mathrm{pH}$ in the medium, as the uptake of phosphate into the mitochondria is driven by the $\mathrm{pH}$ gradient (alkaline inside), and the chemical potential of phosphate secondarily drives ATP-Mg uptake in exchange for phosphate exit (reviewed in [119]). At least three ATP/phosphate exchangers exist in Arabidopsis. Interestingly, in vitro analysis shows that the three isoforms prefer ATP-Ca, over of ATP-Mg, exchanged by phosphate [122]. From mutagenesis experiments, it was concluded that the $\mathrm{Ca}^{2+}$ effect on ATP transport is not primarily dependent on the CaM-LD of these transporters.

COMP, also named thrombospondin-5, is a pentameric $\mathrm{Ca}^{2+}$-binding glycoprotein of the cartilage extracellular matrix that interacts with multiple other proteins of the extracellular matrix, including growth factors, integrins and extracellular proteases among others (reviewed in [123, 124]). COMP forms a lattice to present the growth factors to the cells, participating in this manner in chondrogenesis (reviewed in [125]). Its structure comprises an N-terminal domain followed by four EGF-like repeats, eight CaM-like repeats and a globular C-terminal region. The five thrombospondin family members contain similar $\mathrm{Ca}^{2+}$-binding repeats, although the general structure of these proteins and their oligomerization status differ (reviewed in [123, 124]). COMP/thrombospondin-5 is particularly abundant surrounding the chondrocytes. Interestingly, mutations or single amino acid deletions affecting their CaM-like domains most likely in their $\mathrm{Ca}^{2+}$-binding capacity are responsible for the occurrence of pseudoachondroplasia and multiple epiphyseal dysplasias in humans. These are autosomal dominant congenital conditions characterized by short limbs and hands, ligament laxity and scoliosis among other skeletal anomalies leading to the onset of osteoarthrosis [126-128].

Genes coding for atypical short class XIV myosins (type A and B) were found in three species of Plasmodium. These proteins contain a conserved catalytic head that binds actin and hydrolyzes ATP, and a neck region, however lacking the characteristic tail region of other myosins. These class XIV myosins are expressed during the motile stages of the parasite implying a functional role during the invasion process. The light-chain of myosin-B contains a CaM-LD at its C-terminus that has similarity to other EF-hand proteins such as CaM. However, this protein does not bind $\mathrm{Ca}^{2+}$, as inferred from the lack of change in the circular dichroism spectrum upon addition of this cation. The CaM-LD of myosin-light chain-B interacts with the neck region of myosin-B. Blast analysis of the genome of $T$. gondii shows that the sequence of this CaM-LD is conserved in a related myosin-B lightchain [129].

Clonorchiasis is a liver infestation by the planaria worm Clonorchis sinensis that is transmitted by contaminated food. Tegumental proteins in the outer surface membrane of this parasite are vital for its physiology and therefore interesting targets for vaccine development. A tegumentalallergen-like protein (CsTAL3) has been identified in this worm containing a CaM-LD at its $\mathrm{N}$-terminus and a dynein light chain-like domain at its C-terminus. The CaM-LD has

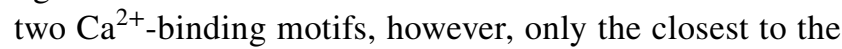
$\mathrm{N}$-terminus binds $\mathrm{Ca}^{2+}$. Proteins with similar CaM-LDs were identified in Schistosoma mansoni, another pathogenic worm. CsTAL3 is antigenic and implicated in the host immune response mediated by IgA but not IgG. The crystal structure of this protein has been described [130].

FSH is a heterodimeric hormone synthesized in the anterior pituitary gland that regulates growth, development, maturation and reproductive processes in both males and females in concert with other hormones. Using a battery of synthetic peptides corresponding to the sequence of the $\beta$-subunit of human FSH to study receptor interaction, it was uncovered that a peptide, corresponding to amino acids 1-15 of the hormone was able to bind $\mathrm{Ca}^{2+}$ and presents similarities in affinity to the third EF-hand of CaM [131]. The authors of this report suggested that this $\mathrm{Ca}^{2+}$-binding site may participate in the interaction of the hormone with its receptor. Whether the binding site of this peptide in the receptor is a non-canonical CaM-LD, although likely, remains an open issue. Another intriguing issue not yet clarified, is whether there is any physiological relevance to the fact that this peptide was able to form transmembrane $\mathrm{Ca}^{2+}$ channels in liposomes.

\section{Calmodulin-binding proteins with non-EF-hand calmodulin-like binding sites (CLBSs)}

In this section, we will discuss different types of proteins, unrelated to the phylogenetic origin of those discussed in the previous section, in which gene fusion events appear to be the origin. It refers to the existence of regions in CaM-binding proteins that are proposed to interact with their CBS in the absence of CaM. These regions, lacking EF-hand motifs but having binding properties similar to $\mathrm{CaM}$, are generally anionic and are denoted CaM-like binding sites (CLBSs), in contrast to the CBSs that are rich in basic residues. The CLBSs are predicted to bind the potent $\mathrm{CaM}$ antagonist melittin, which is present in bee venom. 
Several CaM-binding enzymes, including MLCK, phosphofructokinase, phosphorylase $\mathrm{b}$ kinase, plasma membrane $\mathrm{Ca}^{2+}$-ATPase and CaMK-II have been proposed to comply with these criteria as their putative CLBSs were identified [20]. Nevertheless, experimental evidence for this assertion is lacking for some of these proteins, including CaMK-II and MLCK. In this section we also include calcineurin, where the CBS and CLBS are located in distinct subunits. As discussed by Jarrett and Madhavan [20], the functional role of the CLBS is to exert an auto-inhibitory function by blocking the CBS. In addition, a flip-flop model for CaMbinding enzyme activation was proposed, where shuttling between the inactive form of the enzyme (CBS occupied by the CLBS) and the active conformation (CBS occupied by $\left.\mathrm{Ca}^{2+} / \mathrm{CaM}\right)$, was envisioned. This also explains why the proteolytic removal of the CBS of some enzymes induces their activation in the absence of $\mathrm{CaM}$, as for example in the PMCA when proteolyzed by trypsin [132], or in a more physiological setting by calpain $[78,79,133]$. In what follow we will discuss some of those "old" CLBS containing proteins as well as some newly discovered and analyzed examples. Table 4 shows collected data on the amino acid sequences of the CBS and CLBS of selected proteins containing non-EF-hand CLBSs.

\section{The protein phosphatase calcineurin}

The CaM-dependent serine/threonine phosphatase calcineurin (also denoted protein phosphatase $2 \mathrm{~B}$ ) is representative of heterodimeric proteins with a CBS and CLBS located in distinct subunits (Fig. 3d). Melittin interacts with calcineurin, indicative that this CaM-binding peptide binds to
Table 4 The CBS and CLBS from selected non-EF-hand proteins

\begin{tabular}{|c|c|c|c|c|}
\hline $\begin{array}{l}\text { Protein } \\
\text { (activity) }\end{array}$ & Species & Domain & Sequence & $\begin{array}{l}\text { Ref. } \\
\text { UniProt } \\
\text { ID }\end{array}$ \\
\hline $\begin{array}{c}\mathrm{Ca}^{2+} \text {-ATPase, isoform } 1 \\
\text { (plasma membrane }) \\
\left(\mathrm{Ca}^{2+} \text { transport }\right)\end{array}$ & $\begin{array}{l}\text { Human } \\
\text { (Homo } \\
\text { sapiens) }\end{array}$ & $\begin{array}{l}\text { CBS } \\
\text { CLBS }\end{array}$ & $\begin{array}{l}{ }^{109{ }^{8}} \text { RELRRGQILWFRGLNRIQTQIRVVNAFRSSLYEG }{ }^{1131} \\
{ }^{659} \mathrm{EPEPEWDNENDIVTGLTCIAVVGIEDP}\end{array}$ & $\begin{array}{r}{[20,186]} \\
P 20020\end{array}$ \\
\hline $\begin{array}{c}\text { CaMK-II } \beta \text {-subunit } \\
\text { (Ser/Thr-protein kinase) }\end{array}$ & $\begin{array}{c}\text { Rat } \\
\text { (Rattus } \\
\text { norvegicus) }\end{array}$ & $\begin{array}{l}\text { CBS } \\
\text { CLBS }\end{array}$ & $\begin{array}{l}\text { 292KKFNARRKLKGAILTTMLATRNFSVGR }^{318} \\
{ }^{214} \text { WDEDQHKLYGGIKAGAYDFPSPEWD }{ }^{238}\end{array}$ & $\begin{array}{r}{[20,278]} \\
\mathrm{P} 08413\end{array}$ \\
\hline $\begin{array}{c}\text { EGFR/ErbB1 } \\
\text { (Tyr-kinase receptor) }\end{array}$ & $\begin{array}{l}\text { Human } \\
\text { (Homo } \\
\text { sapiens) }\end{array}$ & $\begin{array}{l}\text { CBS } \\
\text { CLBS } \\
\left({ }^{a}\right)\end{array}$ & $\begin{array}{l}{ }^{645} \text { RRRHIVRKRTLRRLLQ660 } \\
\text { 979 DEEDMDDVVDADEY }^{992}\end{array}$ & $\begin{array}{c}{[164,} \\
169] \\
\text { P00533 }\end{array}$ \\
\hline $\begin{array}{c}\text { ErbB2 } \\
\text { (Tyr-kinase receptor) }\end{array}$ & $\begin{array}{l}\text { Human } \\
\text { (Homo } \\
\text { sapiens) }\end{array}$ & $\begin{array}{l}\text { CBS } \\
\text { CLBS } \\
\text { (a) }\end{array}$ & $\begin{array}{l}{ }^{656} \mathrm{RRQQKIRKYTMRRLL} \mathrm{Q}^{671} \\
{ }^{989} \mathrm{EDDDMGDLVDAEEY} \mathrm{Y}^{1002}\end{array}$ & $\begin{array}{c}{[169} \\
181] \\
\text { P04626 }\end{array}$ \\
\hline $\begin{array}{c}\text { ErbB3 } \\
\text { (Tyr-kinase receptor, } \\
\text { null activity) }\end{array}$ & $\begin{array}{l}\text { Human } \\
\text { (Homo } \\
\text { sapiens) }\end{array}$ & $\begin{array}{l}\text { CBS } \\
\text { CLBS } \\
\left({ }^{(a)}\right.\end{array}$ & $\begin{array}{l}{ }^{648} \text { RGRRIQNKRAMRRYLE } \\
\text { 982 EEVELEPELDLDLD }\end{array}$ & $\begin{array}{c}{[169]} \\
\text { P21860 }\end{array}$ \\
\hline $\begin{array}{c}\text { ErbB4 } \\
\text { (Tyr-kinase receptor) }\end{array}$ & $\begin{array}{l}\text { Human } \\
\text { (Homo } \\
\text { sapiens) }\end{array}$ & $\begin{array}{l}\text { CBS } \\
\text { CLBS } \\
\left({ }^{a}\right)\end{array}$ & $\begin{array}{l}{ }^{651}{ }^{\text {RRKS IKKKRALRRFLE }}{ }^{666} \\
{ }^{84} \mathrm{DEEDLEDMMDAEEY}{ }^{997}\end{array}$ & $\begin{array}{l}{[169]} \\
\text { Q15303 }\end{array}$ \\
\hline $\begin{array}{c}\text { MLCK skeletal muscle } \\
\text { (Ser/Thr-protein } \\
\text { kinase) }\end{array}$ & \begin{tabular}{|c} 
Rabbit \\
(Oryctolagus \\
cuniculus)
\end{tabular} & $\begin{array}{l}\text { CBS } \\
\text { CLBS }\end{array}$ & $\begin{array}{l}{ }^{578} \text { KRRWKKNFIAVSAANRFKKISSSGALM }{ }^{604} \\
{ }^{493} \text { PFLGDDDTETLNNVLSGNWYFDEETFEAVSD }{ }^{523}\end{array}$ & $\begin{array}{l}{[20,279]} \\
\text { P07313 }\end{array}$ \\
\hline $\begin{array}{c}\mathrm{NHE} 1 \\
\left(\mathrm{Na}^{+} / \mathrm{H}^{+} \text {exchange }\right)\end{array}$ & $\begin{array}{l}\text { Human } \\
\text { (Homo } \\
\text { sapiens) }\end{array}$ & $\begin{array}{l}\text { CBS } \\
\text { CLBS }\end{array}$ & $\begin{array}{c}{ }^{622} \text { ALSKDKEEEIRKILRNNLQKTRQRLRSYNRHTLVADPYEEA } \\
\text { WNQMLLRRQKARQLEQKINNYLTVPAHK } \\
\text { 753EEDEDDD } \\
759\end{array}$ & $\begin{array}{c}{[191]} \\
\text { P19634 }\end{array}$ \\
\hline $\begin{array}{l}\text { Phosphofructokinase } \\
\text { (sugar kinase) }\end{array}$ & $\begin{array}{l}\text { Rabbit } \\
\text { (Oryctolagus } \\
\text { cuniculus) }\end{array}$ & $\begin{array}{l}\text { CBS } \\
\text { CLBS }\end{array}$ & \begin{tabular}{|l|}
${ }^{372}$ KLRGRSFMNNWEVYKLLAHIRPPAPKSGSYTVAVM \\
24106 DEWNDDPPCEPIFVWDAGCSLSTVLALYGCHRGMVELVFT
\end{tabular} & $\begin{array}{l}{[20,162]} \\
\text { P00511 }\end{array}$ \\
\hline $\begin{array}{l}\text { Phosphorylase b } \\
\text { kinase, } \alpha \text {-subunit } \\
\text { regulatory } \\
\text { (Ser/Thr-protein } \\
\text { kinase) }\end{array}$ & $\begin{array}{l}\text { Rabbit } \\
\text { (Oryctolagus } \\
\text { cuniculus) }\end{array}$ & $\begin{array}{l}\text { CBS1 } \\
\text { CLBS1 } \\
\text { CBS2 } \\
\text { CLBS2 }\end{array}$ & $\begin{array}{c}{ }^{{ }^{813} \text { LYGKVGKIRHWGLIRYISGILRKKVEAL }}{ }^{840} \\
{ }^{627} \text { LYSEDYDDNYDELESGDWMDGY } \\
\\
\text { 1064 RQGQWQRRRRLDGALNRVPIGFYQKWKVLQK }^{1095} \\
\text { 321 FENIECEWPLFWTYFILDGVFSGNAEQVQEYREALEAVLI }^{360}\end{array}$ & $\begin{array}{c}{[20} \\
157] \\
\mathrm{P} 18688\end{array}$ \\
\hline $\begin{array}{l}\text { Phosphorylase b } \\
\text { kinase, } \beta \text {-subunit } \\
\text { regulatory } \\
\text { (Ser/Thr-protein } \\
\text { kinase) }\end{array}$ & $\begin{array}{l}\text { Rabbit } \\
\text { (Oryctolagus } \\
\text { cuniculus) }\end{array}$ & $\begin{array}{l}\text { CBS1 } \\
\text { CLBS } \\
\text { CBS2 }\end{array}$ & $\begin{array}{l}{ }^{768} \text { RLYRRAGSKKLWLAVRYGAAFTQKFSSS }{ }^{795} \\
\text { 673ISDTEELPEFKSFEELE } \\
\text { 689 } \\
\text { 919NGRCWLNKRQIDGSLNRTPTGFYDVWQILER }{ }^{951}\end{array}$ & $\begin{array}{c}{[20} \\
154] \\
\mathrm{P} 12798\end{array}$ \\
\hline $\begin{array}{l}\text { Phosphorylase b } \\
\text { kinase, } \gamma \text {-subunit } \\
\text { catalytic } \\
\text { (Ser/Thr-protein } \\
\text { kinase) }\end{array}$ & $\begin{array}{l}\text { Rabbit } \\
\text { (Oryctolagus } \\
\text { cuniculus) }\end{array}$ & $\begin{array}{l}\text { CBS } \\
\text { CLBS } \\
\left({ }^{b}\right)\end{array}$ & $\begin{array}{l}{ }^{294} \text { GKFKVICLTVLASVRIYYQYRRVKP } \\
{ }^{296} \mathrm{EEVVYQQFFPHALAEEATYRKQPQVVLFRSVLDKVTDSYDD} 250\end{array}$ & $\begin{array}{l}{[20,280]} \\
P 00518\end{array}$ \\
\hline
\end{tabular}

Basic amino acids (blue) and acidic amino acids (red) are indicated. $C B S$ calmodulin-binding site, CaMK-II calmodulin-dependent protein kinase, CLBS calmodulin-like binding site, EGFR epidermal growth factor receptor, $\operatorname{ErbB1/2/3/4}$ erythroblastic leukemia viral oncogene homologues 1, 2, 3 and 4, $M L C K$ myosin light chain kinase

${ }^{\text {a }}$ Sequence position of the mature receptor lacking the signal peptide

${ }^{\mathrm{b}}$ The CaM-BD sequence in UniProt P00518 starts at position 302; and the CaM-LD sequence lacks of the amino acid residues LDKV (underlined) 
CLBS that interacts with the CBS as described above and in Fig. 3d [20]. This phosphatase regulates multiple cellular functions, best studied is the dephosphorylation of the transcription factor NFAT inducing its nuclear translocation to initiate its transcriptional program (reviewed in [134]). This enzyme is also target of immunosuppressive drugs used in the clinic, such as cyclosporin A and FK506 (tacrolimus) (reviewed in [135, 136]). Calcineurin is formed by a $60 \mathrm{kDa}$ catalytic subunit ( $\mathrm{CaN}-\mathrm{A})$ that binds calmodulin, and a $19 \mathrm{kDa}$ regulatory subunit denoted CaN-B with four EFhands $\mathrm{Ca}^{2+}$-binding sites (see Figs. 1, 3d). CaN-B is myristoylated at its N-terminus (reviewed in [137]) and has structural similarity to $\mathrm{CaM}$ [138]. At low $\mathrm{Ca}^{2+}$ concentration the binding of $\mathrm{Ca}^{2+}$ to the two high-affinity sites of CaN-B maintains the CBS of CaN-A bound to a CLBS located in the same subunit, allowing auto-inhibition. At high $\mathrm{Ca}^{2+}$ concentration the low-affinity $\mathrm{Ca}^{2+}$ binding sites at CaN-B are also occupied and the CBS dissociates from this site. Thereafter, $\mathrm{Ca}^{2+} / \mathrm{CaM}$ binds to the CBS in CaN-A displacing an auto-inhibitory domain located at the $\mathrm{C}$-terminus of its catalytic site yielding the fully active enzyme (reviewed in $[135,136,139])$. Apparently, a disordered fragment of the auto-inhibitory domain blocks access to the catalytic site playing a central role in the auto-inhibition mechanism [140]. Recent structural studies on the interaction of CaM with a peptide corresponding to $\mathrm{CaN}-\mathrm{A}$ further refined this model for the activation of calcineurin by $\mathrm{Ca}^{2+} / \mathrm{CaM}$ and its regulatory subunit [141]. However, the CaN-A $\beta 1$ isoform shows a distinct non-canonical regulation by $\mathrm{Ca}^{2+}$ and $\mathrm{CaM}$, as it lacks an auto-inhibitory domain but a four amino acid motif $\left({ }^{462} \mathrm{LAVP}^{465}\right)$ competitively inhibits the enzyme conferring basal and $\mathrm{Ca}^{2+}$-dependent activity decreasing its need of CaM [142]. Using luminescent lanthanides, as surrogate cations for $\mathrm{Ca}^{2+}$, it was demonstrated that the highest affinity for $\mathrm{Tb}^{3+}$ is located in the C-terminal region of CaN-B [143]. Using ${ }^{113} \mathrm{Cd} \mathrm{NMR}$ and $\mathrm{Ca}^{2+}$ flow-dialysis the existence of a single EF-hand with high affinity for $\mathrm{Ca}^{2+}$ (close to $10 \mathrm{nM}$ ) and three others of lower affinity (close to $10 \mu \mathrm{M}$ ) were identified [144]. Mutational inactivation of CaN-B impairing $\mathrm{Ca}^{2+}$-binding to EF-hands 1, 2 and 3, but not EF-hand 4, has shown that these sites are required for the catalytic activity of CaN-A in the absence of CaM, with an essential role of EF-hand 2. Moreover, eliminating the $\mathrm{Ca}^{2+}$-binding capacity of EF-hand 2 on CaN-B decreases the affinity of CaM for CaN-A at low $\mathrm{Ca}^{2+}$ concentration [145].

\section{Kinases}

CaMK-II is a ubiquitous and multifunctional CaM-dependent kinase, activated by autophosphorylation in a $\mathrm{Ca}^{2+} /$ CaM-dependent way that also contains an acidic CLBS (Fig. 1). CaMK-II mediates $\mathrm{Ca}^{2+}$ signals by phosphorylating numerous targets important for signaling processes leading to synaptic plasticity, ion homeostasis, transcription and immunoregulation among many other processes (reviewed in [146, 147]). Due to its multimeric structure and autoregulation, it is able to switch into a form, which is no more dependent of initial $\mathrm{Ca}^{2+} / \mathrm{CaM}$ as autophosphorylation increases the affinity to $\mathrm{CaM}$ by a factor of 1000 , slowing the release of $\mathrm{Ca}^{2+} / \mathrm{CaM}$, and therefore, it is able to participate in learning and memory function [148]. CaMKII exists in four isoenzymes and 30 splice forms, which determine its specific localization, activation mechanism and target interaction/phosphorylation. This kinase forms a dodecameric complex, and each monomer has a $\mathrm{N}$-terminal kinase domain followed by a regulatory segment, a short linker region and a hub domain. Jarrett and Madhavan [20] compared a number of CaM-binding proteins and found that CaMK-II and skeletal and smooth muscle MLCK (described below) among others bind to melittin, and as melittin is a well-known target of CaM they proposed the existence of a putative CLBS. In the two kinases, the CLBS with the main characteristic of having minimally two regions containing acidic residues adjacent to hydrophobics and aromatics among the hydrophobics one could be identified. The authors [20], predicted CLBS sequences based on their proposed potential to interact with the CBS. They found a striking alignment of the CBS (with positive charges) and CLBS (with negative charges) for both CaMK-II and MLCK (Table 4), suggesting that these sites could interact electrostatically inhibiting the enzymatic activity in the absence of $\mathrm{Ca}^{2+} / \mathrm{CaM}$. Nevertheless, the dodecameric structure of the auto-inhibited human CaMK-II holoenzyme contradicts this model, as the autoinhibitory domains of the complex are docked to the central hub, in which the CaM-binding sites are located. $\mathrm{Ca}^{2+} / \mathrm{CaM}$-binding displaces the regulatory segment allowing auto-phosphorylation and activation of the enzyme [149]. As the CaM-binding site in the inactive form is inaccessible according to this structure and as mentioned previously is contiguous to a distinct autoinhibitory domain (Fig. 4a, b), it is therefore questionable whether the CLBS interacts with the CBS in CaMK-II to induce autoinhibition.

MLCK is another $\mathrm{Ca}^{2+} / \mathrm{CaM}$-dependent kinase containing a potential CLBS only predicted because of its interaction with melittin, and as for CaMK-II it was proposed to play an inhibitory role [20]. Figure 1 shows the domains in MLCK and Fig. $4 \mathrm{c}$ the location of the major CBS and CLBS of MLCK-2. This kinase is most known as an essential part of the regulation of smooth muscle contraction through phosphorylation of regulatory myosin II light chains. However, the smooth muscle MLCK is also found in many other cells involved in cell motility processes driven by myosin II. There exists also a skeletal and a heart muscle-specific MLCK form, expressed from different genes. Next to the catalytic domain on both sides, $\mathrm{Ca}^{2+} / \mathrm{CaM}$-binding domains are found and a myosin binding domain is placed at the 
A
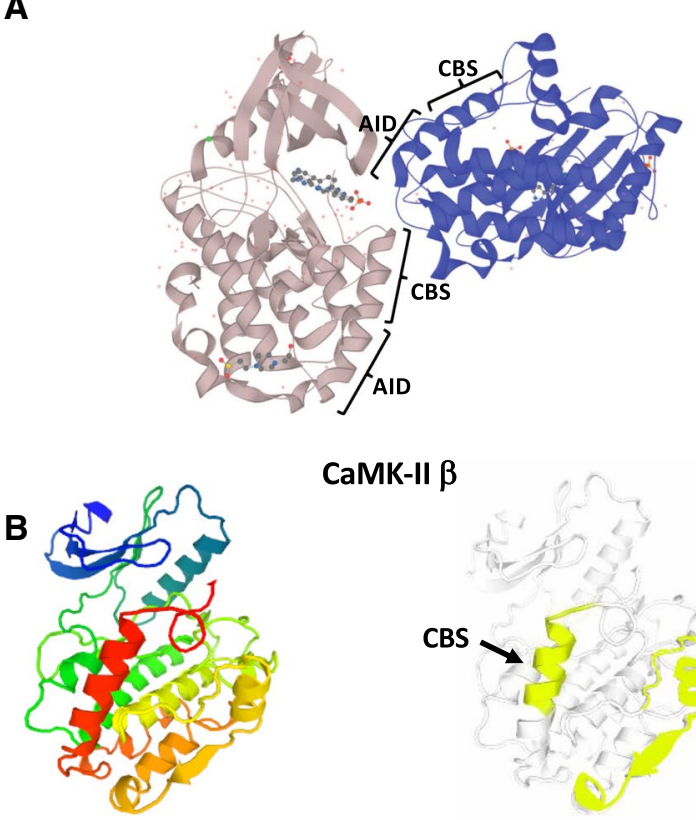

СаMK-II $\beta$

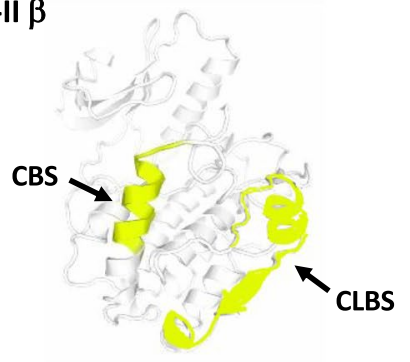

C

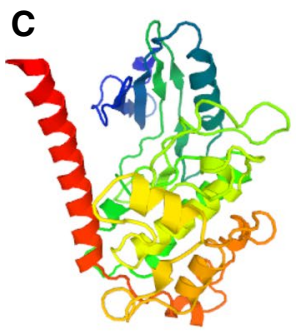

MLCK-2

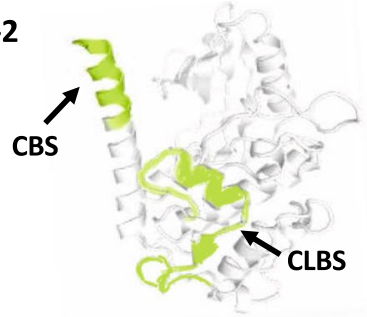

Fig. 4 Structure and CBS/CLBS location in CaMK-II and MLCK. The figure depicts two chains of the autoinhibited dodecameric human CaMK-II $\delta$ isoform showing the contiguous autoinhibitory domain (AID) and CBS in both chains (a); the X-ray crystallographic structure and the location of the calmodulin-binding domain (CBS) and calmodulin-like binding site (CLBS) of the $\beta$-subunit of calmodulin-dependent protein kinase-II (CaMK-II) from rat (b); and myosin light-chain kinase-2 (MLCK-2) from rabbit skeletal/cardiac muscle showing the CBS and CLBS (c). In panels $\mathbf{b}$ and $\mathbf{c}$ left the structures are shown using a rainbow color code going from the $\mathrm{N}$-terminal (blue) to the C-terminal (red), and in panels $\mathbf{b}$ and $\mathbf{c}$ right highlighting in color the CBS and CLBS. In panel a two chains of CaMK-II are shown in different colors. Crystallographic 3D models for rat and human CaMK-II at $2.3 \AA$ resolution (P08413 KCC2B_RAT based on template 2vn9A, residue range 10-309, and Q13557 KCC2D_ HUMAN based on template $2 \mathrm{vn} 9$, residue range 11-309), and rabbit MLCK-2 at 2.2 A resolution (P07313 MYLK2_RABIT based on template $2 \times 0 \mathrm{gA}$, residue range 290-596) were taken and modified from UniProt SWISS-MODEL database

C-terminus. In smooth muscle MLCK, one CBS is located in the $\mathrm{N}$-terminus and another major CBS in the $\mathrm{C}$-terminus distal of the catalytic site [150]. An actin-binding domain exists in the N-terminal region but only in the smooth muscle form, which keeps the enzyme in place. For becoming active MLCK has to be phosphorylated by the c-Src kinase

following $\mathrm{Ca}^{2+} / \mathrm{CaM}$ binding. This leads to autophosphorylation on 19 serine and threonine residues resulting in actin-myosin cross-bridging needed for smooth muscle contraction (reviewed in $[151,152]$ ). In addition to c-Src, the tyrosine kinase c-Abl phosphorylates non-muscle MLCK inducing its activation [153]. As in the case CaMK-II the autoinhibitory site has been localized close to the CBS, and experimental evidence for CBS/CLBS interaction is lacking. However, it could be speculated that the CLBS in these kinases may bind to a CBS during structural transition states in activation/inactivation of the same polypeptide or other subunits.

Phosphorylase $\mathrm{b}$ kinase is a multimeric $\mathrm{Ca}^{2+} / \mathrm{CaM}$ regulated enzyme that changes the poorly active glycogen phosphorylase $\mathrm{b}$ into a more active conformation (forma) that catalyzes the release of glucose-1-phosphate from glycogen to fuel sugar metabolism. The three subunits $(\alpha$, $\beta, \gamma)$ of phosphorylase b kinase constitutively bind CaM (denoted integral $\delta$ subunit) [154-157]. These subunits also have acidic regions that could represent CLBSs [20]. The CBS located in the catalytic $\gamma$ subunit was found to interact with the regulatory $\alpha$ subunit that has an inhibitory function [158]. This suggests that this interaction may play an auto-inhibitory role when $\mathrm{CaM}$ ( $\delta$ subunit) is free of $\mathrm{Ca}^{2+}$. Nevertheless, a demonstration of direct CBS/CLBS interaction in the whole enzyme is lacking.

Phosphofructokinase is a key rate-limiting allosteric enzyme in glycolysis that catalyzes the phosphorylation of fructose-6-phosphate resulting in fructose-1,6-bisphosphate. In mammals, it forms homo-tetramers, and the formation of active tetramers is negatively regulated by $\mathrm{Ca}^{2+} / \mathrm{CaM}[159$, 160]. Phosphofructokinase, together with hexokinase, pyruvate kinase and lactic dehydrogenase, is overexpressed in tumor cells and responsible for the high rate of aerobic glycolysis also called the Warburg effect [161]. The identified CBS was found to be located in the region where two dimers interact to form tetramers. The binding of $\mathrm{Ca}^{2+} / \mathrm{CaM}$ stabilizes the inactive dimer, allowing in this manner an inactiveactive equilibrium following the dimer-tetramer status of the enzyme $[162,163]$. Phosphofructokinase also has a CLBS, and the CBS in one subunit of the enzyme was proposed to interact with the CLBS in another subunit contributing to maintaining the stability of the tetramer [20].

We have demonstrated that the EGFR is a $\mathrm{Ca}^{2+}$-dependent CaM-binding protein containing a CBS located at the cytosolic juxtamembrane region [164-166]. We also demonstrated that $\mathrm{Ca}^{2+} / \mathrm{CaM}$ appears to participate in the liganddependent activation of the receptor in living cells [167], and that phospho-Tyr-CaM is a positive regulator of the EGFR when activated by its ligand [168]. We also noticed the existence of a potential CLBS in the receptor due to its acidic nature $\left({ }^{979}\right.$ DEEDMDDVVDADEY $\left.{ }^{992}\right)$ and relative sequence similarity to a segment of CaM located at its 
C-terminus $\left({ }^{118}\right.$ DEEVDEMIREADI $\left.{ }^{130}\right)$, suggesting that it may interact with the CBS of the receptor [169] (Table 4). Figure 5a shows the location of the CLBS in the cytosolic region of the receptor $\left(E_{\text {GFR }}\right)$. Modeling studies further suggested that indeed the electrostatic interaction between CBS and CLBS in the EGFR is sterically possible and that it could facilitate the stabilization of its dimers upon ligand binding [170-172] (reviewed in [173]). Figure 5b depicts a model where hetero-CBS/CLBS interaction stabilizes the ligand-bound EGFR dimer. The CLBS is located distal to the tyrosine kinase domain and within the $\mathrm{Ca}^{2+}$ internalization (CAIN) domain which is implicated in $\mathrm{Ca}^{2+}$ mobilization and receptor internalization (reviewed in [174]). However, direct experimental evidence of interaction between the CBS and the CLBS of the EGFR is lacking.

A series of 89 human glial tumors, including grade IV glioblastomas, grade III anaplastic astrocytomas and grade II astrocytomas, were analyzed for mutations affecting the coding regions of the CBS and CLBS of the EGFR and other ErbB family members $[175,176]$. No point mutations were detected affecting the analyzed domains in any of the ErbB family members in these studies, but an in-frame tandem duplication of exons 18-25/18-26 of the EGFR was found, that comprise the tyrosine kinase domain and the whole or part of the CAIN domain, where the CLBS is located, resulting in 190/185 kDa mutant receptors with two CLBSs [175, 176], as was previously reported in different glioma cell lines [177, 178]. The CLBS of the EGFR includes Tyr992 at its C-terminal end, which upon phosphorylation recruits and activates PLC $\gamma$ [179], leading to $\mathrm{Ca}^{2+}$ release from the ER. Deletion of the CAIN domain, and hence the lack of the CLBS, or mutation of its acidic residues or Tyr992, increases the transforming activity of the EGFR and of the N-terminal truncated c-erbB homologue encoded by the avian erythroleukemia virus, suggesting that this region plays a role in decreasing their transformation potential [180].

ErbB2 was also demonstrated to be $\mathrm{Ca}^{2+} / \mathrm{CaM}$-binding protein, with a CBS located in the cytosolic juxtamembrane region [181], as in the case of the EGFR (Table 4). More recently, White et al. identified two CBS in ErbB2 [182]. Similar juxtamembrane CBSs where identified in ErbB4 and ErbB3, although the latter receptor has lower homology to the one identified in EGFR [169]. Consistent with this, the CBS of ErbB3 has a lower affinity $\left(K_{a}=3 \mu \mathrm{M}\right)$ for $\mathrm{Ca}^{2+} / \mathrm{CaM}$, as compared to the other three receptors, with $K_{a}$ values of $10 \mathrm{nM}$ in EGFR, $0.2 \mu \mathrm{M}$ in ErbB4, and $0.6 \mu \mathrm{M}$ in ErbB2 [183]. Of notice, the lower affinity of ErbB3 for $\mathrm{Ca}^{2+} / \mathrm{CaM}$ correlates with the absence of intrinsic tyrosine kinase activity of this receptor, which only forms active heterodimers with other family members such as ErbB2, which lacks of ligand-binding capacity [184]. This underscores the importance of CaM in ErbB receptors activation. Likewise,
CLBSs were also identified in ErbB2, ErbB3 and ErbB4, similar to the one in EGFR (Table 4), and once again the one in ErbB3 has the lowest similarity to EGFR, as compare to the other two receptors [169].

\section{Transport systems}

The CaM-dependent plasma membrane $\mathrm{Ca}^{2+}$-ATPase (PMCA) is one of the major $\mathrm{Ca}^{2+}$-transport systems maintaining cytosolic $\mathrm{Ca}^{2+}$ at low concentration by extruding this cation to the extracellular fluid. It has ten transmembrane segments and a bulky cytosolic region where the catalytic site resides formed by two major and two minor loops and a C-terminal tail (Figs. 1, 6a, b). Two acidic regions in the first and second intracellular loops denoted the CLBS have an important function in regulating the enzyme, as it induces auto-inhibition in the absence of $\mathrm{Ca}^{2+} / \mathrm{CaM}$ likely by blocking CaM binding to the CBS of the pump [185, 186] (Fig. 6b). Removal of the CaM-BD by proteolytic digestion with trypsin [187-189], or the endogenous $\mathrm{Ca}^{2+}$-dependent protease calpain $[78,79,133]$, prevents its interaction with the auto-inhibitory CLBS and results in a CaM-independent constitutively active $\mathrm{Ca}^{2+}$-ATPase (reviewed in $[80,190]$ ). This underscores the interaction of the CBS with the autoinhibitory region of the enzyme.

The formation of a complex between $\mathrm{CaM}$ and a regulatory region in NHE1, an important $\mathrm{pH}$, salt concentration and volume regulator, has been shown to occur by structural analysis, facilitating our understanding of the role of $\mathrm{Ca}^{2+} / \mathrm{CaM}$ in its activation [191] (Fig. 7a, b). This report shows that the C-terminal tail of this transporter contains two nearby CBSs located at amino acid residues 629-652 (proximal) and 658-671 (distal), respectively. It has been proposed that in resting cells, when the cytosolic concentration of $\mathrm{Ca}^{2+}$ is very low, the distal CBS interacts with the so-called proton modifier site (PMS), located in the C-terminal end of an intramembrane loop, inducing autoinhibition [191, 192]. Moreover, it has been hypothesized that the proximal CBS also interacts electrostatically with a highly acidic cluster (amino acid residues 753-759) distal of the CBSs [191, 193]. This region may have the functional characteristics of a non-EF-hand CLBS described above and has been proposed to be involved in maintaining an adequate conformation of the cytosolic domain, promoting CaM binding and activation of the exchanger [191-193]. When the cytosolic $\mathrm{Ca}^{2+}$ concentration increases, $\mathrm{Ca}^{2+} / \mathrm{CaM}$ binds with the N-lobe to distal CBS and with the C-lobe to proximal CBS [191] and this releases the autoinhibitory/distal CBS from the PMS leading to activation of the exchanger, at the same time that the CLBS is detached from the CBSs. Figure $7 \mathrm{~b}$ depicts a model illustrating this concept. 
A

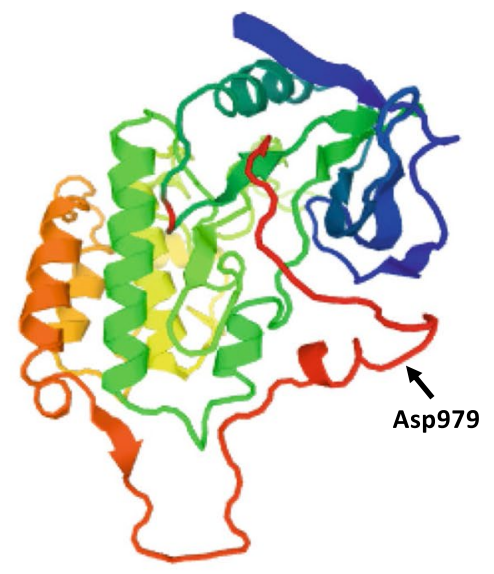

EGFR $_{\text {cyt }}$

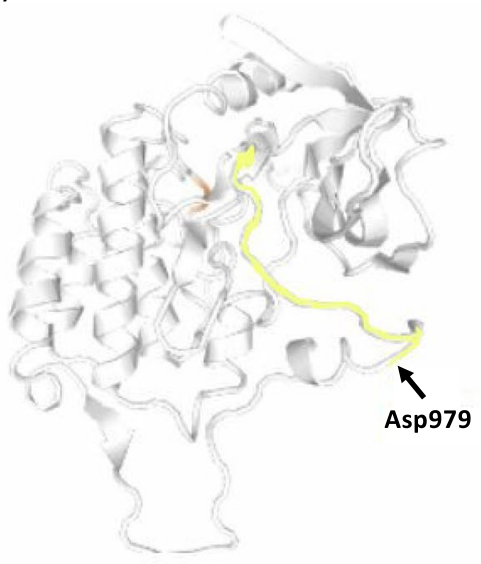

B

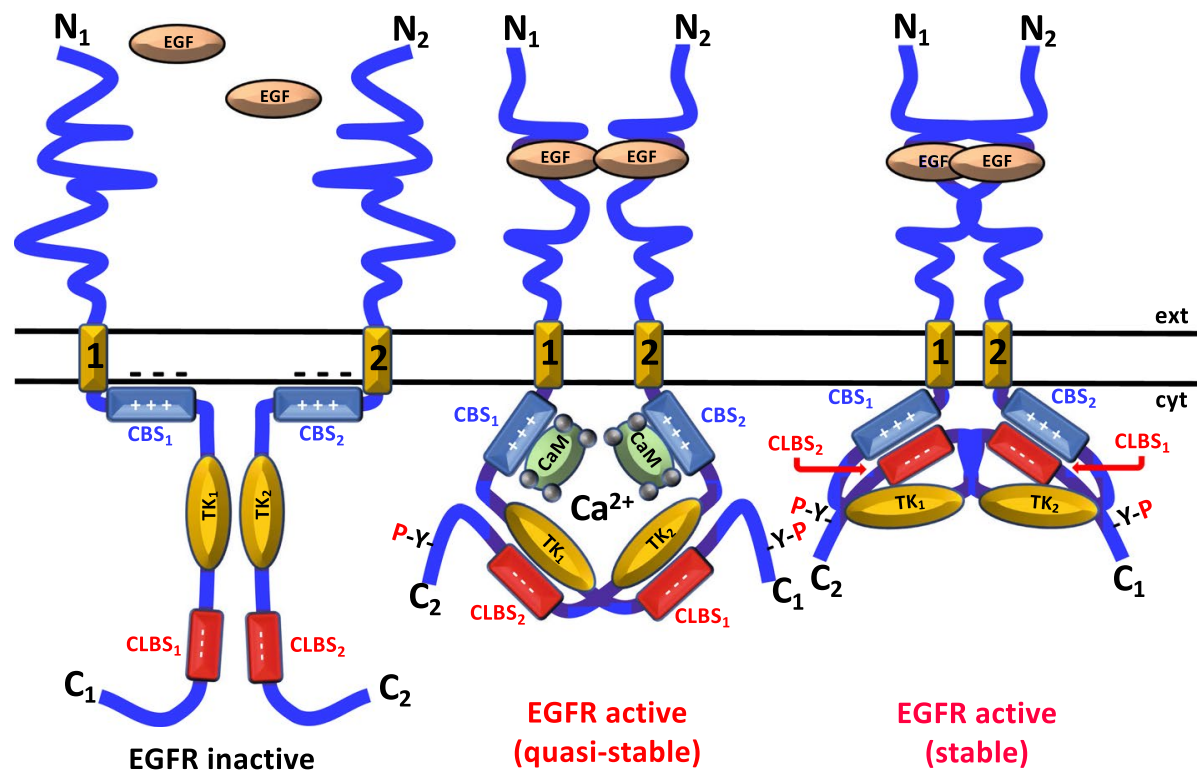

Fig. 5 Structure and functional role of CBS/CLBS interaction in the EGFR. a The figure depicts the X-ray crystallographic structure of the cytosolic region of the human epidermal growth factor receptor $\left(\mathrm{EGFR}_{\text {cyt }}\right)$ at $3.2 \AA$ resolution (P00533 EGFR_HUMAN based on template $3 \mathrm{rcdA}$, residue range $702-1015$ corresponding to residues 678-991 in the mature receptor lacking the 24 amino acids of the signal peptide) taken and modified from UniProt MODBASE database using a rainbow color code (left panel) going from the N-terminal (blue) to the C-terminal (red), and the location of the CaM-like domain (CLBS) highlights in color starting at Asp979 (right panel). b At resting basal conditions (left panel), the monomeric ligand-free epidermal growth factor receptor (EGFR) has the positively charged juxtamembrane calmodulin-binding domain (CBS) (blue segment) electrostatically bound to the negatively charged inner leaflet of the plasma membrane (minus symbols), which is rich in acidic phosphoinositides, maintaining the receptor in an auto-inhibited state [183]. Upon binding of the ligand epidermal growth factor (EGF) (cen- tral panel), the receptor initiates its dimerization and the $\mathrm{Ca}^{2+} / \mathrm{CaM}$ complex binds to the CBS helping to its detachment from the inner leaflet of the plasma membrane [183], and therefore contributing to the ligand-induced EGFR activation by trans-phosphorylation of C-terminal tyrosine residues $(-Y-P)$. In this model, we propose that the EGFR dimer is active but in a quasi-stable conformation. Subsequently, the active EGFR dimer releases the $\mathrm{Ca}^{2+} / \mathrm{CaM}$ complex and adopts a more stable conformation (right panel) by the electrostatic interaction between of positively charged CBS (blue segment) of one EGFR monomer (labeled 1) with the negatively charged CaMlike domain (CLBS) (red segment) of the apposed EGFR monomer (labeled 2). For clarity, the N- and C-termini, transmembrane region (yellow segment), CBS, CLBS, and tyrosine kinase domain (TK) of each EGFR monomer are labeled with numbers 1 and 2 to document CBS/CLBS hetero-interaction of apposed monomers. $\mathrm{Ca}^{2+}$ ions are represented by gray spheres. ext extracellular medium, cyt cytosol. Adapted from Ref. [173] 
A

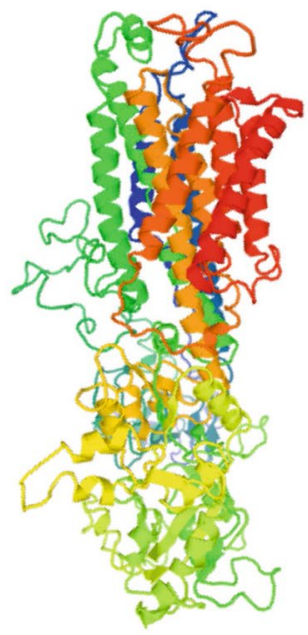

PMCA1

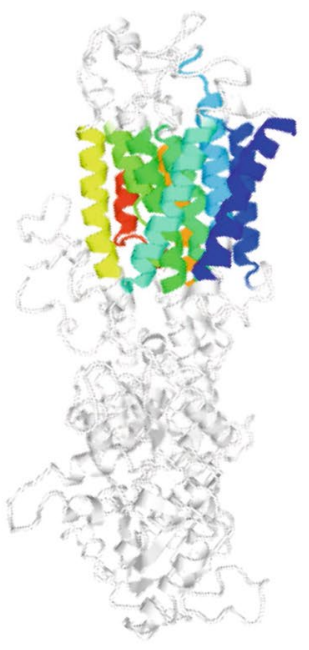

B

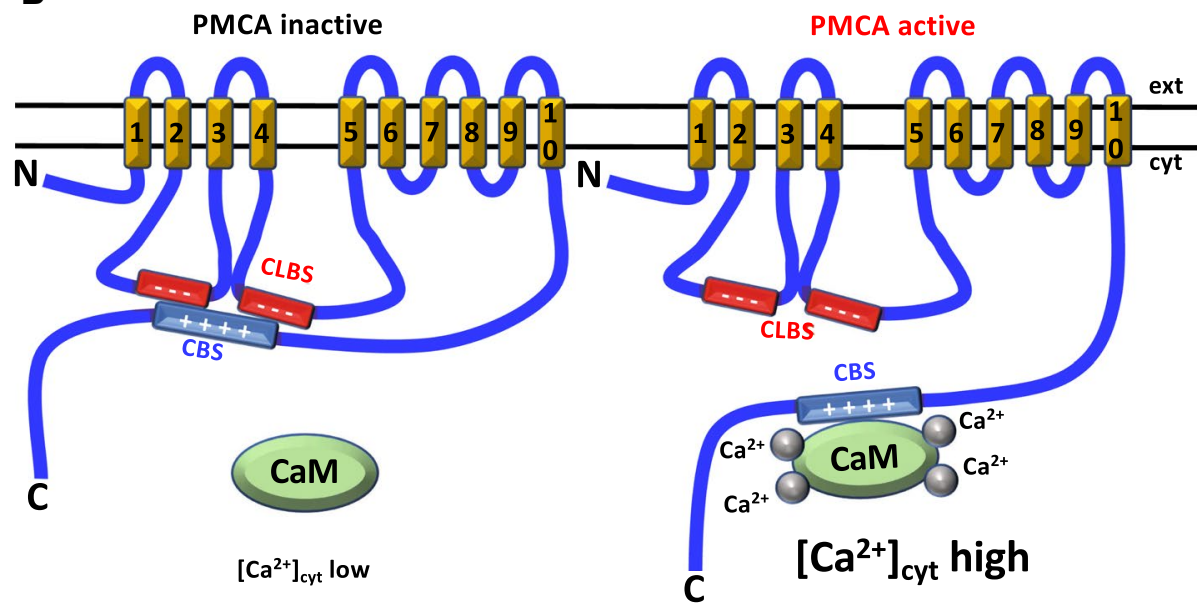

Fig. 6 Structure and functional role of CBS/CLBS interaction in the plasma membrane $\mathrm{Ca}^{2+}$-ATPase. a The figure depicts the X-ray crystallographic structure of human plasma membrane $\mathrm{Ca}^{2+}$-ATPase isoform 1 (PMCA1) at $3 \AA$ resolution (P20020 AT2B1_HUMAN based on template $2 \mathrm{c} 9 \mathrm{~mA}$, residue range 52-1063) taken from UniProt SWISS-MODEL database. The crystallographic structure in the left panel is shown using a rainbow color code going from the $\mathrm{N}$-terminal (blue) to the C-terminal (red), and in the right panel highlights in different colors the ten transmembrane segments. b At low cytosolic $\mathrm{Ca}^{2+}$ concentration the positively charged CaM-binding site (CBS) (blue segment), located at the C-terminal tail of the enzyme, is free of calmodulin $(\mathrm{CaM})$ and interacts with two acidic regions representing a bi-partite calmodulin-like binding site (CLBS) (red segments), respectively located in the first and second intracellular bulky

\section{The potential role of decoy proteins on calmodulin-binding proteins}

In addition to the occurrence of CLBS in CaM-binding proteins, in which CBS/CLBS interaction is expected [20], as we have discussed in "Calmodulin-binding proteins with non-EF-hand CaM-like binding sites (CLBSs)", an loops of the enzyme. The first loop goes between the second and third transmembrane region, and the second loop goes between the fourth and fifth transmembrane region (yellow segments). The CBS has two interaction sites separated by a 38 amino acids segment (not shown). The ten transmembrane regions are numbered, and the N- and C-termini of the enzyme indicated. The interaction of the CBS with the CLBS maintains the enzyme in an auto-inhibited state (left panel). When the cytosolic $\mathrm{Ca}^{2+}$ concentration increases the $\mathrm{Ca}^{2+} / \mathrm{CaM}$ complex is formed, binding with high affinity to the CBS and detaching itself from the CLBS, which renders the enzyme active (right panel). $\mathrm{Ca}^{2+}$ ions are represented by gray spheres. ext extracellular medium, cyt cytosol, PMCA plasma membrane $\mathrm{Ca}^{2+}$-ATPase. Adapted from Ref. [217]

intriguing emerging possibility is the binding of the CLBS of CaM-binding proteins to decoy proteins behaving as $\mathrm{CaM}$ but exerting a different functional role. This appears to be the case for the apoptosis-inducing protein Bak, as this endoplasmic reticulum (ER)-associated protein is able to interact with both the kinase domain and the CBS of DAPK1, facilitating the entry of ER-Ca ${ }^{2+}$ into the mitochondria [194]. 

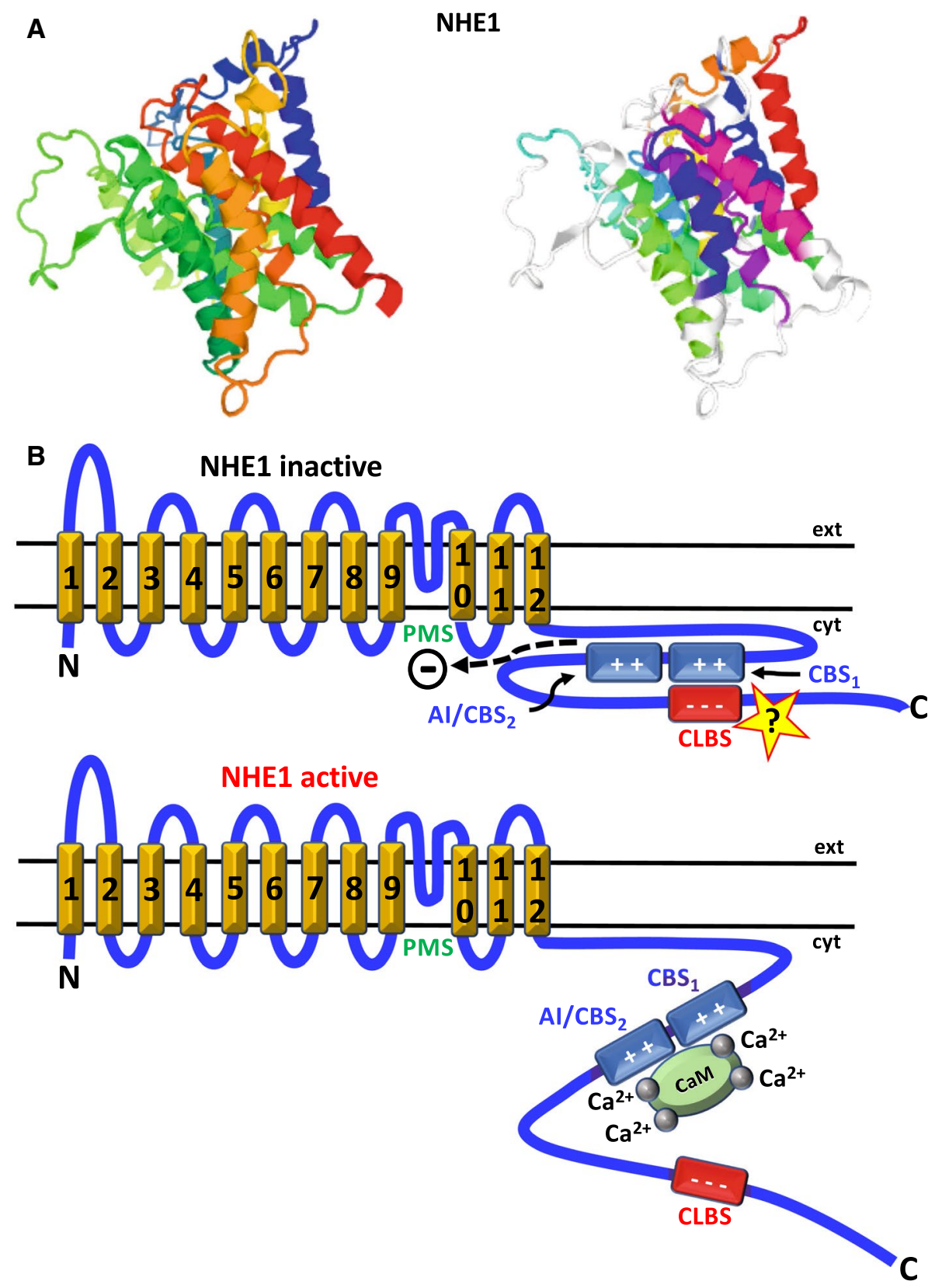

Fig. 7 Structure and functional role of CBS/CLBS interaction in the $\mathrm{Na}^{+} / \mathrm{H}^{+}$-exchanger. a The figure depicts the X-ray crystallographic structure of rat $\mathrm{Na}^{+} / \mathrm{H}^{+}$-exchanger 1 (NHE1) at $3.5 \AA$ resolution (P26431 SL9A1_RAT based on template 1zcda, residue range 109-510) taken from UniProt MODBASE database using a rainbow color code (left panel) going from the N-terminal (blue) to the C-terminal (red), and the location of eleven transmembrane and one intramembrane segment highlighted in different colors (right panel). b In resting conditions, the $\mathrm{Na}^{+} / \mathrm{H}^{+}$-exchanger 1 (NHE1) remains auto-inhibited (top panel) as the distal autoinhibitory/calmodulinbinding site $\left(\mathrm{AI} / \mathrm{CBS}_{2}\right)$ has autoinhibitory function interacting with the proton modifier site (PMS) (dashed arrow), located in an intram-

This suggests the existence of at least one non-canonical CLBS in Bak. The search for interaction of CaM-binding proteins with proteins having CLBS, and the study of their embrane loop region. It has been hypothesized that $\mathrm{CBS}_{1}$ (proximal CBS) interacts electrostatically with the distal-located negatively charged CaM-like site (CLBS) (marked with a question mark). When the cytosolic $\mathrm{Ca}^{2+}$ concentration increases the $\mathrm{Ca}^{2+} / \mathrm{CaM}$ complex is formed, binding to both the proximal and distal CBSs $\left(\mathrm{CBS}_{1}\right.$ and $\mathrm{CBS}_{2}$, respectively) the autoinhibition is released by detachment of $\mathrm{AI} / \mathrm{CBS}_{2}$ from the regulatory PMS, rendering the NHE1 active (bottom panel). $\mathrm{Ca}^{2+}$ ions are represented by gray spheres. ext extracellular medium, cyt cytosol. The twelve transmembrane segments (yellow) are numbered, and the $\mathrm{N}$ - and $\mathrm{C}$-termini of the exchanger are indicated. Adapted from references [191-193]

functional roles, would be of interest to investigate. We suggest that a potential role of this type of CBS/CLBS interaction could be to regulate the action of $\mathrm{CaM}$ on the target 
proteins. In addition, myristoylated $\mathrm{Ca}^{2+}$-binding proteins that participate in diverse physiological functions exhibit great sequence similarity to CaN-B [195-197]. Like the $\mathrm{CaM}$-like proteins, many $\mathrm{CaN}-\mathrm{B}$-like proteins are expressed in a great variety of plants (reviewed in [198]). However, the function of these proteins appears to be unrelated to $\mathrm{CaN}-\mathrm{A}$ regulation, participating instead in membrane trafficking, microtubule transport activity or interacting with the platelet fibrinogen receptor. Nevertheless, the possibility that myristoylated $\mathrm{Ca}^{2+}$-binding proteins could act as decoys to block the action of CaN-B on CaN-A is a possibility that warrant further investigation.

\section{Perspectives}

A large number of ion channels bind and are regulated by $\mathrm{CaM}$, either in its $\mathrm{Ca}^{2+}$-bound and/or $\mathrm{Ca}^{2+}$-free form. This includes the $\mathrm{IP}_{3}$ and ryanodine receptors (reviewed in [199, 200]), ORAI channels (reviewed in [201]), TRP channels (reviewed in [202, 203]), ligand-gated $\mathrm{Ca}^{2+}$ channels (reviewed in [204]), voltage-dependent $\mathrm{Ca}^{2+}$ channels (reviewed in [205]), voltage-dependent $\mathrm{Na}^{+}$channels (reviewed in [206, 207]), voltage-dependent $\mathrm{K}^{+}$channels [208, 209], $\mathrm{Ca}^{2+}$-activated $\mathrm{K}^{+}$channels (reviewed in [210]), and $\mathrm{Ca}^{2+}$-activated $\mathrm{Cl}^{-}$channels (reviewed in [211]). Although in certain cases $\mathrm{CaM}$ is constitutively bound to some ion channels and can be considered an intrinsic subunit of the channel [19], it is important to consider whether the CBS of these channels, when free of CaM, could interact with other regions of the same or different subunit of the channel. If so, these regions could be considered CLBSs. However, to our knowledge no information about the existence of these potential CLBSs within ion channels is available. This could be an interesting topic of future research, as its study may underscore the functionality of these potential regulatory regions. As mentioned in the different sections, the interaction between the CBS and its CLBS has only been established with certainty in a few non-EF-hand proteins discussed in this review. Therefore, effort for further investigations in this area of research should be of interest, as this could give additional information on the functional roles of these domains.

Acknowledgements Original work in the authors laboratories were funded by the Secretaría de Estado de Investigación, Desarrollo e Innovación Grant SAF2014-52048-R, and the Consejería de Educación, Juventud y Deportes-Comunidad de Madrid Grant B2017/ BMD-36 involving contributions from the European Funds for Regional Development (EFRD) and the Social European Fund (SEF) (to AV); the Danish Research Council Grant DFF-4004-00560, the AP Møller Foundation, Dagmar Marshalls Foundation, Einar Willumsen Foundation, Aase and Ejnar Danielsen Foundation, Wedell Wedellsborg Foundation, Frænkels Foundation and the Danish Heart Foundation Grant 13-04-R94-A4547-2280 (to MWB).

\section{References}

1. Kretsinger RH (1975) Hypothesis: calcium modulated proteins contain EF hands. In: Carafoli E, Clementi F, Drabikowski W, Margreth A (eds) Calcium transport in contraction and secretion. Elsevier, Amsterdam, pp 469-478 (ISBN: 044410917X )

2. Berchtold MW (1993) Evolution of EF-hand calcium-modulated proteins. V. The genes encoding EF-hand proteins are not clustered in mammalian genomes. J Mol Evol 36:489-496

3. Kawasaki H, Nakayama S, Kretsinger RH (1998) Classification and evolution of EF-hand proteins. Biometals 11:277-295

4. Kawasaki H, Kretsinger RH (2017) Structural and functional diversity of EF-hand proteins: evolutionary perspectives. Protein Sci 26:1898-1920

5. Villalobo A, Ishida H, Vogel HJ, Berchtold MW (2018) Calmodulin as a protein linker and a regulator of adaptor/scaffold proteins. Biochim Biophys Acta 1865:507-521

6. Klee CB, Vanaman TC (1982) Calmodulin. Adv Protein Chem $35: 213-321$

7. Chin D, Means AR (2000) Calmodulin: a prototypical calcium sensor. Trends Cell Biol 10:322-328

8. Benaim G, Villalobo A (2002) Phosphorylation of calmodulin. Functional implications. Eur J Biochem 269:3619-3631

9. Berchtold MW, Villalobo A (2014) The many faces of calmodulin in cell proliferation, programmed cell death, autophagy, and cancer. Biochim Biophys Acta 1843:398-435

10. Villarroel A, Taglialatela M, Bernardo-Seisdedos G, Alaimo A, Agirre J, Alberdi A, Gomis-Perez C, Soldovieri MV, Ambrosino P, Malo C, Areso P (2014) The ever changing moods of calmodulin: how structural plasticity entails transductional adaptability. J Mol Biol 426:2717-2735

11. Jurado LA, Chockalingam PS, Jarrett HW (1999) Apocalmodulin. Physiol Rev 79:661-682

12. Bähler M, Rhoads A (2002) Calmodulin signaling via the IQ motif. FEBS Lett 513:107-113

13. Berchtold MW, Egli R, Rhyner JA, Hameister H, Strehler EE (1993) Localization of the human bona fide calmodulin genes CALM1, CALM2, and CALM3 to chromosomes 14q24-q31, 2p21.1-p21.3, and 19q13.2-q13.3. Genomics 16:461-465

14. Putkey JA, Ts'ui KF, Tanaka T, Lagace L, Stein JP, Lai EC, Means AR (1983) Chicken calmodulin genes. A species comparison of cDNA sequences and isolation of a genomic clone. $\mathrm{J}$ Biol Chem 258:11864-11870

15. Perochon A, Aldon D, Galaud JP, Ranty B (2011) Calmodulin and calmodulin-like proteins in plant calcium signaling. Biochimie 93:2048-2053

16. Zeng H, Xu L, Singh A, Wang H, Du L, Poovaiah BW (2015) Involvement of calmodulin and calmodulin-like proteins in plant responses to abiotic stresses. Front Plant Sci 6:600

17. Brushia RJ, Walsh DA (1999) Phosphorylase kinase: the complexity of its regulation is reflected in the complexity of its structure. Front Biosci 4:D618-D641

18. Marletta MA (1994) Nitric oxide synthase: aspects concerning structure and catalysis. Cell 78:927-930

19. Saimi Y, Kung C (2002) Calmodulin as an ion channel subunit. Annu Rev Physiol 64:289-311

20. Jarrett HW, Madhavan R (1991) Calmodulin-binding proteins also have a calmodulin-like binding site within their structure. The flip-flop model. J Biol Chem 266:362-371

21. Ohno S, Emori Y, Imajoh S, Kawasaki H, Kisaragi M, Suzuki K (1984) Evolutionary origin of a calcium-dependent protease by fusion of genes for a thiol protease and a calcium-binding protein? Nature 312:566-570 
22. Zhang XS, Choi JH (2001) Molecular evolution of calmodulinlike domain protein kinases (CDPKs) in plants and protists. J Mol Evol 53:214-224

23. Chen F, Zhang L, Cheng ZM (2017) The calmodulin fused kinase novel gene family is the major system in plants converting $\mathrm{Ca}^{2+}$ signals to protein phosphorylation responses. Sci Rep 7:4127

24. Breviario D, Morello L, Giani S (1995) Molecular cloning of two novel rice cDNA sequences encoding putative calciumdependent protein kinases. Plant Mol Biol 27:953-967

25. Roberts DM (1992) Calcium-modulated proteins: targets of intracellular calcium signals in higher plants. Annu Rev Plant Physiol Plant Mol Biol 43:375-414

26. Roberts DM (1993) Protein kinases with calmodulin-like domains: novel targets of calcium signals in plants. Curr Opin Cell Biol 5:242-246

27. Harper JF, Huang JF, Lloyd SJ (1994) Genetic identification of an autoinhibitor in CDPK, a protein kinase with a calmodulin-like domain. Biochemistry 33:7267-7277

28. Harmon AC, Yoo BC, McCaffery C (1994) Pseudosubstrate inhibition of CDPK, a protein kinase with a calmodulin-like domain. Biochemistry 33:7278-7287

29. Weljie AM, Clarke TE, Juffer AH, Harmon AC, Vogel HJ (2000) Comparative modeling studies of the calmodulin-like domain of calcium-dependent protein kinase from soybean. Proteins 39:343-357

30. Christodoulou J, Malmendal A, Harper JF, Chazin WJ (2004) Evidence for differing roles for each lobe of the calmodulinlike domain in a calcium-dependent protein kinase. J Biol Chem 279:29092-29100

31. Liese A, Romeis T (2013) Biochemical regulation of in vivo function of plant calcium-dependent protein kinases (CDPK). Biochim Biophys Acta 1833:1582-1589

32. Chandran V, Stollar EJ, Lindorff-Larsen K, Harper JF, Chazin WJ, Dobson CM, Luisi BF, Christodoulou J (2006) Structure of the regulatory apparatus of a calcium-dependent protein kinase (CDPK): a novel mode of calmodulin-target recognition. J Mol Biol 357:400-410

33. Yoo BC, Harmon AC (1996) Intramolecular binding contributes to the activation of CDPK, a protein kinase with a calmodulinlike domain. Biochemistry 35:12029-12037

34. Huang JF, Teyton L, Harper JF (1996) Activation of a $\mathrm{Ca}^{2+}$-dependent protein kinase involves intramolecular binding of a calmodulin-like regulatory domain. Biochemistry 35:13222-13230

35. Vitart V, Christodoulou J, Huang JF, Chazin WJ, Harper JF (2000) Intramolecular activation of a $\mathrm{Ca}^{2+}$-dependent protein kinase is disrupted by insertions in the tether that connects the calmodulin-like domain to the kinase (correction in Biochemistry 39: 12102, 2000). Biochemistry 39:4004-4011

36. Hegeman AD, Rodriguez M, Han BW, Uno Y, Phillips GN Jr, Hrabak EM, Cushman JC, Harper JF, Harmon AC, Sussman MR (2006) A phyloproteomic characterization of in vitro autophosphorylation in calcium-dependent protein kinases. Proteomics 6:3649-3664

37. Harper JF, Sussman MR, Schaller GE, Putnam-Evans C, Charbonneau H, Harmon AC (1991) A calcium-dependent protein kinase with a regulatory domain similar to calmodulin. Science 252:951-954

38. Lee JY, Yoo BC, Harmon AC (1998) Kinetic and calcium-binding properties of three calcium-dependent protein kinase isoenzymes from soybean. Biochemistry 37:6801-6809

39. Bender KW, Blackburn RK, Monaghan J, Derbyshire P, Menke FL, Zipfel C, Goshe MB, Zielinski RE, Huber SC (2017) Autophosphorylation-based calcium $\left(\mathrm{Ca}^{2+}\right)$ sensitivity priming and $\mathrm{Ca}^{2+} /$ calmodulin inhibition of Arabidopsis thaliana $\mathrm{Ca}^{2+}$-dependent protein kinase 28 (CPK28). J Biol Chem 292:3988-4002

40. Mittal S, Mallikarjuna MG, Rao AR, Jain PA, Dash PK, Thirunavukkarasu N (2017) Comparative analysis of CDPK family in maize, arabidopsis, rice, and sorghum revealed potential targets for drought tolerance improvement. Front Chem 5:115

41. Weljie AM, Gagne SM, Vogel HJ (2004) Solution structure and backbone dynamics of the $\mathrm{N}$-terminal region of the calcium regulatory domain from soybean calcium-dependent protein kinase $\alpha$. Biochemistry 43:15131-15140

42. Weljie AM, Vogel HJ (2004) Unexpected structure of the $\mathrm{Ca}^{2+}$-regulatory region from soybean calcium-dependent protein kinase- $\alpha$. J Biol Chem 279:35494-35502

43. Weljie AM, Robertson KM, Vogel HJ (2003) Conformational changes in the $\mathrm{Ca}^{2+}$-regulatory region from soybean calciumdependent protein kinase- $\alpha$ : fluorescence resonance energy transfer studies. J Biol Chem 278:43764-43769

44. Chaudhuri S, Seal A, Gupta MD (1999) Autophosphorylationdependent activation of a calcium-dependent protein kinase from groundnut. Plant Physiol 120:859-866

45. Vivek PJ, Tuteja N, Soniya EV (2013) CDPK1 from ginger promotes salinity and drought stress tolerance without yield penalty by improving growth and photosynthesis in Nicotiana tabacum. PLoS One 8:e76392

46. Raichaudhuri A, Bhattacharyya R, Chaudhuri S, Chakrabarti P, Dasgupta M (2006) Domain analysis of a groundnut calciumdependent protein kinase: nuclear localization sequence in the junction domain is coupled with nonconsensus calcium binding domains. J Biol Chem 281:10399-10409

47. Oh MH, Wu X, Kim HS, Harper JF, Zielinski RE, Clouse SD, Huber SC (2012) CDPKs are dual-specificity protein kinases and tyrosine autophosphorylation attenuates kinase activity. FEBS Lett 586:4070-4075

48. Saha P, Singh M (1995) Characterization of a winged bean (Psophocarpus tetragonolobus) protein kinase with calmodulin-like domain: regulation by autophosphorylation. Biochem $\mathrm{J}$ 305(Pt 1):205-210

49. Romeis T, Herde M (2014) From local to global: CDPKs in systemic defense signaling upon microbial and herbivore attack. Curr Opin Plant Biol 20:1-10

50. Guo YL, Roux SJ (1990) Partial purification and characterization of a $\mathrm{Ca}^{2+}$-dependent protein kinase from the green alga, Dunaliella salina. Plant Physiol 94:143-150

51. Siderius M, Henskens H, Porto-leBlanche A, van Himbergen J, Musgrave A, Haring M (1997) Characterisation and cloning of a calmodulin-like domain protein kinase from Chlamydomonas moewusii (Gerloff). Planta 202:76-84

52. Bender KW, Zielinski RE, Huber SC (2018) Revisiting paradigms of $\mathrm{Ca}^{2+}$ signaling protein kinase regulation in plants. Biochem J 475:207-223

53. Kadian K, Gupta Y, Kempaiah P, Gupta N, Sharma A, Rawat M (2017) Calcium dependent protein kinases (CDPKs): key to malaria eradication. Curr Top Med Chem 17:2215-2220

54. Andresen C, Niklasson M, Cassman Eklof S, Wallner B, Lundstrom P (2017) Biophysical characterization of the calmodulinlike domain of Plasmodium falciparum calcium dependent protein kinase 3. PLoS One 12:e0181721

55. Ranjan R, Ahmed A, Gourinath S, Sharma P (2009) Dissection of mechanisms involved in the regulation of Plasmodium falciparum calcium-dependent protein kinase 4. J Biol Chem 284:15267-15276

56. Donald RG, Zhong T, Wiersma H, Nare B, Yao D, Lee A, Allocco J, Liberator PA (2006) Anticoccidial kinase inhibitors: identification of protein kinase targets secondary to cGMPdependent protein kinase. Mol Biochem Parasitol 149:86-98 
57. Van Voorhis WC, Doggett JS, Parsons M, Hulverson MA, Choi R, Arnold SLM, Riggs MW, Hemphill A, Howe DK, Mealey RH, Lau AOT, Merritt EA, Maly DJ, Fan E, Ojo KK (2017) Extended-spectrum antiprotozoal bumped kinase inhibitors: a review. Exp Parasitol 180:71-83

58. Sugi T, Kobayashi K, Takemae H, Gong H, Ishiwa A, Murakoshi F, Recuenco FC, Iwanaga T, Horimoto T, Akashi H, Kato K (2013) Identification of mutations in TgMAPK1 of Toxoplasma gondii conferring resistance to 1NM-PP1. Int J Parasitol Drugs Drug Resist 3:93-101

59. Foroutan M, Ghaffarifar F (2018) Calcium-dependent protein kinases are potential targets for Toxoplasma gondii vaccine. Clin Exp Vaccine Res 7:24-36

60. Dunn PP, Bumstead JM, Tomley FM (1996) Sequence, expression and localization of calmodulin-domain protein kinases in Eimeria tenella and Eimeria maxima. Parasitology 113(Pt 5):439-448

61. Murachi T (1984) Calcium-dependent proteinases and specific inhibitors: calpain and calpastatin. Biochem Soc Symp 49:149-167

62. Goll DE, Thompson VF, Li H, Wei W, Cong J (2003) The calpain system. Physiol Rev 83:731-801

63. Ono Y, Ojima K, Shinkai-Ouchi F, Hata S, Sorimachi H (2016) An eccentric calpain, CAPN3/p94/calpain-3. Biochimie 122:169-187

64. Storr SJ, Carragher NO, Frame MC, Parr T, Martin SG (2011) The calpain system and cancer. Nat Rev Cancer 11:364-374

65. Waghray A, Wang DS, McKinsey D, Hayes RL, Wang KK (2004) Molecular cloning and characterization of rat and human calpain-5. Biochem Biophys Res Commun 324:46-51

66. Strobl S, Fernandez-Catalan C, Braun M, Huber R, Masumoto H, Nakagawa K, Irie A, Sorimachi H, Bourenkow G, Bartunik H, Suzuki K, Bode W (2000) The crystal structure of calcium-free human m-calpain suggests an electrostatic switch mechanism for activation by calcium. Proc Natl Acad Sci USA 97:588-592

67. Hosfield CM, Elce JS, Davies PL, Jia Z (1999) Crystal structure of calpain reveals the structural basis for $\mathrm{Ca}^{2+}$-dependent protease activity and a novel mode of enzyme activation. EMBO J 18:6880-6889

68. Suzuki K, Hata S, Kawabata Y, Sorimachi H (2004) Structure, activation, and biology of calpain. Diabetes 53(Suppl 1):S12-S18

69. Vilei EM, Calderara S, Anagli J, Berardi S, Hitomi K, Maki M, Carafoli E (1997) Functional properties of recombinant calpain I and of mutants lacking domains III and IV of the catalytic subunit. J Biol Chem 272:25802-25808

70. Goll DE, Thompson VF, Taylor RG, Zalewska T (1992) Is calpain activity regulated by membranes and autolysis or by calcium and calpastatin? BioEssays 14:549-556

71. Friedrich $\mathrm{P}$ (2004) The intriguing $\mathrm{Ca}^{2+}$ requirement of calpain activation. Biochem Biophys Res Commun 323:1131-1133

72. Dutt P, Spriggs CN, Davies PL, Jia Z, Elce JS (2002) Origins of the difference in $\mathrm{Ca}^{2+}$ requirement for activation of $\mu$ - and m-calpain. Biochem J 367:263-269

73. Molinari M, Maki M, Carafoli E (1995) Purification of $\mu$-calpain by a novel affinity chromatography approach. New insights into the mechanism of the interaction of the protease with targets. $\mathrm{J}$ Biol Chem 270:14576-14581

74. Reverter D, Strobl S, Fernandez-Catalan C, Sorimachi H, Suzuki K, Bode W (2001) Structural basis for possible calcium-induced activation mechanisms of calpains. Biol Chem 382:753-766

75. Theopold U, Pinter M, Daffre S, Tryselius Y, Friedrich P, Nassel DR, Hultmark D (1995) CalpA, a Drosophila calpain homolog specifically expressed in a small set of nerve, midgut, and blood cells. Mol Cell Biol 15:824-834
76. Hong H, Johnson P, El-Saleh SC (1990) Effects of calcium and calmodulin antagonists on calpain II subunit conformations. Int J Biol Macromol 12:269-272

77. Suo S, Koike H, Sorimachi H, Ishiura S, Suzuki K (1999) Association and dissociation of the calcium-binding domains of calpain by $\mathrm{Ca}^{2+}$. Biochem Biophys Res Commun 257:63-66

78. Wang KK, Villalobo A, Roufogalis BD (1988) Activation of the $\mathrm{Ca}^{2+}$-ATPase of human erythrocyte membrane by an endogenous $\mathrm{Ca}^{2+}$-dependent neutral protease. Arch Biochem Biophys 260:696-704

79. Wang KK, Roufogalis BD, Villalobo A (1988) Further characterization of calpain-mediated proteolysis of the human erythrocyte plasma membrane $\mathrm{Ca}^{2+}$-ATPase. Arch Biochem Biophys 267:317-327

80. Wang KK, Villalobo A, Roufogalis BD (1989) Calmodulinbinding proteins as calpain substrates. Biochem J 262:693-706

81. Shumway SD, Maki M, Miyamoto S (1999) The PEST domain of $\mathrm{I} \kappa \mathrm{B} \alpha$ is necessary and sufficient for in vitro degradation by $\mu$-calpain. J Biol Chem 274:30874-30881

82. Croall DE, Chacko S, Wang Z (1996) Cleavage of caldesmon and calponin by calpain: substrate recognition is not dependent on calmodulin binding domains. Biochim Biophys Acta 1298:276-284

83. Yang HQ, Ma H, Takano E, Hatanaka M, Maki M (1994) Analysis of calcium-dependent interaction between aminoterminal conserved region of calpastatin functional domain and calmodulin-like domain of $\mu$-calpain large subunit. J Biol Chem 269:18977-18984

84. Takano E, Ma H, Yang HQ, Maki M, Hatanaka M (1995) Preference of calcium-dependent interactions between calmodulinlike domains of calpain and calpastatin subdomains. FEBS Lett 362:93-97

85. Ma H, Yang HQ, Takano E, Hatanaka M, Maki M (1994) Aminoterminal conserved region in proteinase inhibitor domain of calpastatin potentiates its calpain inhibitory activity by interacting with calmodulin-like domain of the proteinase. J Biol Chem 269:24430-24436

86. Ma H, Yang HQ, Takano E, Lee WJ, Hatanaka M, Maki M (1993) Requirement of different subdomains of calpastatin for calpain inhibition and for binding to calmodulin-like domains. $\mathrm{J}$ Biochem 113:591-599

87. Deshmukh L, Wu L, Guttmann RP, Vinogradova O (2009) NMR structural characterization of the penta-peptide calpain inhibitor. FEBS Lett 583:135-140

88. MacDonald MJ, Brown LJ (1996) Calcium activation of mitochondrial glycerol phosphate dehydrogenase restudied. Arch Biochem Biophys 326:79-84

89. Brandes RP, Weissmann N, Schroder K (2014) Nox family NADPH oxidases: molecular mechanisms of activation. Free Radic Biol Med 76:208-226

90. Marino D, Dunand C, Puppo A, Pauly N (2012) A burst of plant NADPH oxidases. Trends Plant Sci 17:9-15

91. Banfi B, Tirone F, Durussel I, Knisz J, Moskwa P, Molnar GZ, Krause KH, Cox JA (2004) Mechanism of $\mathrm{Ca}^{2+}$ activation of the NADPH oxidase 5 (NOX5). J Biol Chem 279:18583-18591

92. Tirone F, Cox JA (2007) NADPH oxidase 5 (NOX5) interacts with and is regulated by calmodulin. FEBS Lett 581:1202-1208

93. Pandey D, Gratton JP, Rafikov R, Black SM, Fulton DJ (2011) Calcium/calmodulin-dependent kinase II mediates the phosphorylation and activation of NADPH oxidase 5. Mol Pharmacol 80:407-415

94. Torres MA, Onouchi H, Hamada S, Machida C, HammondKosack KE, Jones JD (1998) Six Arabidopsis thaliana homologues of the human respiratory burst oxidase (gp91phox). Plant J 14:365-370 
95. Ogasawara Y, Kaya H, Hiraoka G, Yumoto F, Kimura S, Kadota Y, Hishinuma H, Senzaki E, Yamagoe S, Nagata K, Nara M, Suzuki K, Tanokura M, Kuchitsu K (2008) Synergistic activation of the Arabidopsis NADPH oxidase AtrbohD by $\mathrm{Ca}^{2+}$ and phosphorylation. J Biol Chem 283:8885-8892

96. Takahashi S, Kimura S, Kaya H, lizuka A, Wong HL, Shimamoto K, Kuchitsu K (2012) Reactive oxygen species production and activation mechanism of the rice NADPH oxidase OsRbohB. J Biochem 152:37-43

97. Oda T, Hashimoto H, Kuwabara N, Akashi S, Hayashi K, Kojima C, Wong HL, Kawasaki T, Shimamoto K, Sato M, Shimizu T (2010) Structure of the N-terminal regulatory domain of a plant NADPH oxidase and its functional implications. J Biol Chem 285:1435-1445

98. Broderick MJ, Winder SJ (2005) Spectrin, $\alpha$-actinin, and dystrophin. Adv Protein Chem 70:203-246

99. Sjöblom B, Salmazo A, Djinovic-Carugo K (2008) $\alpha$-actinin structure and regulation. Cell Mol Life Sci 65:2688-2701

100. Travé G, Pastore A, Hyvonen M, Saraste M (1995) The C-terminal domain of $\alpha$-spectrin is structurally related to calmodulin. Eur J Biochem 227:35-42

101. Travers T, Shao H, Wells A, Camacho CJ (2013) Modeling the assembly of the multiple domains of $\alpha$-actinin- 4 and its role in actin cross-linking. Biophys J 104:705-715

102. Beggs AH, Byers TJ, Knoll JH, Boyce FM, Bruns GA, Kunkel LM (1992) Cloning and characterization of two human skeletal muscle $\alpha$-actinin genes located on chromosomes 1 and 11. J Biol Chem 267:9281-9288

103. Karlsson G, Persson C, Mayzel M, Hedenstrom M, Backman L (2016) Solution structure of the calmodulin-like C-terminal domain of Entamoeba $\alpha$-actinin2. Proteins 84:461-466

104. Drmota Prebil S, Slapsak U, Pavsic M, Ilc G, Puz V, de Almeida Ribeiro E, Anrather D, Hartl M, Backman L, Plavec J, Lenarcic B, Djinovic-Carugo K (2016) Structure and calcium-binding studies of calmodulin-like domain of human non-muscle $\alpha$-actinin-1. Sci Rep 6:27383

105. Shams H, Golji J, Garakani K, Mofrad MR (2016) Dynamic regulation of $\alpha$-actinin's calponin homology domains on F-actin. Biophys J 110:1444-1455

106. Huizing M, Carrillo-Carrasco N, Malicdan MC, Noguchi S, Gahl WA, Mitrani-Rosenbaum S, Argov Z, Nishino I (2014) GNE myopathy: new name and new mutation nomenclature. Neuromuscul Disord 24:387-389

107. Harazi A, Becker-Cohen M, Zer H, Moshel O, Hinderlich S, Mitrani-Rosenbaum S (2017) The interaction of UDP- $N$-acetylglucosamine 2-epimerase/ $N$-acetylmannosamine kinase (GNE) and $\alpha$-actinin 2 is altered in GNE myopathy M743T mutant. Mol Neurobiol 54:2928-2938

108. Goicoechea SM, Arneman D, Otey CA (2008) The role of palladin in actin organization and cell motility. Eur J Cell Biol $87: 517-525$

109. Rönty M, Taivainen A, Moza M, Otey CA, Carpen O (2004) Molecular analysis of the interaction between palladin and $\alpha$-actinin. FEBS Lett 566:30-34

110. Franzot G, Sjoblom B, Gautel M, Djinovic Carugo K (2005) The crystal structure of the actin binding domain from $\alpha$-actinin in its closed conformation: structural insight into phospholipid regulation of $\alpha$-actinin. J Mol Biol 348:151-165

111. Liu J, Taylor DW, Taylor KA (2004) A 3-D reconstruction of smooth muscle $\alpha$-actinin by CryoEm reveals two different conformations at the actin-binding region. J Mol Biol 338:115-125

112. Kelly DF, Taylor DW, Bakolitsa C, Bobkov AA, Bankston L, Liddington RC, Taylor KA (2006) Structure of the $\alpha$-actinin-vinculin head domain complex determined by cryo-electron microscopy. J Mol Biol 357:562-573
113. Pavalko FM, Otey CA, Simon KO, Burridge K (1991) $\alpha$-actinin: a direct link between actin and integrins. Biochem Soc Trans 19:1065-1069

114. Khurana S, Chakraborty S, Cheng X, Su YT, Kao HY (2011) The actin-binding protein, actinin $\alpha 4$ (ACTN4), is a nuclear receptor coactivator that promotes proliferation of MCF-7 breast cancer cells. J Biol Chem 286:1850-1859

115. Piirainen H, Taura J, Kursula P, Ciruela F, Jaakola VP (2017) Calcium modulates calmodulin/ $\alpha$-actinin 1 interaction with and agonist-dependent internalization of the adenosine $\mathrm{A} 2 \mathrm{~A}$ receptor. Biochim Biophys Acta 1864:674-686

116. Atkinson RA, Joseph C, Dal Piaz F, Birolo L, Stier G, Pucci P, Pastore A (2000) Binding of $\alpha$-actinin to titin: implications for Z-disk assembly. Biochemistry 39:5255-5264

117. Grison M, Merkel U, Kostan J, Djinovic-Carugo K, Rief M (2017) $\alpha$-Actinin/titin interaction: a dynamic and mechanically stable cluster of bonds in the muscle Z-disk. Proc Natl Acad Sci USA 114:1015-1020

118. Tang J, Taylor DW, Taylor KA (2001) The three-dimensional structure of $\alpha$-actinin obtained by cryoelectron microscopy suggests a model for $\mathrm{Ca}^{2+}$-dependent actin binding. J Mol Biol 310:845-858

119. Satrústegui J, Pardo B, Del Arco A (2007) Mitochondrial transporters as novel targets for intracellular calcium signaling. Physiol Rev 87:29-67

120. Yang Q, Bruschweiler S, Chou JJ (2014) Purification, crystallization and preliminary $\mathrm{X}$-ray diffraction of the $\mathrm{N}$-terminal calmodulin-like domain of the human mitochondrial ATP-Mg/ Pi carrier SCaMC1. Acta Crystallogr Sect F Struct Biol Commun 70:68-71

121. Yang Q, Bruschweiler S, Chou JJ (2014) A self-sequestered calmodulin-like $\mathrm{Ca}^{2+}$ sensor of mitochondrial SCaMC carrier and its implication to $\mathrm{Ca}^{2+}$-dependent ATP-Mg/P(i) transport. Structure 22:209-217

122. Lorenz A, Lorenz M, Vothknecht UC, Niopek-Witz S, Neuhaus HE, Haferkamp I (2015) In vitro analyses of mitochondrial ATP/ phosphate carriers from Arabidopsis thaliana revealed unexpected $\mathrm{Ca}^{2+}$-effects. BMC Plant Biol 15:238

123. Bornstein P, Armstrong LC, Hankenson KD, Kyriakides TR, Yang Z (2000) Thrombospondin 2, a matricellular protein with diverse functions. Matrix Biol 19:557-568

124. Chen H, Herndon ME, Lawler J (2000) The cell biology of thrombospondin-1. Matrix Biol 19:597-614

125. Acharya C, Yik JH, Kishore A, Van Dinh V, Di Cesare PE, Haudenschild DR (2014) Cartilage oligomeric matrix protein and its binding partners in the cartilage extracellular matrix: interaction, regulation and role in chondrogenesis. Matrix Biol 37:102-111

126. Briggs MD, Hoffman SM, King LM, Olsen AS, Mohrenweiser H, Leroy JG, Mortier GR, Rimoin DL, Lachman RS, Gaines ES et al (1995) Pseudoachondroplasia and multiple epiphyseal dysplasia due to mutations in the cartilage oligomeric matrix protein gene. Nat Genet 10:330-336

127. Cohn DH, Briggs MD, King LM, Rimoin DL, Wilcox WR, Lachman RS, Knowlton RG (1996) Mutations in the cartilage oligomeric matrix protein (COMP) gene in pseudoachondroplasia and multiple epiphyseal dysplasia. Ann N Y Acad Sci 785:188-194

128. Susic S, McGrory J, Ahier J, Cole WG (1997) Multiple epiphyseal dysplasia and pseudoachondroplasia due to novel mutations in the calmodulin-like repeats of cartilage oligomeric matrix protein. Clin Genet 51:219-224

129. Yusuf NA, Green JL, Wall RJ, Knuepfer E, Moon RW, SchulteHuxel C, Stanway RR, Martin SR, Howell SA, Douse CH, Cota E, Tate EW, Tewari R, Holder AA (2015) The plasmodium class XIV myosin, MyoB, has a distinct subcellular location in 
invasive and motile stages of the malaria parasite and an unusual light chain. J Biol Chem 290:12147-12164

130. Jo CH, Son J, Kim S, Oda T, Kim J, Lee MR, Sato M, Kim HT, Unzai S, Park SY, Hwang KY (2017) Structural insights into a 20.8-kDa tegumental-allergen-like (TAL) protein from Clonorchis sinensis. Sci Rep 7:1764

131. Santa-Coloma TA, Grasso P, Reichert LE Jr (1992) Synthetic human follicle-stimulating hormone- $\beta$-(1-15) peptide-amide binds $\mathrm{Ca}^{2+}$ and possesses sequence similarity to calcium binding sites of calmodulin. Endocrinology 130:1103-1107

132. Benaim G, Zurini M, Carafoli E (1984) Different conformational states of the purified $\mathrm{Ca}^{2+}$-ATPase of the erythrocyte plasma membrane revealed by controlled trypsin proteolysis. J Biol Chem 259:8471-8477

133. Wang KK, Roufogalis BD, Villalobo A (1989) Calpain I activates $\mathrm{Ca}^{2+}$ transport by the reconstituted erythrocyte $\mathrm{Ca}^{2+}$ pump. $\mathrm{J}$ Membr Biol 112:233-245

134. Hogan PG, Chen L, Nardone J, Rao A (2003) Transcriptional regulation by calcium, calcineurin, and NFAT. Genes Dev 17:2205-2232

135. Li H, Rao A, Hogan PG (2011) Interaction of calcineurin with substrates and targeting proteins. Trends Cell Biol 21:91-103

136. Klee CB, Ren H, Wang X (1998) Regulation of the calmodulin stimulated protein phosphatase, calcineurin. J Biol Chem 273:13367-13370

137. Rusnak F, Mertz P (2000) Calcineurin: form and function. Physiol Rev 80:1483-1521

138. Anglister J, Grzesiek S, Wang AC, Ren H, Klee CB, Bax A (1994) $1 \mathrm{H}, 13 \mathrm{C}, 15 \mathrm{~N}$ nuclear magnetic resonance backbone assignments and secondary structure of human calcineurin B. Biochemistry 33:3540-3547

139. Shi Y (2009) Serine/threonine phosphatases: mechanism through structure. Cell 139:468-484

140. Ye Q, Feng Y, Yin Y, Faucher F, Currie MA, Rahman MN, Jin J, Li S, Wei Q, Jia Z (2013) Structural basis of calcineurin activation by calmodulin. Cell Signal 25:2661-2667

141. Chyan CL, Irene D, Lin SM (2017) The recognition of calmodulin to the target sequence of calcineurin-A novel binding mode. Molecules 22:1584

142. Bond R, Ly N, Cyert MS (2017) The unique C terminus of the calcineurin isoform CNA1 confers non-canonical regulation of enzyme activity by $\mathrm{Ca}^{2+}$ and calmodulin. J Biol Chem 292:16709-16721

143. Burroughs SE, Horrocks WD Jr, Ren H, Klee CB (1994) Characterization of the lanthanide ion-binding properties of calcineurin$\mathrm{B}$ using laser-induced luminescence spectroscopy. Biochemistry 33:10428-10436

144. Kakalis LT, Kennedy M, Sikkink R, Rusnak F, Armitage IM (1995) Characterization of the calcium-binding sites of calcineurin B. FEBS Lett 362:55-58

145. Feng B, Stemmer PM (2001) $\mathrm{Ca}^{2+}$ binding site 2 in calcineurin-B modulates calmodulin-dependent calcineurin phosphatase activity. Biochemistry 40:8808-8814

146. Hudmon A, Schulman H (2002) Structure-function of the multifunctional $\mathrm{Ca}^{2+} /$ calmodulin-dependent protein kinase II. Biochem J 364:593-611

147. Wayman GA, Lee YS, Tokumitsu H, Silva AJ, Soderling TR (2008) Calmodulin-kinases: modulators of neuronal development and plasticity. Neuron 59:914-931

148. Meyer T, Hanson PI, Stryer L, Schulman H (1992) Calmodulin trapping by calcium-calmodulin-dependent protein kinase. Science 256:1199-1202

149. Chao LH, Stratton MM, Lee IH, Rosenberg OS, Levitz J, Mandell DJ, Kortemme T, Groves JT, Schulman H, Kuriyan J (2011) A mechanism for tunable autoinhibition in the structure of a human $\mathrm{Ca}^{2+} /$ calmodulin-dependent kinase II holoenzyme. Cell 146:732-745

150. Ye L-H, Kishi H, Nakamura A, Okagaki T, Tanaka T, Oiwa K, Kohama K (1999) Myosin light-chain kinase of smooth muscle stimulates myosin ATPase activity without phosphorylating myosin light chain. Proc Natl Acad Sci USA 96:6666-6671

151. Khapchaev AY, Shirinsky VP (2016) Myosin light chain kinase MYLK1: anatomy, interactions, functions, and regulation. Biochemistry (Mosc) 81:1676-1697

152. Stull JT, Lin PJ, Krueger JK, Trewhella J, Zhi G (1998) Myosin light chain kinase: functional domains and structural motifs. Acta Physiol Scand 164:471-482

153. Dudek SM, Chiang ET, Camp SM, Guo Y, Zhao J, Brown ME, Singleton PA, Wang L, Desai A, Arce FT, Lal R, Van Eyk JE, Imam SZ, Garcia JG (2010) Abl tyrosine kinase phosphorylates nonmuscle myosin light chain kinase to regulate endothelial barrier function. Mol Biol Cell 21:4042-4056

154. Kilimann MW, Zander NF, Kuhn CC, Crabb JW, Meyer HE, Heilmeyer LM Jr (1988) The $\alpha$ and $\beta$ subunits of phosphorylase kinase are homologous: cDNA cloning and primary structure of the $\beta$ subunit. Proc Natl Acad Sci USA 85:9381-9385

155. Dasgupta M, Honeycutt T, Blumenthal DK (1989) The $\gamma$-subunit of skeletal muscle phosphorylase kinase contains two noncontiguous domains that act in concert to bind calmodulin. J Biol Chem 264:17156-17163

156. Heilmeyer LM Jr, Gerschinski AM, Meyer HE, Jennissen HP (1993) Interaction sites on phosphorylase kinase for calmodulin. Mol Cell Biochem 127-128:19-30

157. Zander NF, Meyer HE, Hoffmann-Posorske E, Crabb JW, Heilmeyer LM Jr, Kilimann MW (1988) cDNA cloning and complete primary structure of skeletal muscle phosphorylase kinase ( $\alpha$ subunit). Proc Natl Acad Sci USA 85:2929-2933

158. Rice NA, Nadeau OW, Yang Q, Carlson GM (2002) The calmodulin-binding domain of the catalytic $\gamma$ subunit of phosphorylase kinase interacts with its inhibitory $\alpha$ subunit: evidence for a $\mathrm{Ca}^{2+}$ sensitive network of quaternary interactions. J Biol Chem 277:14681-14687

159. Mayr GW, Heilmeyer LM Jr (1983) Phosphofructokinase is a calmodulin binding protein. FEBS Lett 159:51-57

160. Martin SR, Biekofsky RR, Skinner MA, Guerrini R, Salvadori S, Feeney J, Bayley PM (2004) Interaction of calmodulin with the phosphofructokinase target sequence. FEBS Lett 577:284-288

161. Li XB, Gu JD, Zhou QH (2015) Review of aerobic glycolysis and its key enzymes-new targets for lung cancer therapy. Thorac Cancer 6:17-24

162. Buschmeier B, Meyer HE, Mayr GW (1987) Characterization of the calmodulin-binding sites of muscle phosphofructokinase and comparison with known calmodulin-binding domains. J Biol Chem 262:9454-9462

163. Mayr GW (1984) Interaction of calmodulin with muscle phosphofructokinase. Interplay with metabolic effectors of the enzyme under physiological conditions. Eur J Biochem 143:521-529

164. Martin-Nieto J, Villalobo A (1998) The human epidermal growth factor receptor contains a juxtamembrane calmodulin-binding site. Biochemistry 37:227-236

165. Li H, Villalobo A (2002) Evidence for the direct interaction between calmodulin and the human epidermal growth factor receptor. Biochem J 362:499-505

166. Li H, Ruano MJ, Villalobo A (2004) Endogenous calmodulin interacts with the epidermal growth factor receptor in living cells. FEBS Lett 559:175-180

167. Li H, Panina S, Kaur A, Ruano MJ, Sanchez-Gonzalez P, la Cour JM, Stephan A, Olesen UH, Berchtold MW, Villalobo A (2012) Regulation of the ligand-dependent activation of the 
epidermal growth factor receptor by calmodulin. J Biol Chem 287:3273-3281

168. Stateva SR, Salas V, Benguria A, Cossio I, Anguita E, MartinNieto J, Benaim G, Villalobo A (2015) The activating role of phospho-(Tyr)-calmodulin on the epidermal growth factor receptor. Biochem J 472:195-204

169. Martin-Nieto J, Cusidó-Hita DM, Li H, Benguría A, Villalobo A (2002) Regulation of ErbB receptors by calmodulin. Recent Res Dev Biochem 3:41-58 (ISBN: 81-7736-155-4)

170. Aifa S, Aydin J, Nordvall G, Lundstrom I, Svensson SP, Hermanson O (2005) A basic peptide within the juxtamembrane region is required for EGF receptor dimerization. Exp Cell Res 302:108-114

171. Aifa S, Frikha F, Miled N, Johansen K, Lundstrom I, Svensson SP (2006) Phosphorylation of Thr654 but not Thr669 within the juxtamembrane domain of the EGF receptor inhibits calmodulin binding. Biochem Biophys Res Commun 347:381-387

172. Aifa S, Miled N, Frikha F, Aniba MR, Svensson SP, Rebai A (2006) Electrostatic interactions of peptides flanking the tyrosine kinase domain in the epidermal growth factor receptor provides a model for intracellular dimerization and autophosphorylation. Proteins 62:1036-1043

173. Sánchez-González P, Jellali K, Villalobo A (2010) Calmodulinmediated regulation of the epidermal growth factor receptor. FEBS J 277:327-342

174. Gill GN (1990) Regulation of EGF receptor expression and function. Mol Reprod Dev 27:46-53

175. Arjona D, Bello MJ, Alonso ME, Gonzalez-Gomez P, Lomas J, Aminoso C, Lopez-Marin I, Isla A, De Campos JM, Vaquero J, Gutierrez M, Villalobo A, Rey JA (2004) Molecular analysis of the erbB gene family calmodulin-binding and calmodulin-like domains in astrocytic gliomas. Int J Oncol 25:1489-1494

176. Arjona D, Bello MJ, Alonso ME, Aminoso C, Isla A, De Campos JM, Sarasa JL, Gutierrez M, Villalobo A, Rey JA (2005) Molecular analysis of the EGFR gene in astrocytic gliomas: mRNA expression, quantitative-PCR analysis of non-homogeneous gene amplification and DNA sequence alterations. Neuropathol Appl Neurobiol 31:384-394

177. Fenstermaker RA, Ciesielski MJ, Castiglia GJ (1998) Tandem duplication of the epidermal growth factor receptor tyrosine kinase and calcium internalization domains in A-172 glioma cells. Oncogene 16:3435-3443

178. Ciesielski MJ, Fenstermaker RA (2000) Oncogenic epidermal growth factor receptor mutants with tandem duplication: gene structure and effects on receptor function. Oncogene 19:810-820

179. Rotin D, Margolis B, Mohammadi M, Daly RJ, Daum G, Li N, Fischer EH, Burgess WH, Ullrich A, Schlessinger J (1992) SH2 domains prevent tyrosine dephosphorylation of the EGF receptor: identification of Tyr992 as the high-affinity binding site for SH2 domains of phospholipase C $\gamma$. EMBO J 11:559-567

180. Chang CM, Shu HK, Ravi L, Pelley RJ, Shu H, Kung HJ (1995) A minor tyrosine phosphorylation site located within the CAIN domain plays a critical role in regulating tissue-specific transformation by erbB kinase. J Virol 69:1172-1180

181. Li H, Sanchez-Torres J, Del Carpio A, Salas V, Villalobo A (2004) The ErbB2/Neu/HER2 receptor is a new calmodulinbinding protein. Biochem J 381:257-266

182. White CD, Li Z, Sacks DB (2011) Calmodulin binds HER2 and modulates HER2 signaling. Biochim Biophys Acta 1813:1074-1082

183. McLaughlin S, Smith SO, Hayman MJ, Murray D (2005) An electrostatic engine model for autoinhibition and activation of the epidermal growth factor receptor (EGFR/ErbB) family. J Gen Physiol 126:41-53

184. Citri A, Skaria KB, Yarden Y (2003) The deaf and the dumb: the biology of ErbB-2 and ErbB-3. Exp Cell Res 284:54-65
185. Brandt P, Zurini M, Neve RL, Rhoads RE, Vanaman TC (1988) A C-terminal, calmodulin-like regulatory domain from the plasma membrane $\mathrm{Ca}^{2+}$-pumping ATPase. Proc Natl Acad Sci USA 85:2914-2918

186. Verma AK, Filoteo AG, Stanford DR, Wieben ED, Penniston JT, Strehler EE, Fischer R, Heim R, Vogel G, Mathews S et al (1988) Complete primary structure of a human plasma membrane $\mathrm{Ca}^{2+}$ pump. J Biol Chem 263:14152-14159

187. Caroni P, Zurini M, Clark A, Carafoli E (1983) Further characterization and reconstitution of the purified $\mathrm{Ca}^{2+}$-pumping ATPase of heart sarcolemma. J Biol Chem 258:7305-7310

188. Zurini M, Krebs J, Penniston JT, Carafoli E (1984) Controlled proteolysis of the purified $\mathrm{Ca}^{2+}$-ATPase of the erythrocyte membrane. A correlation between the structure and the function of the enzyme. J Biol Chem 259:618-627

189. Benaim G, Clark A, Carafoli E (1986) ATPase activity and $\mathrm{Ca}^{2+}$ transport by reconstituted tryptic fragments of the $\mathrm{Ca}^{2+}$ pump of the erythrocyte plasma membrane. Cell Calcium 7:175-186

190. Wang KK, Villalobo A, Roufogalis BD (1992) The plasma membrane calcium pump: a multiregulated transporter. Trends Cell Biol 2:46-52

191. Köster S, Pavkov-Keller T, Kuhlbrandt W, Yildiz O (2011) Structure of human $\mathrm{Na}^{+} / \mathrm{H}^{+}$exchanger NHE1 regulatory region in complex with calmodulin and $\mathrm{Ca}^{2+}$. J Biol Chem 286:40954-40961

192. Wakabayashi S, Bertrand B, Ikeda T, Pouyssegur J, Shigekawa $\mathrm{M}$ (1994) Mutation of calmodulin-binding site renders the $\mathrm{Na}^{+} /$ $\mathrm{H}^{+}$exchanger (NHE1) highly $\mathrm{H}^{+}$-sensitive and $\mathrm{Ca}^{2+}$ regulationdefective. J Biol Chem 269:13710-13715

193. Li X, Ding J, Liu Y, Brix BJ, Fliegel L (2004) Functional analysis of acidic amino acids in the cytosolic tail of the $\mathrm{Na}^{+} / \mathrm{H}^{+}$ exchanger. Biochemistry 43:16477-16486

194. Mebratu YA, Leyva-Baca I, Wathelet MG, Lacey N, Chand HS, Choi AMK, Tesfaigzi Y (2017) Bik reduces hyperplastic cells by increasing Bak and activating DAPk1 to juxtapose ER and mitochondria. Nat Commun 8:803

195. Barroso MR, Bernd KK, DeWitt ND, Chang A, Mills K, Sztul ES (1996) A novel $\mathrm{Ca}^{2+}$-binding protein, p22, is required for constitutive membrane traffic. J Biol Chem 271:10183-10187

196. Naik UP, Patel PM, Parise LV (1997) Identification of a novel calcium-binding protein that interacts with the integrin $\alpha$ IIb cytoplasmic domain. J Biol Chem 272:4651-4654

197. Timm S, Titus B, Bernd K, Barroso M (1999) The EF-hand $\mathrm{Ca}^{2+}$-binding protein p22 associates with microtubules in an N-myristoylation-dependent manner. Mol Biol Cell 10:3473-3488

198. DeFalco TA, Bender KW, Snedden WA (2009) Breaking the code: $\mathrm{Ca}^{2+}$ sensors in plant signalling. Biochem J 425:27-40

199. Patel S, Joseph SK, Thomas AP (1999) Molecular properties of inositol 1,4,5-trisphosphate receptors. Cell Calcium 25:247-264

200. Tang W, Sencer S, Hamilton SL (2002) Calmodulin modulation of proteins involved in excitation-contraction coupling. Front Biosci 7:d1583-d1589

201. Zhu J, Feng Q, Stathopulos PB (2017) The STIM-Orai pathway: STIM-Orai structures: isolated and in complex. Adv Exp Med Biol 993:15-38

202. Thiel G, Rubil S, Lesch A, Guethlein LA, Rossler OG (2017) Transient receptor potential TRPM3 channels: pharmacology, signaling, and biological functions. Pharmacol Res 124:92-99

203. Zhu MX (2005) Multiple roles of calmodulin and other $\mathrm{Ca}^{2+}$-binding proteins in the functional regulation of TRP channels. Pflugers Arch 451:105-115

204. Pankratov Y, Lalo U (2014) Calcium permeability of ligandgated $\mathrm{Ca}^{2+}$ channels. Eur J Pharmacol 739:60-73 
205. Neely A, Hidalgo P (2014) Structure-function of proteins interacting with the $\alpha 1$ pore-forming subunit of high-voltage-activated calcium channels. Front Physiol 5:209

206. Abriel H, Kass RS (2005) Regulation of the voltage-gated cardiac sodium channel Nav1.5 by interacting proteins. Trends Cardiovasc Med 15:35-40

207. Marionneau C, Abriel H (2015) Regulation of the cardiac $\mathrm{Na}^{+}$ channel NaV1.5 by post-translational modifications. J Mol Cell Cardiol 82:36-47

208. Marques-Carvalho MJ, Oppermann J, Munoz E, Fernandes AS, Gabant G, Cadene M, Heinemann SH, Schonherr R, Morais-Cabral JH (2016) Molecular insights into the mechanism of calmodulin inhibition of the EAG1 potassium channel. Structure 24:1742-1754

209. Sachyani D, Dvir M, Strulovich R, Tria G, Tobelaim W, Peretz A, Pongs O, Svergun D, Attali B, Hirsch JA (2014) Structural basis of a Kv7.1 potassium channel gating module: studies of the intracellular C-terminal domain in complex with calmodulin. Structure 22:1582-1594

210. Kohler R (2010) Single-nucleotide polymorphisms in vascular $\mathrm{Ca}^{2+}$-activated $\mathrm{K}^{+}$-channel genes and cardiovascular disease. Pflugers Arch 460:343-351

211. Yang T, Colecraft HM (2016) Calmodulin regulation of TMEM16A and 16B Ca ${ }^{2+}$-activated chloride channels. Channels (Austin) 10:38-44

212. Hanna RA, Campbell RL, Davies PL (2008) Calcium-bound structure of calpain and its mechanism of inhibition by calpastatin. Nature 456:409-412

213. de Ribeiro EA, Pinotsis N, Ghisleni A, Salmazo A, Konarev PV, Kostan J, Sjoblom B, Schreiner C, Polyansky AA, Gkougkoulia EA, Holt MR, Aachmann FL, Zagrovic B, Bordignon E, Pirker KF, Svergun DI, Gautel M, Djinovic-Carugo K (2014) The structure and regulation of human muscle $\alpha$-actinin. Cell 159:1447-1460

214. Galkin VE, Orlova A, Salmazo A, Djinovic-Carugo K, Egelman EH (2010) Opening of tandem calponin homology domains regulates their affinity for F-actin. Nat Struct Mol Biol 17:614-616

215. Kissinger CR, Parge HE, Knighton DR, Lewis CT, Pelletier LA, Tempczyk A, Kalish VJ, Tucker KD, Showalter RE, Moomaw EW et al (1995) Crystal structures of human calcineurin and the human FKBP12-FK506-calcineurin complex. Nature 378:641-644

216. Chattopadhyaya R, Meador WE, Means AR, Quiocho FA (1992) Calmodulin structure refined at 1.7 A resolution. J Mol Biol 228:1177-1192

217. Di Leva F, Domi T, Fedrizzi L, Lim D, Carafoli E (2008) The plasma membrane $\mathrm{Ca}^{2+}$ ATPase of animal cells: structure, function and regulation. Arch Biochem Biophys 476:65-74

218. Harper JF, Binder BM, Sussman MR (1993) Calcium and lipid regulation of an Arabidopsis protein kinase expressed in Escherichia coli. Biochemistry 32:3282-3290

219. Li JL, Baker DA, Cox LS (2000) Sexual stage-specific expression of a third calcium-dependent protein kinase from Plasmodium falciparum. Biochim Biophys Acta 1491:341-349

220. Kieschnick H, Wakefield T, Narducci CA, Beckers C (2001) Toxoplasma gondii attachment to host cells is regulated by a calmodulin-like domain protein kinase. J Biol Chem 276:12369-12377

221. Backman L (2018) $\alpha$-actinin of the chlorarchiniophyte Bigelowiella natans. PeerJ 6:e4288

222. Millake DB, Blanchard AD, Patel B, Critchley DR (1989) The cDNA sequence of a human placental $\alpha$-actinin. Nucleic Acids Res 17:6725

223. del Arco A, Satrustegui J (2004) Identification of a novel human subfamily of mitochondrial carriers with calcium-binding domains. J Biol Chem 279:24701-24713
224. Kuno T, Tanaka H, Mukai H, Chang CD, Hiraga K, Miyakawa T, Tanaka C (1991) cDNA cloning of a calcineurin B homolog in Saccharomyces cerevisiae. Biochem Biophys Res Commun 180:1159-1163

225. Guerini D, Krinks MH, Sikela JM, Hahn WE, Klee CB (1989) Isolation and sequence of a cDNA clone for human calcineurin $\mathrm{B}$, the $\mathrm{Ca}^{2+}$-binding subunit of the $\mathrm{Ca}^{2+} /$ calmodulin-stimulated protein phosphatase. DNA 8:675-682

226. Emori Y, Saigo K (1994) Calpain localization changes in coordination with actin-related cytoskeletal changes during early embryonic development of Drosophila. J Biol Chem 269:25137-25142

227. Aoki K, Imajoh S, Ohno S, Emori Y, Koike M, Kosaki G, Suzuki $\mathrm{K}$ (1986) Complete amino acid sequence of the large subunit of the low-Ca2 +-requiring form of human $\mathrm{Ca} 2+$-activated neutral protease $(\mu \mathrm{CANP})$ deduced from its cDNA sequence. FEBS Lett 205:313-317

228. Imajoh S, Aoki K, Ohno S, Emori Y, Kawasaki H, Sugihara H, Suzuki K (1988) Molecular cloning of the cDNA for the large subunit of the high-Ca ${ }^{2+}$-requiring form of human $\mathrm{Ca}^{2+}$-activated neutral protease. Biochemistry 27:8122-8128

229. Richard I, Broux O, Allamand V, Fougerousse F, Chiannilkulchai N, Bourg N, Brenguier L, Devaud C, Pasturaud P, Roudaut C et al (1995) Mutations in the proteolytic enzyme calpain 3 cause limb-girdle muscular dystrophy type 2A. Cell 81:27-40

230. Newton G, Weremowicz S, Morton CC, Copeland NG, Gilbert DJ, Jenkins NA, Lawler J (1994) Characterization of human and mouse cartilage oligomeric matrix protein. Genomics $24: 435-439$

231. Lehn DA, Brown LJ, Simonson GD, Moran SM, MacDonald MJ (1994) The sequence of a human mitochondrial glycerol3-phosphate dehydrogenase-encoding cDNA. Gene 150:417-418

232. Wernimont AK, Artz JD, Finerty P Jr, Lin YH, Amani M, AllaliHassani A, Senisterra G, Vedadi M, Tempel W, Mackenzie F, Chau I, Lourido S, Sibley LD, Hui R (2010) Structures of apicomplexan calcium-dependent protein kinases reveal mechanism of activation by calcium. Nat Struct Mol Biol 17:596-601

233. Davletova S, Meszaros T, Miskolczi P, Oberschall A, Torok K, Magyar Z, Dudits D, Deak M (2001) Auxin and heat shock activation of a novel member of the calmodulin like domain protein kinase gene family in cultured alfalfa cells. J Exp Bot 52:215-221

234. Pettko-Szandtner A, Meszaros T, Horvath GV, Bako L, CsordasToth E, Blastyak A, Zhiponova M, Miskolczi P, Dudits D (2006) Activation of an alfalfa cyclin-dependent kinase inhibitor by calmodulin-like domain protein kinase. Plant J 46:111-123

235. Dudits D, Abraham E, Miskolczi P, Ayaydin F, Bilgin M, Horvath GV (2011) Cell-cycle control as a target for calcium, hormonal and developmental signals: the role of phosphorylation in the retinoblastoma-centred pathway. Ann Bot 107:1193-1202

236. Li J, Lee YR, Assmann SM (1998) Guard cells possess a calcium-dependent protein kinase that phosphorylates the KAT1 potassium channel. Plant Physiol 116:785-795

237. Mori IC, Muto S (1997) Abscisic acid activates a 48-kDa protein kinase in guard cell protoplasts. Plant Physiol 113:833-839

238. Farmer PK, Choi JH (1999) Calcium and phospholipid activation of a recombinant calcium-dependent protein kinase (DcCPK1) from carrot (Daucus carota L.). Biochim Biophys Acta 1434:6-17

239. Suen KL, Choi JH (1991) Isolation and sequence analysis of a cDNA clone for a carrot calcium-dependent protein kinase: homology to calcium/calmodulin-dependent protein kinases and to calmodulin. Plant Mol Biol 17:581-590

240. Lindzen E, Choi JH (1995) A carrot cDNA encoding an atypical protein kinase homologous to plant calcium-dependent protein kinases. Plant Mol Biol 28:785-797 
241. Prakash SRS, Jayabaskaran C (2006) Heterologous expression and biochemical characterization of two calcium-dependent protein kinase isoforms CaCPK1 and CaCPK2 from chickpea. J Plant Physiol 163:1083-1093

242. Camoni L, Fullone MR, Marra M, Aducci P (1998) The plasma membrane $\mathrm{H}^{+}$-ATPase from maize roots is phosphorylated in the $\mathrm{C}$-terminal domain by a calcium-dependent protein kinase. Physiol Plant 104:549-555

243. Allwood EG, Smertenko AP, Hussey PJ (2001) Phosphorylation of plant actin-depolymerising factor by calmodulin-like domain protein kinase. FEBS Lett 499:97-100

244. Szczegielniak J, Liwosz A, Jurkowski I, Loog M, Dobrowolska G, Ek P, Harmon AC, Muszynska G (2000) Calcium-dependent protein kinase from maize seedlings activated by phospholipids. Eur J Biochem 267:3818-3827

245. Szczegielniak J, Klimecka M, Liwosz A, Ciesielski A, Kaczanowski S, Dobrowolska G, Harmon AC, Muszynska G (2005) A wound-responsive and phospholipid-regulated maize calciumdependent protein kinase. Plant Physiol 139:1970-1983

246. Takezawa D, Patil S, Bhatia A, Poovaiah BW (1996) Calciumdependent protein kinase genes in corn roots. J Plant Physiol 149:329-335

247. Kumar KG, Ullanat R, Jayabaskaran C (2004) Molecular cloning, characterization, tissue-specific and phytohormone-induced expression of calcium-dependent protein kinase gene in cucumber (Cucumis sativus L.). J Plant Physiol 161:1061-1071

248. Lu B, Ding R, Zhang L, Yu X, Huang B, Chen W (2006) Molecular cloning and characterization of a novel calcium-dependent protein kinase gene IiCPK2 responsive to polyploidy from tetraploid Isatis indigotica. J Biochem Mol Biol 39:607-617

249. Guenther JF, Roberts DM (2000) Water-selective and multifunctional aquaporins from Lotus japonicus nodules. Planta 210:741-748

250. Binder BM, Harper JF, Sussman MR (1994) Characterization of an Arabidopsis calmodulin-like domain protein kinase purified from Escherichia coli using an affinity sandwich technique. Biochemistry 33:2033-2041

251. Hrabak EM, Dickmann LJ, Satterlee JS, Sussman MR (1996) Characterization of eight new members of the calmodulin-like domain protein kinase gene family from Arabidopsis thaliana. Plant Mol Biol 31:405-412

252. Xing T, Wang XJ, Malik K, Miki BL (2001) Ectopic expression of an Arabidopsis calmodulin-like domain protein kinaseenhanced NADPH oxidase activity and oxidative burst in tomato protoplasts. Mol Plant Microbe Interact 14:1261-1264

253. Krysan PJ, Young JC, Tax F, Sussman MR (1996) Identification of transferred DNA insertions within Arabidopsis genes involved in signal transduction and ion transport. Proc Natl Acad Sci USA 93:8145-8150

254. Yoon GM, Dowd PE, Gilroy S, McCubbin AG (2006) Calciumdependent protein kinase isoforms in Petunia have distinct functions in pollen tube growth, including regulating polarity. Plant Cell 18:867-878

255. Rudd JJ, Franklin F, Lord JM, Franklin-Tong VE (1996) Increased phosphorylation of a $26-\mathrm{kD}$ pollen protein is induced by the self-incompatibility response in Papaver rhoeas. Plant Cell 8:713-724

256. Lakatos L, Hutvagner G, Banfalvi Z (1998) Potato protein kinase StCPK1: a putative evolutionary link between CDPKs and CRKs. Biochim Biophys Acta 1442:101-108

257. Yoo BC, Lee JY, Lucas WJ (2002) Analysis of the complexity of protein kinases within the phloem sieve tube system. Characterization of Cucurbita maxima calmodulin-like domain protein kinase 1. J Biol Chem 277:15325-15332

258. Asano T, Kunieda N, Omura Y, Ibe H, Kawasaki T, Takano M, Sato M, Furuhashi H, Mujin T, Takaiwa F, Wu Cy CY, Tada
Y, Satozawa T, Sakamoto M, Shimada H (2002) Rice SPK, a calmodulin-like domain protein kinase, is required for storage product accumulation during seed development: phosphorylation of sucrose synthase is a possible factor. Plant Cell 14:619-628

259. Shimada H, Koishihara H, Saito Y, Arashima Y, Furukawa T, Hayashi H (2004) A rice antisense SPK transformant that lacks the accumulation of seed storage substances shows no correlation between sucrose concentration in phloem sap and demand for carbon sources in the sink organs. Plant Cell Physiol 45:1105-1109

260. Lee JW, Zhang Y, Weaver CD, Shomer NH, Louis CF, Roberts DM (1995) Phosphorylation of nodulin 26 on serine 262 affects its voltage-sensitive channel activity in planar lipid bilayers. J Biol Chem 270:27051-27057

261. Douglas P, Moorhead G, Hong Y, Morrice N, MacKintosh C (1998) Purification of a nitrate reductase kinase from Spinacia oleracea leaves, and its identification as a calmodulin-domain protein kinase. Planta 206:435-442

262. Huang JZ, Huber SC (2001) Phosphorylation of synthetic peptides by a CDPK and plant SNF1-related protein kinase. Influence of proline and basic amino acid residues at selected positions. Plant Cell Physiol 42:1079-1087

263. Llop-Tous I, Dominguez-Puigjaner E, Vendrell M (2002) Characterization of a strawberry cDNA clone homologous to calciumdependent protein kinases that is expressed during fruit ripening and affected by low temperature. J Exp Bot 53:2283-2285

264. Lino B, Baizabal-Aguirre VM, Gonzalez de la Vara LE (1998) The plasma-membrane $\mathrm{H}^{+}$-ATPase from beet root is inhibited by a calcium-dependent phosphorylation. Planta 204:352-359

265. Yoon GM, Cho HS, Ha HJ, Liu JR, Lee HS (1999) Characterization of NtCDPK1, a calcium-dependent protein kinase gene in Nicotiana tabacum, and the activity of its encoded protein. Plant Mol Biol 39:991-1001

266. Rutschmann F, Stalder U, Piotrowski M, Oecking C, Schaller A (2002) LeCPK1, a calcium-dependent protein kinase from tomato. Plasma membrane targeting and biochemical characterization. Plant Physiol 129:156-168

267. Chang W, Fu G, Chen X, Zhu J, Zhang Z (2011) Biochemical characterization of a calcium-sensitive protein kinase LeCPK2 from tomato. Indian J Biochem Biophys 48:148-153

268. Chang WJ, Su HS, Li WJ, Zhang ZL (2009) Expression profiling of a novel calcium-dependent protein kinase gene, LeCPK2, from tomato (Solanum lycopersicum) under heat and pathogen-related hormones. Biosci Biotechnol Biochem 73:2427-2431

269. Leclercq J, Ranty B, Sanchez-Ballesta MT, Li Z, Jones B, Jauneau A, Pech JC, Latche A, Ranjeva R, Bouzayen M (2005) Molecular and biochemical characterization of LeCRK1, a ripening-associated tomato CDPK-related kinase. J Exp Bot 56:25-35

270. Martinez-Noël G, Nagaraj VJ, Calo G, Wiemken A, Pontis HG (2007) Sucrose regulated expression of $\mathrm{a} \mathrm{Ca}^{2+}$-dependent protein kinase (TaCDPK1) gene in excised leaves of wheat. Plant Physiol Biochem 45:410-419

271. Ganguly S, Singh M (1998) Characterization of a second calcium-dependent protein kinase from winged bean. Phytochemistry 48:61-70

272. Ganguly S, Singh M (1999) Purification and characterization of a protein phosphatase from winged bean. Phytochemistry 52:239-246

273. Iyer GR, Singh S, Kaur I, Agarwal S, Siddiqui MA, Bansal A, Kumar G, Saini E, Paul G, Mohmmed A, Chitnis CE, Malhotra P (2018) Calcium-dependent phosphorylation of Plasmodium falciparum serine repeat antigen 5 triggers merozoite egress. $\mathbf{J}$ Biol Chem 293:9736-9746

274. Bansal A, Singh S, More KR, Hans D, Nangalia K, Yogavel M, Sharma A, Chitnis CE (2013) Characterization of Plasmodium falciparum calcium-dependent protein kinase 1 (PfCDPK1) and 
its role in microneme secretion during erythrocyte invasion. $\mathrm{J}$ Biol Chem 288:1590-1602

275. Cavagnino A, Rossi F, Rizzi M (2011) The potent antiplasmodial calmodulin-antagonist trifluoperazine inhibits plasmodium falciparum calcium-dependent protein kinase 4. Protein Pept Lett 18:1273-1279

276. Billker O, Dechamps S, Tewari R, Wenig G, Franke-Fayard B, Brinkmann V (2004) Calcium and a calcium-dependent protein kinase regulate gamete formation and mosquito transmission in a malaria parasite. Cell 117:503-514

277. Sugi T, Kato K, Kobayashi K, Pandey K, Takemae H, Kurokawa H, Tohya Y, Akashi H (2009) Molecular analyses of Toxoplasma gondii calmodulin-like domain protein kinase isoform 3. Parasitol Int 58:416-423
278. Bennett MK, Kennedy MB (1987) Deduced primary structure of the $\beta$ subunit of brain type II $\mathrm{Ca}^{2+} /$ calmodulin-dependent protein kinase determined by molecular cloning. Proc Natl Acad Sci USA 84:1794-1798

279. Takio K, Blumenthal DK, Walsh KA, Titani K, Krebs EG (1986) Amino acid sequence of rabbit skeletal muscle myosin light chain kinase. Biochemistry 25:8049-8057

280. Reimann EM, Titani K, Ericsson LH, Wade RD, Fischer EH, Walsh KA (1984) Homology of the $\gamma$ subunit of phosphorylase b kinase with cAMP-dependent protein kinase. Biochemistry $23: 4185-4192$

Publisher's Note Springer Nature remains neutral with regard to jurisdictional claims in published maps and institutional affiliations. 